\title{
WestVirginiaUniversity
}

THE RESEARCH REPOSITORY @ WVU

Graduate Theses, Dissertations, and Problem Reports

1998

\section{Do Christian schools implement long -range plans?}

Steven L. DeGeorge

West Virginia University

Follow this and additional works at: https://researchrepository.wvu.edu/etd

\section{Recommended Citation}

DeGeorge, Steven L., "Do Christian schools implement long -range plans?" (1998). Graduate Theses, Dissertations, and Problem Reports. 3144.

https://researchrepository.wvu.edu/etd/3144

This Dissertation is protected by copyright and/or related rights. It has been brought to you by the The Research Repository @ WVU with permission from the rights-holder(s). You are free to use this Dissertation in any way that is permitted by the copyright and related rights legislation that applies to your use. For other uses you must obtain permission from the rights-holder(s) directly, unless additional rights are indicated by a Creative Commons license in the record and/ or on the work itself. This Dissertation has been accepted for inclusion in WVU Graduate Theses, Dissertations, and Problem Reports collection by an authorized administrator of The Research Repository @ WVU.

For more information, please contact researchrepository@mail.wvu.edu. 


\title{
DO CHRISTIAN SCHOOLS
}

\section{IMPLEMENT LONG-RANGE PLANS?}

\author{
DISSERTATION
}

Submitted To The College of

Human Resources and Education

of

West Virginia University

In Partial Fulfillment of the Requirements of the Degree of Doctor of Education

By

Steven L. DeGeorge

Morgantown

West Virginia

July 1998 


\section{ACKNOWLEDGMENTS}

I would like to thank Dr. James A. Martin for taking me through this process and encouraging me to finish. Thanks also to Dr. Ernest R. Goeres for stepping in late in the game as chair of my committee.

I want to express my appreciation to the Association of Christian Schools International for allowing me to conduct the study among schools in that association. I am eternally grateful to the administrators and board chairs of the thirty-two schools in this study.

Special thanks to Luann Stewart, Char Allen, and Pam Cain for their help and encouragement. 


\section{TABLE OF CONTENTS}

Acknowledgments $\ldots \ldots \ldots \ldots \ldots \ldots \ldots \ldots \ldots \ldots \ldots \ldots \ldots \ldots \ldots \ldots \ldots \ldots \ldots \ldots$ Page ii

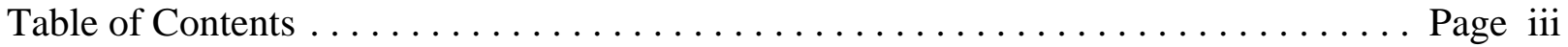

List of Charts and Illustrations $\ldots \ldots \ldots \ldots \ldots \ldots \ldots \ldots \ldots \ldots \ldots \ldots \ldots \ldots \ldots \ldots$

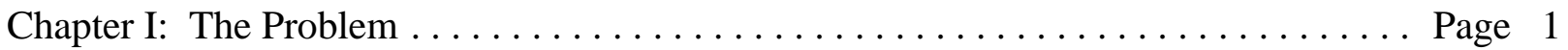

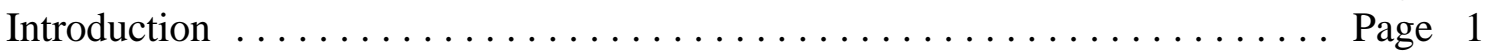

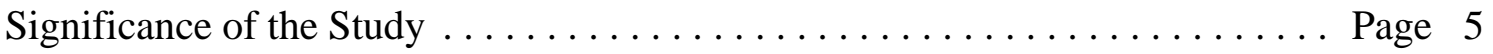

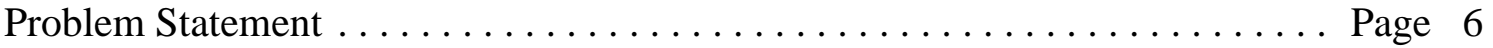

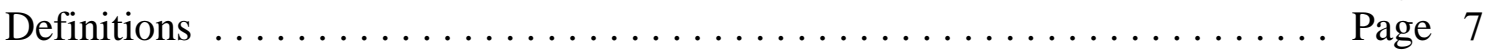

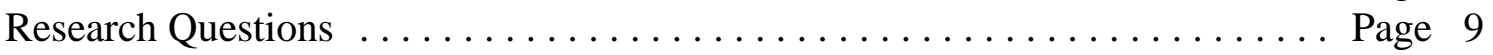

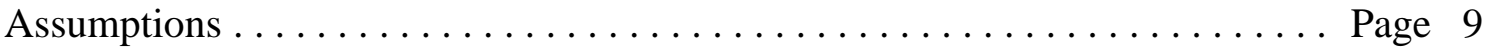

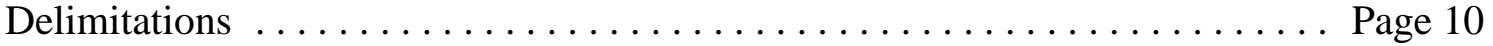

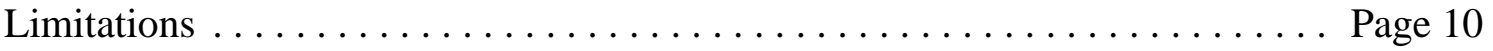

Chapter II: Review of Related Research Literature . . . . . . . . . . . . . . . . Page 12

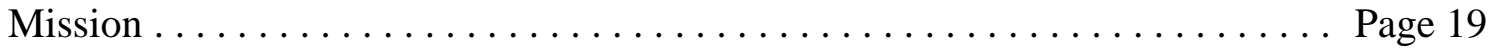

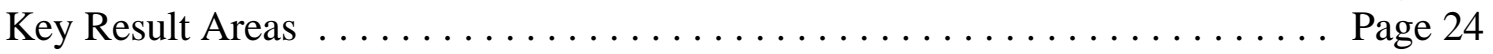

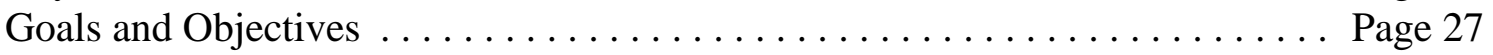

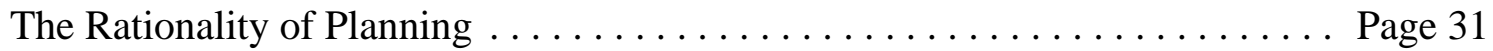

Implementation and Administrative Assessment . . . . . . . . . . . . Page 35

Administrative Leadership . . . . . . . . . . . . . . . . . Page 38

Chapter III: Research Design . . . . . . . . . . . . . . . . . . . Page 40

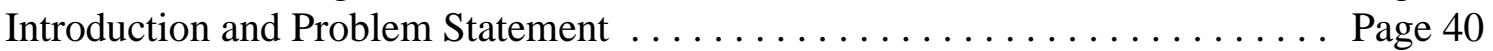

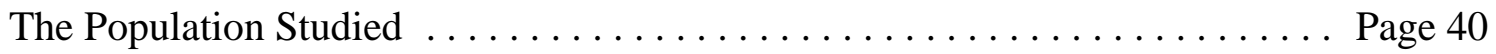

Principal Methods of Research $\ldots \ldots \ldots \ldots \ldots \ldots \ldots$ Page 42

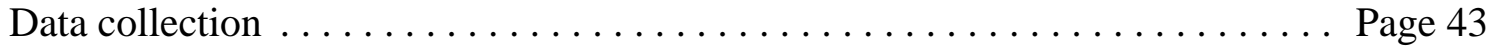

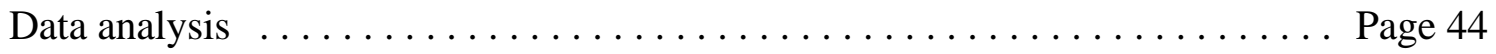

Chapter IV: Results ............................. Page 48

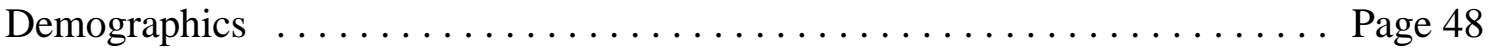

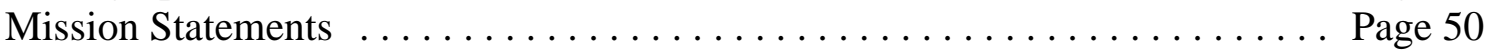

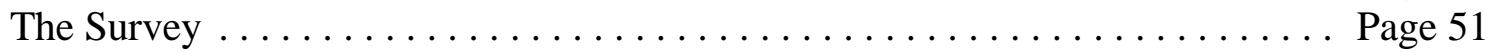

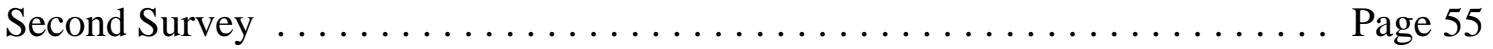

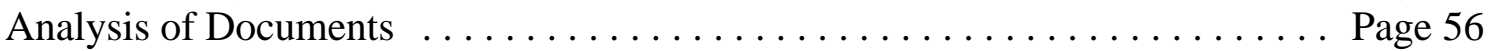

What the Data Suggest . . . . . . . . . . . . . . . . Page 63

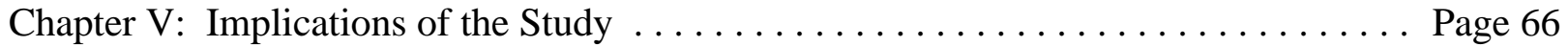

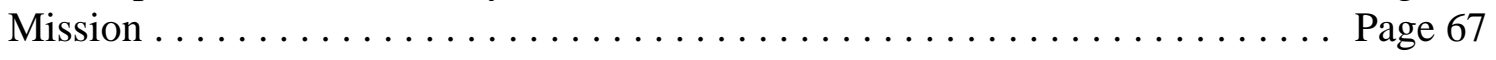


Key Result Areas . . . . . . . . . . . . . . . . . . . . . . . . Page 67

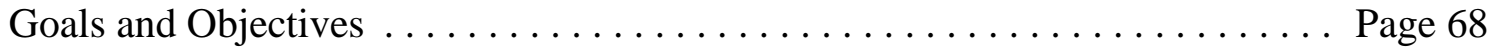

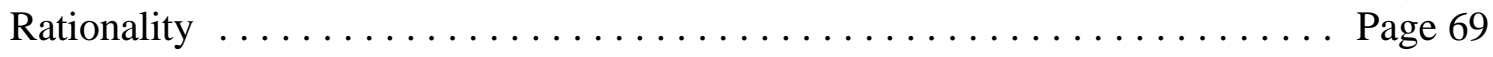

Rationality and Christian Thought $\ldots \ldots \ldots \ldots \ldots \ldots \ldots \ldots \ldots$ Page 70

Implementation and Administrative Assessment . . . . . . . . . . . . Page 71

Administrative Leadership . . . . . . . . . . . . . . . . Page 73

Recommendations to the Profession $\ldots \ldots \ldots \ldots \ldots \ldots \ldots \ldots$ Page 74

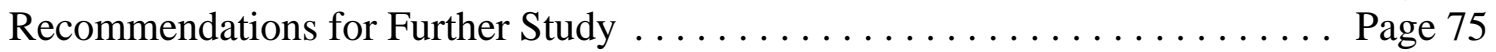

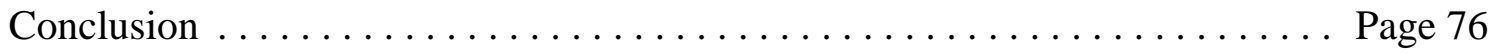

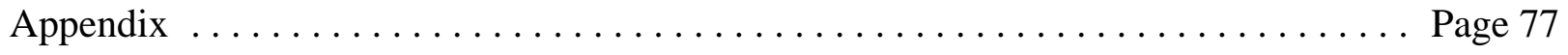

Bibliography $\ldots \ldots \ldots \ldots \ldots \ldots \ldots \ldots \ldots \ldots \ldots \ldots \ldots \ldots \ldots \ldots \ldots \ldots \ldots$ Page 131

Committee Approval . . . . . . . . . . . . . . . . . . . . . . . . Page 141 


\section{LIST OF CHARTS AND ILLUSTRATIONS}

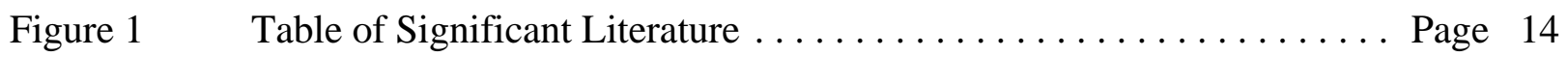

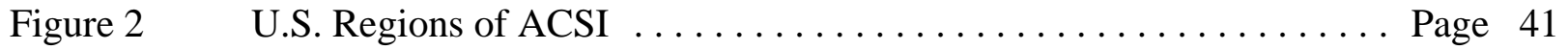

Figure 3 Categories of Respondents ......................... Page 45

Figure $4 \quad$ Grid of Comparative Statements $\ldots \ldots \ldots \ldots \ldots \ldots \ldots \ldots \ldots$ Page 46

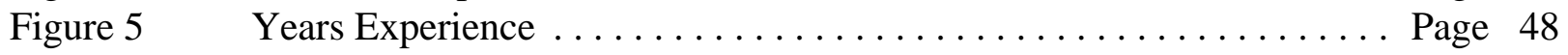

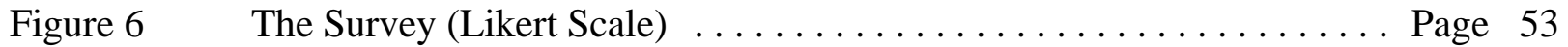

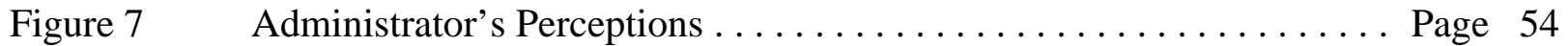

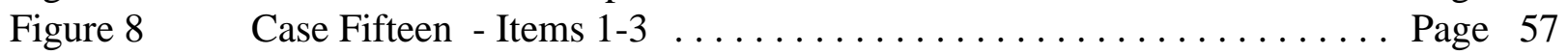

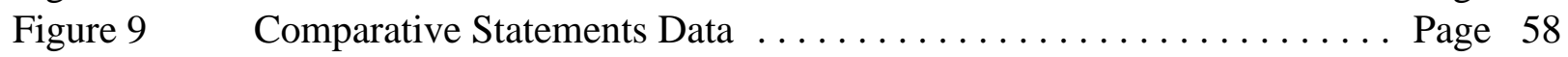

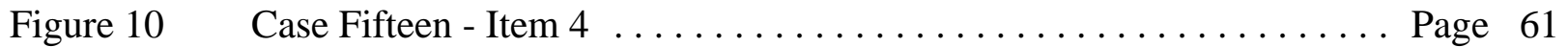

Figure 11 Case Two Evaluation Document ................... Page 62 


\section{CHAPTER I}

\section{The Problem}

\section{Introduction}

There is a proverb that says: "If you aim at nothing you are sure to hit it." Planning is an important part of running any organization including a school. Current trends in education, including the popular idea of site-based management, place a great deal of responsibility for planning at the local school level. As a result, all schools, both public and private, are being asked to invest more time and energy in the development of some kind of plan.

When a school develops its own long-range plan, the implication is that both authority and responsibility become more localized. If the plan reflects the needs and aspirations of all interested parties in that organization, logic would dictate that it is more likely to be implemented successfully. Successful implementation of a well-conceived plan should enhance the effectiveness of the school. Many interesting questions have been raised about planning. Researchers have tried for decades to establish a body of data which might help them discover how, and if, planning affects organizations.

The literature of business management is replete with statements about the nature of planning. Theodore Caplow (1983) in Managing an Organization states:

"Part of the magic of planning is the inevitable discovery of possible courses of action not previously imagined or noticed. The simple procedure of arranging alternatives and contingencies in an orderly way often leads to useful new strategies that would not otherwise have been suggested." (p.183) 
Stone (1987) says that planning is an effort on the part of a school to respond to change rather than resist it. She sees strategy and planning as related:

"Many professional planners see a distinction between strategy and planning: strategy deals with change whereas planning is operational. Good planning depends on good strategy, which directs and defines the plan." (p.4)

Much has been said about how planning relates to effectiveness. Hoy and Miskel (1987) relate organizational effectiveness to goal attainment:

"Goals provide direction and reduce uncertainty for organizational participants and a standard for assessment of the organization." (p.387)

Donsky (1994) describes the relationship between strategic planning, operational planning and measures of institutional effectiveness. He links these related concepts together in his Integrated Effectiveness Planning Model (IEPM):

"The major effect of this model (IEPM) is to take what could be separate processes (planning and effectiveness) and link them together through the college mission statement." (p.3)

In the planning literature there appears to be a standard pattern or outline for a longrange plan that has three components:

1. The statement of mission.

2. Key goals and objectives which are foundational to fulfillment of the mission.

3. A plan for meeting the goals and objectives.

The purpose of this project was to explore one facet of the planning process; implementation. If the leaders of a school agree on the need for a plan, and if they work 
together to develop such a plan then it would seem to follow that they would also work to implement that plan.

The Association of Christian Schools International (ACSI) requires that a five-year plan be shown to the chair of the visiting committee during the accreditation visit (ACSI, 1983). Therefore, ACSI accredited schools are developing plans. The question is, does the planning process end there or are they implementing those plans?

Implementation is a key ingredient of any plan. It is also the component most central to this study. Implementation necessarily includes evaluation of both the plan and the people assigned to carry out the plan. Without this type of follow through it is possible that the plan will not be carried out. For instance, the schools in this study will have prepared a plan in order to be accredited by ACSI. It is possible to prepare such a plan based solely on the extrinsic motivation of the accreditation process or some other motivator and never actually implement the plan.

It is also possible that the administration or the school board have alternative views on the nature and purpose of planning. Such views certainly exist. Aaron Wildavsky (1973) rocked the planning culture with an article entitled: "If Planning is Everything, Then Maybe it's Nothing." Since that time a lot of writers and researchers have speculated on whether planning is a means to an end or an end in itself. If it is an end in itself then formal implementation would be unnecessary.

Consideration has also been given to the impossibility of accounting for all the present and future variables when developing a long-range plan. The bulk of the planning literature 
suggests, however, that while a long-range plan is a dynamic and evolving document which is updated continuously, there is value in a rational "means-end" concept of planning.

Kallman, Reinharth, and Shapiro (1981) talk about this aspect of plans as they relate to the dynamic nature of organizations:

"Planning is a continuing function; it is never finished. The planning process includes many stages - from goal-setting to analysis, to strategy formulation and evaluation, to implementation. Implementation is always followed by feedback and control: that is, the original premises developed are continually tested against reality, and, as reality changes, the planning process must be reinstituted and the premises (and analyses) reworked. In other words, the plan - the result of the planning process - is dynamic, constantly adapting to changes in the internal and the external environment. That is the way it should be, because a static plan would be of no value to a dynamic organization." (p.7)

Simon (1997) in discussing the way that plans are carried out in organizations talks about cooperative behavior among individuals who are involved in implementing a plan:

"Administrative organizations are systems of cooperative behavior. The members of the organization are expected to orient their behavior with respect to certain goals that are taken as 'organization objectives.' This leaves the problem of coordinating their behavior - of providing each one with the knowledge of the behaviors of the others upon which he can base his own decisions. In cooperative systems, even though all participants are agreed on the objectives to be attained, they cannot ordinarily be left to themselves in selecting strategies that will lead to these objectives; for the selection of a correct strategy involves a knowledge of each as to the strategy of the others." (pp.81-82)

Later in the same text:

"The Group Plan. The idea of a plan for the behavior of a group does not involve any metaphysical notions of a 'group mind.' It is a specification as to how a number of persons 
shall behave. The plan has its existence on paper, or in the respective minds of the individuals who create it. These individuals may be many or few; they may belong to the group, or they may not. All that is required is that, before the plan is acted out, it shall be communicated to the group members who are doing the acting." (p. 115)

And again:

"Review enables those who are in a position of authority in the administrative hierarchy to determine what is actually being done by their subordinates. Methods of Review. Review may be extended to the results of the subordinates' activities, measured in terms of their objectives; the tangible products, if there are such, of their activities; or the method of their performance." (pp.314-315 emphasis original)

These statements clearly imply that communication of goals, a group plan and the review process are vital elements in the implementation of organizational goals. This is relevant to this study in that evidence of implementation will be sought in the job descriptions and evaluation documents of administrators.

\section{Significance of the Study}

This study was intended to help clarify whether the interest in the long-range planning process among ACSI accredited schools is superficial or substantive. It raised the issue of whether administrators and boards view planning as a literal or symbolic process. Primarily though, it addresses the question: are schools dealing with or neglecting the concepts of accountability and follow-through inherent to effective implementation of a long-range plan.

This study is significant as it relates to implementation of long-range plans in ACSI accredited schools, but it also relates to the concept of site-based management and the local 
authority/accountability inherent to that concept. Schools which want to achieve local control will need to consider how to achieve their mission and goals. It is important that schools in general, examine what they believe about planning and whether they are acting in a manner which is consistent with those beliefs. ACSI schools were chosen because they are locally controlled and because they are required to have a long-range plan in order to be accredited. There is nothing peculiar or exceptional about the way Christian schools plan or implement plans that would limit the generalizability of this study.

To some degree schools that develop a long-range plan organized in the classic pattern described above are acknowledging the appropriateness of this pattern for planning. However, if the school leadership does not implement its plan, or if it has other standards or methods for achieving progress toward its mission, then why develop the plan? In the same way if a viable long-range plan is in place how can the school's leadership justify not knowing if it is being followed? This study has hopefully shed light on these issues.

\section{Problem Statement}

The problem is to determine if the existence of a long-range plan has a direct influence on the way a school administration actually operates a school. In other words, if there is a long-range plan, is that plan being implemented?

Additional questions addressed include: 1. Do school boards believe enough in longrange planning to require the administration to develop and implement the plan as evidenced in job descriptions, evaluation documents, or other procedures? 2. If school administrators 
and boards do not require the implementation of their plan, could this mean that they do not subscribe to the classic or rational model of planning described above?

\section{Definitions}

For the purposes of this research, the following definitions were used:

ACSI, (Association of Christian Schools International) an organization which serves about 3000 evangelical schools and colleges worldwide with services including curriculum support, legal assistance, testing, in service training, certification and accreditation. International headquarters are in Colorado Springs, Colorado.

administrators, (or school administrators) those employees of an ACSI accredited school which have the responsibility for carrying out the goals and strategies of the school, thereby helping to fulfill its mission. In ACSI schools the chief executive officer of a school is most often referred to as its administrator, although the terms principal, headmaster, and superintendent are also used by some schools. ACSI accredited schools are led by a school board (usually volunteers) which can be either elected or appointed. In virtually all ACSI schools the administrator reports directly to the board or some committee thereof.

board, the governing body of an ACSI school. Boards are elected or appointed, usually from among the school's constituents. The board is responsible to set policies and has both the authority and the responsibility to require implementation of those policies by the administration. 
evaluation documents, any written forms or guidelines used to evaluate the performance of those holding specific positions within the school.

goal, a clear aim of the organization. In this case, goal will be used as an intermediate or incremental aim.

job descriptions, written statements outlining the responsibilities of persons holding a specific position in an ACSI school.

long-range plan, a clearly stated written plan which has its basis in the school's mission statement, identifies key goals and objectives, and sets strategies for meeting them in a three to five year period of time.

mission statement, a concise statement of the operational and philosophical purpose of the organization from which organizational goals are developed.

objective, a clear aim of the organization. In this case, objective will be used as an ultimate or final aim.

other procedures, any method other than job descriptions and evaluation documents used to evaluate the performance of those holding specific positions within the school. These might include surveys, observations, and/or conferences with superordinates. rational model, the model for planning which has as its underlying assumption that planning is a meaningful activity related to determining organizational outcomes. Planning in this model is a means to an end rather than an end in itself. This is significant because it implies that plans must be implemented in order to affect the desired outcomes. This model is also referred to as the classic model because it has three elements, 
common to long-range plans. They are: 1. a mission statement. 2. goals and objectives. 3. a plan, including standards or directives for implementation.

\section{Research Questions}

The study focused on the following questions:

II What percentage of responding ACSI accredited schools have and can identify a longrange plan?

II In the schools that have a long-range plan, are administrators being held accountable by their boards to implement that plan?

II Are there identifiable elements of the long-range plan in job descriptions of administrators?

II Are components of the plan included in the documents used to evaluate administrators?

II Do ACSI school boards hold administrators responsible for carrying out longrange plans?

II What is the correlation between ACSI accreditation and the development of longrange plans?

\section{Assumptions}

Following a review of the research literature it is assumed that a long-range plan, organized in the classic pattern described above is necessary and good for the accomplishment of organizational goals. An additional assumption of this study is that the existence of a long-range plan implies belief in the rational planning model. School boards 
who believe in this model should produce specific objectives for which the school administration shall be held accountable. If those points of accountability are non-existent or unclear, questions can be raised about the viability of the plan and/or the school's values related to planning.

In this project long-range plans will be analyzed to seek evidence of implementation strategies. The researcher accepts the primary assumption that plans have little value if not implemented. Thus evidence of implementation will be sought in documents and processes developed by school boards for evaluating administrators.

\section{Delimitations}

As noted above, the study was conducted among schools accredited by the Association of Christian Schools International. The schools selected for inclusion in this study were schools located in the United States. There are 312 such schools nationwide. Sixty three schools were chosen at random from the total of 312 . That sample represented twenty percent of the population of 312 schools.

Some questions associated with planning which were delimited from this study included:

How was the long-range plan developed? By whom was it developed? What are the comparative perceptions of other stakeholders in the schools in question? 


\section{Limitations}

The most significant limitation of this study is that it was conducted among private Christian schools accredited by one accrediting body. The schools accredited by ACSI are private schools with a great deal of local autonomy. The results of the study will be generalizable to the 312 schools accredited by ACSI. They should also be generalizable to private schools with similar local autonomy. The concept of long-range plan implementation should be generalizable to any school or educational organization which utilizes long-range planning.

Obviously, this study is not meaningful to schools or organizations which do not accept the rational long-range planning model described in this proposal as a guide to planning. This limitation is intentional and is related to the basic assumptions of the study. 


\section{CHAPTER 2}

\section{Review of Related Research and Literature}

Much of the research and literature pertinent to this study was found in research related to business administration and management. Long-range planning is generally accepted in the literature as a technique that has been borrowed from business. Although for the most part schools have a simpler structure in terms of marketing, distribution, resource allocation, ownership scenarios, and profit margins, educators are perceived as viewing longrange planning as a significant transferable concept. This issue is especially pertinent to schools operating in the private sector.

The planning literature from the world of business management seems to focus not so much on whether a company will use long-range planning but on what variations or alternative models of planning will be used. For instance, Goldberg and Sifonis (1994) discuss "business transformation", "strategic alignment modeling". They talk about a "holistic approach" to dynamic planning. Lorange (1981) talks about "corrective measures through planning" and "Quinn's process of logical incrementalism" and the "stages of goal setting". Steiner (1979) mentions "opportunistic planning, adaptive planning, and muddling through". The issues for business are often centered on internal and external analysis techniques and the planning culture (Cleland and King, 1974).

In education, much of the literature examined was concerned with formal planning processes themselves as opposed to other ways to run schools. There is a significant discussion of attitudes among teachers, administrators, and other "stakeholders" toward the planning process (Nessmith, 1992). Several research projects have focused on the "front 
end" planning issues such as the degree to which long-range planning is being used or whether schools are laying the groundwork for long-range planning through consensus building and needs assessment.

One area where business and education have overlapped is the question of how to get the entire organization involved in the planning process. Much has been written about what happens if there is not a "consensus" or a "team spirit" in regard to planning. In schools as well as corporations there are "coalitions" which are part of the informal power structure and can sabotage the planning process if they do not feel that their views are being represented (Caplow, 1983; Desloriers, 1993). Within that context, a project which examines implementation issues should be an appropriate addition to the existing literature. Instead of examining issues related to the beginning of planning, this research concerns itself with the end of planning. The researcher discovered that much of the published research focused on the foundations of planning whereas this research examined one of the structures of planning which are built on that foundation, namely implementation.

Certain attitudes and procedures have been reported as being significant in "creating" a long-range plan. In this project the hope was to discover attitudes and procedures which effect the "implementation" of a long-range plan.

The table below is an enumeration of significant literature related to long-range planning. Six significant issues reported in the literature were reviewed and are discussed in the appropriate sections of this chapter. They are: 1) Mission; 2) Key result areas; 3) Goals and objectives; 4) The rationality of planning; 5) Implementation and administrative assessment; and 6) Leadership. 
Figure 1

Table of

Significant Literature

\begin{tabular}{|c|c|c|c|}
\hline $\begin{array}{c}\text { Author, Title } \\
\text { (alphabetical) }\end{array}$ & $\begin{array}{l}\text { Description } \\
\text { of Work }\end{array}$ & $\begin{array}{l}\text { Value } \\
\text { Rating } \\
\text { 1=Great } \\
\text { 2=Some } \\
\text { 3=Little }\end{array}$ & Focus \\
\hline $\begin{array}{l}\text { Al-Khalaf, Abdullah M. (1994). } \\
\text { "Factors that Affect the Success and } \\
\text { Failure of TQM Implementation in Small } \\
\text { United States Cities." }\end{array}$ & Dissertation & 3 & $\begin{array}{l}\text { High leadership and high } \\
\text { employee input in combination. }\end{array}$ \\
\hline $\begin{array}{l}\text { Baldwin, Mark D. (1994). "Implemen- } \\
\text { tation of Strategic Planning in a Public } \\
\text { School Setting: A Case Study." }\end{array}$ & Dissertation & 2 & $\begin{array}{l}\text { The significance of } \\
\text { "stakeholder" involvement. }\end{array}$ \\
\hline $\begin{array}{l}\text { Bashan, Vickie P. (1989). "A Study of } \\
\text { the Status of Strategic Planning in } \\
\text { Kentucky School Districts." }\end{array}$ & Dissertation & 2 & $\begin{array}{l}\text { If planning is important how } \\
\text { much is being done? }\end{array}$ \\
\hline $\begin{array}{l}\text { Bastin, Mark Fletcher. (1996). "The } \\
\text { Effects of Status, Participation, Coercion, } \\
\text { Knowledge and Time on Maintaining } \\
\text { Consensus-Based Agreement in Planning } \\
\text { Groups (Strategic Planning)." }\end{array}$ & Dissertation & 1 & $\begin{array}{l}\text { The importance of mission in } \\
\text { maintaining implementation of } \\
\text { plans. }\end{array}$ \\
\hline $\begin{array}{l}\text { Brackett, Vivian Sherill Snelling. } \\
\text { (1997). "The South Carolina District } \\
\text { Strategic and School Renewal Planning } \\
\text { Process in Selected Districts and Schools } \\
\text { (Restructuring, School Districts, Site- } \\
\text { Based Management)." }\end{array}$ & Dissertation & 1 & $\begin{array}{l}\text { Two planning models compared } \\
\text { and contrasted - Bill Cook, } \\
\text { SCSDE. Evaluation component } \\
\text { lacking. }\end{array}$ \\
\hline $\begin{array}{l}\text { Brumfield, Jennifer S. (1996). } \\
\text { "Community Members' Perceptions of } \\
\text { the Role of a Deliberative Planning } \\
\text { Process in Their School-Community } \\
\text { (Strategic Planning)." }\end{array}$ & Dissertation & 1 & $\begin{array}{l}\text { Maurice Holts three stages of } \\
\text { decision-making: platform, } \\
\text { deliberations, policy. }\end{array}$ \\
\hline $\begin{array}{l}\text { Burgess, Donald D. (1997). "A } \\
\text { Strategic Ministry Plan for Church } \\
\text { Dynamics International." }\end{array}$ & Dissertation & 3 & Strategic planning. \\
\hline $\begin{array}{l}\text { Busler, Brian Scott. (1992). "The Role } \\
\text { of Strategic Planning and Its Effect on } \\
\text { Decision -Making in Wisconsin Public } \\
\text { Schools." }\end{array}$ & Dissertation & 2 & $\begin{array}{l}\text { The need for longitudinal data on } \\
\text { the effects of strategic planning. }\end{array}$ \\
\hline
\end{tabular}




\begin{tabular}{|c|c|c|c|}
\hline $\begin{array}{l}\text { Author, Title } \\
\text { (alphabetical) }\end{array}$ & $\begin{array}{l}\text { Description } \\
\text { of Work }\end{array}$ & $\begin{array}{l}\text { Value } \\
\text { Rating } \\
\text { 1=Great } \\
\text { 2=Some } \\
\text { 3=Little }\end{array}$ & Focus \\
\hline $\begin{array}{l}\text { Caplow, Theodore. (1983). Managing } \\
\text { An Organization. }\end{array}$ & Book & 2 & $\begin{array}{l}\text { Book is general; short section on } \\
\text { planning. Landmark on } \\
\text { management. }\end{array}$ \\
\hline $\begin{array}{l}\text { Caradonio, James Anthony. (1991). "An } \\
\text { Evaluation of Key Results Planning in } \\
\text { the Cambridge Public Schools } \\
\text { (Massachusetts, Planning Processes)." }\end{array}$ & Dissertation & 2 & Key Results Planning \\
\hline $\begin{array}{l}\text { Chaskin, Robert J. (1996). "Grassroots } \\
\text { Development from the Top Down: } \\
\text { Democratic Principles and } \\
\text { Organizational Dynamics in a } \\
\text { Community Development Initiative." }\end{array}$ & Dissertation & 2 & Rationality Balance of Power. \\
\hline $\begin{array}{l}\text { Cissell, Homer Leo, Jr. (1993, } \\
\text { February). "The Relationship of Locus- } \\
\text { of-Control to Strategic Planning } \\
\text { Behaviors of Administrators of Post } \\
\text { secondary Occupational Programs in } \\
\text { Illinois Community Colleges." }\end{array}$ & Dissertation & 2 & $\begin{array}{l}\text { Individual's personal beliefs } \\
\text { (locus of control) in planning. }\end{array}$ \\
\hline $\begin{array}{l}\text { Cleland, David I. and King, William R. } \\
\text { (1974, June). "Developing a Planning } \\
\text { Culture for More Effective Strategic } \\
\text { Planning." }\end{array}$ & Article & 2 & $\begin{array}{l}\text { Radically new planning processes } \\
\text { can disrupt an organization. }\end{array}$ \\
\hline $\begin{array}{l}\text { Cuthbert, Ronald H. (1996). "The } \\
\text { Strategic Planning Process of } \\
\text { Agricultural Niche Marketers: A Case } \\
\text { Study Approach." }\end{array}$ & Dissertation & 3 & $\begin{array}{l}\text { Marketing of cellular data to } \\
\text { understand current conditions } \\
\text { and anticipate changes that have } \\
\text { strategic implications. }\end{array}$ \\
\hline $\begin{array}{l}\text { Daake, Donald Dean. (1995). "An } \\
\text { Investigation of the Utilization of } \\
\text { Information in Strategic Planning Within } \\
\text { a Loosely Coupled Organization." }\end{array}$ & Dissertation & 2 & $\begin{array}{l}\text { How explicit and tacit } \\
\text { information is used for strategic } \\
\text { decision making when } \\
\text { organization is dominated by } \\
\text { powerful stakeholder groups. }\end{array}$ \\
\hline $\begin{array}{l}\text { Desloriers, Vicki Russell. (1993). “An } \\
\text { Examination of the Strategic Planning } \\
\text { Process at Endicott College: A Case } \\
\text { Study of Decision-Making to Cope with } \\
\text { Change (Massachusetts).” }\end{array}$ & Dissertation & 2 & $\begin{array}{l}\text { Campus forces subverted the } \\
\text { strategic planning process }\end{array}$ \\
\hline
\end{tabular}




\begin{tabular}{|c|c|c|c|}
\hline $\begin{array}{l}\text { Author, Title } \\
\text { (alphabetical) }\end{array}$ & $\begin{array}{l}\text { Description } \\
\text { of Work }\end{array}$ & $\begin{array}{l}\text { Value } \\
\text { Rating } \\
\text { 1=Great } \\
\text { 2=Some } \\
\text { 3=Little }\end{array}$ & Focus \\
\hline $\begin{array}{l}\text { Dievler, Anne. (1996). "The Politics of } \\
\text { Public Health Policy in an Urban } \\
\text { Bureaucracy: HIV Prevention, } \\
\text { Tuberculosis Control, and Immunization } \\
\text { Programs in Washington, D.C." }\end{array}$ & Dissertation & 2 & $\begin{array}{l}\text { Leadership vs. Fragmented } \\
\text { Authority. }\end{array}$ \\
\hline $\begin{array}{l}\text { Donsky, Aaron P. (1994). “IEPM: An } \\
\text { Integrated Planning Effectiveness } \\
\text { Model.” }\end{array}$ & Article & 2 & $\begin{array}{l}\text { Describes an integrated planning } \\
\text { strategy. Refutes Wildavski. }\end{array}$ \\
\hline $\begin{array}{l}\text { Drucker, Peter F. (1974). Management: } \\
\text { Tasks, Responsibilities, Practices. }\end{array}$ & Book & 1 & $\begin{array}{l}\text { Landmark work on all aspects of } \\
\text { management }\end{array}$ \\
\hline $\begin{array}{l}\text { Falsey, Thomas A. (1989). Corporate } \\
\text { Philosophies \& Mission Statements: a } \\
\text { Survey Guide for Corporate } \\
\text { Communications \& Management. }\end{array}$ & Book & 2 & $\begin{array}{l}\text { Deals with the foundational } \\
\text { activities of planning. }\end{array}$ \\
\hline $\begin{array}{l}\text { Garansuay, Ruben. (1997). } \\
\text { "Comparison of Total Quality } \\
\text { Management Practices in Selected } \\
\text { Organizations (Leadership)." }\end{array}$ & Dissertation & 1 & $\begin{array}{l}\text { Important because of } \\
\text { comparisons. }\end{array}$ \\
\hline $\begin{array}{l}\text { Geddes, Lindsay, ed. (1991). Strategic } \\
\text { Planning for Action and Results. }\end{array}$ & Book & 2 & $\begin{array}{l}\text { Collection of articles and essays } \\
\text { on strategic planning. }\end{array}$ \\
\hline $\begin{array}{l}\text { Gee, Jacqueline Arleah. (1994). } \\
\text { "Planning for Education in Alberta: A } \\
\text { Case Study (Strategic Planning)." }\end{array}$ & Dissertation & 2 & $\begin{array}{l}\text { Compares planning } \\
\text { methodologies and the } \\
\text { involvement of stakeholders. }\end{array}$ \\
\hline $\begin{array}{l}\text { Goldberg, Beverly; Sifonis, John G. } \\
\text { (1994). Dynamic Planning: The Art of } \\
\text { Managing Beyond Tomorrow. }\end{array}$ & Book & 1 & $\begin{array}{l}\text { Presents planning as a dynamic } \\
\text { enterprise in dynamic } \\
\text { organizations. }\end{array}$ \\
\hline $\begin{array}{l}\text { Grab, Friedrich Otto Rudi. (1993). "The } \\
\text { Status of the Strategic-Planning Process } \\
\text { and Its Impact on the Quality of Planning } \\
\text { Practices Used in Alberta School } \\
\text { Systems (Strategic Planning)." }\end{array}$ & Dissertation & 2 & $\begin{array}{l}\text { Attitudes of administrators and } \\
\text { their effect on planning practices. }\end{array}$ \\
\hline $\begin{array}{l}\text { Graham, John W. and Havlick, Wendy C. } \\
\text { (1994). Mission Statements: A Guide to } \\
\text { the Corporate \& Nonprofit Sectors. }\end{array}$ & Book & 2 & $\begin{array}{l}\text { How sense of mission affects } \\
\text { planning and implementation. }\end{array}$ \\
\hline
\end{tabular}




\begin{tabular}{|c|c|c|c|}
\hline $\begin{array}{l}\text { Author, Title } \\
\text { (alphabetical) }\end{array}$ & $\begin{array}{l}\text { Description } \\
\text { of Work }\end{array}$ & $\begin{array}{l}\text { Value } \\
\text { Rating } \\
\text { 1=Great } \\
\text { 2=Some } \\
\text { 3=Little }\end{array}$ & Focus \\
\hline $\begin{array}{l}\text { Granger, Christine L. (1996). "Strategic } \\
\text { Economic Development Planning in a } \\
\text { Rural Community: Problems and } \\
\text { Possibilities for Collaborative Planning } \\
\text { Within Fresno County, CA." }\end{array}$ & Dissertation & 2 & $\begin{array}{l}\text { SWOT (strengths, weaknesses, } \\
\text { opportunities, and threats) and } \\
\text { competitive analyses. }\end{array}$ \\
\hline $\begin{array}{l}\text { Harvey, Bryan Curtis. (1997). "Starting } \\
\text { Right: Diagnosing Institutional } \\
\text { Readiness to Engage in Successful } \\
\text { Strategic Planning." }\end{array}$ & Dissertation & 1 & $\begin{array}{l}\text { History of planning in higher } \\
\text { education. Deals with "rational" } \\
\text { and "strategic" approaches. Five } \\
\text { conditions for planning. }\end{array}$ \\
\hline $\begin{array}{l}\text { Higgins, J.C. (1980). Strategic Planning } \\
\text { Systems: Principles and Practice. }\end{array}$ & Book & 2 & $\begin{array}{l}\text { Administrative attitudes toward } \\
\text { planning. }\end{array}$ \\
\hline $\begin{array}{l}\text { Hoy, Wayne K. and Miskel, Cecil G. } \\
\text { (1987). Educational Administration: } \\
\text { Theory Research and Practice. }\end{array}$ & Book & 2 & $\begin{array}{l}\text { General information on school } \\
\text { admin. including planning. }\end{array}$ \\
\hline $\begin{array}{l}\text { Hrebiniak, Lawrence G. and Joyce, } \\
\text { William F. (1981). Implementing } \\
\text { Strategy. }\end{array}$ & Book & 1 & $\begin{array}{l}\text { Discusses rationality in } \\
\text { organizations. }\end{array}$ \\
\hline $\begin{array}{l}\text { Kallman, Ernest A., Reinharth, Leon, } \\
\text { Shapiro, Jack H. (1981). The Practice of } \\
\text { Planning: Strategic, Administrative and } \\
\text { Operational. }\end{array}$ & Book & 1 & $\begin{array}{l}\text { Planning as a continuing } \\
\text { function. }\end{array}$ \\
\hline $\begin{array}{l}\text { Kemm, Elizabeth. (1997). "The Effects } \\
\text { of Using Information Technology to } \\
\text { Support Evaluation of Feedback and } \\
\text { Implementation of Adjustments in an } \\
\text { Organization's strategic Planning } \\
\text { Process." }\end{array}$ & Dissertation & 2 & High-tech feedback loop. \\
\hline $\begin{array}{l}\text { Lawson, Philip Andrew. (1996). } \\
\text { "Managing Strategic Change: The ABCs } \\
\text { of the "Whys" and "Hows" (Planning)." }\end{array}$ & Dissertation & 1 & $\begin{array}{l}\text { Planning models and strategy } \\
\text { formulation. }\end{array}$ \\
\hline $\begin{array}{l}\text { Lorange, Peter. Implementation of } \\
\text { Strategic Planning. }\end{array}$ & Book & 2 & $\begin{array}{l}\text { Contains a model for a } \\
\text { consultant's intervention process. }\end{array}$ \\
\hline $\begin{array}{l}\text { Lovinguth, Sandra J. (1996). "Strategic } \\
\text { Planning Outcomes at Four-year Private } \\
\text { Colleges and Universities." }\end{array}$ & Dissertation & 2 & Organizational effectiveness. \\
\hline
\end{tabular}




\begin{tabular}{|c|c|c|c|}
\hline $\begin{array}{c}\text { Author, Title } \\
\text { (alphabetical) }\end{array}$ & $\begin{array}{l}\text { Description } \\
\text { of Work }\end{array}$ & $\begin{array}{l}\text { Value } \\
\text { Rating } \\
\text { 1=Great } \\
\text { 2=Some } \\
\text { 3=Little }\end{array}$ & Focus \\
\hline $\begin{array}{l}\text { McDaniel, Dayna M. (1997). "Effective } \\
\text { Total Quality Management } \\
\text { Implementation by Capital City } \\
\text { Governments (Local Government)." }\end{array}$ & Dissertation & 1 & $\begin{array}{l}\text { TQM as a management process } \\
\text { recognized by federal, state and } \\
\text { local governments. }\end{array}$ \\
\hline $\begin{array}{l}\text { Modica, Cheryl A. (1997). "Models of } \\
\text { Effectiveness as Decision-making Tools: } \\
\text { A Study of Primary Care Association } \\
\text { Networks." }\end{array}$ & Dissertation & 1 & Feedback loops. \\
\hline $\begin{array}{l}\text { Moore, J. I. (1992) Writers on Strategic } \\
\text { Management. }\end{array}$ & Book & 1 & $\begin{array}{l}\text { Landmark book describing the } \\
\text { work of significant authors. }\end{array}$ \\
\hline $\begin{array}{l}\text { Nerone, Frederick A. (1997). "Applying } \\
\text { the Strategic Planning Process to Small } \\
\text { Business Enterprises." }\end{array}$ & Dissertation & 2 & $\begin{array}{l}\text { SWOT model of strategic } \\
\text { planning. }\end{array}$ \\
\hline $\begin{array}{l}\text { Nessmith, Paula F. (1992). "An } \\
\text { Analysis of the Strategic Planning } \\
\text { Process as Applied to the School Board } \\
\text { of Palm Beach County (Florida)." }\end{array}$ & Dissertation & 2 & $\begin{array}{l}\text { Strategic planning is easier to } \\
\text { apply in the private sector. } \\
\text { Stakeholder participation. } \\
\text { Action team phase. }\end{array}$ \\
\hline $\begin{array}{l}\text { O'Connor, Rochelle. (1983) "Tracking } \\
\text { the Strategic Plan: A Research Report } \\
\text { from the Conference Board." }\end{array}$ & Report & 1 & $\begin{array}{l}\text { Important discussion of } \\
\text { implementation }\end{array}$ \\
\hline $\begin{array}{l}\text { Ozembloski, Lloyd William. (1994). } \\
\text { "The Process of Educational Change: A } \\
\text { School-Based Management Initiative in } \\
\text { Two Western Canadian Public School } \\
\text { Districts." }\end{array}$ & Dissertation & 1 & $\begin{array}{l}\text { Fullam's three phases of the } \\
\text { change process: initiation, } \\
\text { implementation, and } \\
\text { continuation. }\end{array}$ \\
\hline $\begin{array}{l}\text { Roberts, Carolyn S. (1997). "Leading } \\
\text { Change to Create the Future: A } \\
\text { Comparative Case Study of NASA and } \\
\text { Xerox." }\end{array}$ & Dissertation & 2 & $\begin{array}{l}\text { Comparing two globally } \\
\text { respected organizations about } \\
\text { leading change to create the } \\
\text { future. }\end{array}$ \\
\hline $\begin{array}{l}\text { Schrader, David A. (1995). "Toward the } \\
\text { Environmentally Sustainable } \\
\text { Corporation: The Challenges of } \\
\text { Implementing Change." }\end{array}$ & Dissertation & 2 & Leadership top-driven. \\
\hline $\begin{array}{l}\text { Simon, Herbert A. (1997) } \\
\text { Administrative Behavior. }\end{array}$ & Book & 1 & $\begin{array}{l}\text { Key statements on goals, } \\
\text { communication, the review } \\
\text { process. }\end{array}$ \\
\hline $\begin{array}{l}\text { Sloma, Richard S. (1984) No-Nonsense } \\
\text { Planning. }\end{array}$ & Book & 2 & $\begin{array}{l}\text { Simple presentation of the } \\
\text { elements of strategic planning. }\end{array}$ \\
\hline
\end{tabular}




\begin{tabular}{||l|l|l|l||}
\hline \multicolumn{1}{|c|}{$\begin{array}{c}\text { Author, Title } \\
\text { (alphabetical) }\end{array}$} & $\begin{array}{l}\text { Vescription } \\
\text { of Work } \\
\text { Rating } \\
\text { 1=Great } \\
\text { 2=Some } \\
3=\text { Little }\end{array}$ & \multicolumn{1}{|c||}{ Focus } \\
\hline $\begin{array}{l}\text { Steiner, George A. (1979). Strategic } \\
\text { Planning: What Every Manager Must } \\
\text { Know. }\end{array}$ & Book & 1 & $\begin{array}{l}\text { The futurity of current decisions. } \\
\text { Intuitive-anticipatory vs. formal- } \\
\text { strategic planning. }\end{array}$ \\
\hline $\begin{array}{l}\text { Talbot, Sue H. (1992). "Strategic } \\
\text { Planning: A Case Study (Lead Project, } \\
\text { Indiana, School Reform)." }\end{array}$ & Dissertation & 1 & $\begin{array}{l}\text { Implementation of strategic plan. } \\
\text { Annual review. } \\
\text { Community stakeholders. }\end{array}$ \\
\hline $\begin{array}{l}\text { Vincent, Troy Jude. (1993, May). } \\
\text { School District Improvement Through } \\
\text { Strategic Planning; A Case Study (Des } \\
\text { Moines Public Schools, Iowa)." }\end{array}$ & Dissertation & 1 & $\begin{array}{l}\text { Robert Terry's Human Action } \\
\text { Model. } \\
\text { Structure to keep loudest voices } \\
\text { from controlling process. }\end{array}$ \\
\hline $\begin{array}{l}\text { Williams, Dennis Richard. (1992). } \\
\text { "Perspectives on Strategic Planning in } \\
\text { Durham County Schools (Planning } \\
\text { Process, North Carolina)." }\end{array}$ & Dissertation & 2 & $\begin{array}{l}\text { Discusses "futures" approach to } \\
\text { planning. }\end{array}$ \\
\hline $\begin{array}{l}\text { Wishnia, Gracie S. (1996). "Adult Day } \\
\text { Cares and Public Policy: A Strategic Plan } \\
\text { for the Louisville Metropolitan Area } \\
\text { (KY)." }\end{array}$ & Dissertation & 2 & SWOT. \\
\hline \hline
\end{tabular}

\section{Mission}

The concept of mission in an organization relates to the most basic purpose for which that organization exists. The mission statement should capture the organization's "raison d'être", if you will.

Drucker (1974) defines the purpose of mission identification and articulation in a business enterprise as answering the questions, "what is our business and what should it be":

Only a clear definition of the mission and purpose of the business makes possible clear and realistic business objectives. It is the foundation for priorities, strategies, plans, and work assignments. It is the starting point for the design of managerial jobs and above all, for the design of managerial structures. Structure follows strategy. Strategy determines what the key 
activities are in a given business. And strategy requires knowing

"what our business is and what it should be." (p. 75)

Steiner (1979) comments on Drucker's statement:

It must not only identify lives of business and markets served but also determine how the business will operate. This task requires nothing short of thinking through and spelling out as Drucker has said, the 'theory of the business.'

This might sound a bit abstract but it is one of the most pragmatic tasks a top executive can perform. It is only upon the foundation of the basic purposes and missions of the company that more detailed objectives, strategies, and tactical plans can be worked out. (p. 149)

In the foreword to their book, which is an encyclopedic listing of corporate mission and philosophy statements, Graham and Havlick (1974) give a comprehensive view of the purpose of mission statements:

...In short, the mission describes the organization's product, service, market, and technology in a way that reflects the values and priorities of the strategic decision makers.

An organization's systematically and comprehensively developed mission statement can serve as an invaluable tool in directing the formulation and implementation of strategy. An organization achieves a heightened sense of purpose when its managers address the issues of: "Why does this organization exist?" "What needs do we fulfill?" "What customers do we serve?" Through its mission statement, or vision statement as it is sometimes known, managers and leaders attempt to clearly articulate its long-term intentions so that its goals can serve as a basis for shared expectations, planning, and performance evaluation.

The critical role of the organization mission as the basis of orchestrating managerial action is repeatedly demonstrated by failing organizations whose short-run actions are ultimately found to be counterproductive to their long-run purpose.

The principal value of a mission statement as a tool of strategic managers is derived from its specification to the ultimate aims of the organization. It thus provides managers with a unity of direction that transcends individual, parochial and transitory 
needs. It promotes a sense of shared expectations among all levels and generations of employees. It consolidates values over time and across individuals and interest groups. It projects a sense of worth and intent that can be identified and assimilated by organization outsiders, i.e., customers, clients, suppliers, competitors, local committees, and the general public. Finally, it affirms the organization's commitment to responsible action, which is symbiotic with its needs to preserve and protect the essential claims of insiders for sustained survival, growth, and financial viability of the organization.

In the non-profit sector, an organization's mission is even more significant to it's operation because rather than influencing the"bottom line", it $\underline{\text { is }}$ the bottom line. Non-profit entities, whether government, medical, social service, religious, educational, or whatever, exist to fulfill their mission without regard to profit or loss except to the extent that they have adequate resources to continue operating.

There are, however, significant similarities in planning and management that make the basic concepts transferable. Stephen Stark (1997) does a comparative study of organizations who use Total Quality Management (TQM). His subjects are school administrators, military reserve officers and private industry managers. McDaniel (1997) studied TQM implementation in capital city governments. Obviously, the basic tenets of TQM are thought to be transferable concepts which are being applied and studied in both industry and the nonprofit sector.

Strategic planning has also been studied in a variety of settings including profitmaking organizations such as colleges (Lovinguth, 1996), schools (Baldwin, 1994; Stone, 1993), churches (Burgess, 1997), and even small farms (Cuthbert, 1996). 
Newland (1997) engages in a comparative study of planning in two huge but very different organizations - NASA (National Aeronautics and Space Administration) and Xerox Corporation.

It is essential that these comparative studies proceed because from them come principles which can provide the framework for effective planning in almost any setting, including the subject of this study, schools accredited by ACSI.

Development and acceptance of an organization's mission statement is more than a process of "sloganeering." It is central to not only planning but implementation in that, until the different stakeholder groups agree on the organization's mission, the process of planning and implementation can be hindered. Aspects of this theme are discussed in the literature.

Brumfield (1996) refers to Holt's three stages of decision-making: platform, deliberations, and policy. She includes mission development in the platform stage which is the organizational base from which the other stages proceed.

Bastin (1996) examines the deterioration of consensus-based agreements among stakeholder groups in long-range planning. His conclusion is that where the group's mission was conceptualized, articulated, and generally accepted by the members there was very little deterioration of consensus over time. Bastin suggests that one reason for consensus retention is that the "mission" aspect of planning is not operationally specific. The data he presents seem to suggest that the more detailed aspects of plan implementation deteriorate faster. This would seem to strengthen the idea that mission is foundational to a successful plan and relatively long lived. Implementing strategies and procedures may be more short term and subject to more frequent change. 
Herbert A. Simon (1997) presents a foundational view of what a mission statement should be and how significant it is to the decision-making process in any organization.

We hear a good deal these days about an organization's need for a "vision statement" and "mission statement." Many of the manifestos produced in response to this supposed need appear to contain little more than apple pie and motherhood. A proclamation that a company is going to make high quality products, give its customers what they want and need, treat its employees fairly and generously, and provide the greatest possible returns to its stockholders is not likely to have any noticeable effect upon decision-making or other corporate behavior. The sentiments expressed are laudable, but they don't even hint at what to do.

But cynicism about the effectiveness of platitudes should not cause us to dismiss as unimportant the sharing, by both executives and non-managerial employees, of a common conception of an organization's goals: of the particular strengths and comparative advantages it can best employ to establish and maintain a competitive niche, and the "style" and strategies best designed to exploit and enhance these strengths and advantages. In previous chapters I have used the term "representation" to speak of the ways in which an organization characterizes itself. Finding an appropriate representation is especially important to the achievement of effective cooperation in new and growing organizations, and making sure that such a representation is conceived and then promulgated until it permeates the decision processes of the organization is an important leadership responsibility. (pp. 332-333)

For the reasons Simon cites, the schools in this study were surveyed as to whether or not they had a mission statement. Interestingly, $100 \%$ of all respondents, including those who reported having no long-range plan for carrying out the mission, reported having a mission statement! 
So we see that whether studies examine major corporations, small organizations with a "mission" in the religious sense, or educational entities whose missions are varied, the mission of an organization is what informs its goals and objectives.

\section{Key Result Areas}

In their book Implementing Strategy, Hrebiniak and Joyce (1984) refer to the "determination of key result areas to guide the setting of objectives." They explain this as focusing an organization's resources into selected, and therefore limited, areas:

Faced with opportunities on many fronts, managers select a restricted set of areas within which to concentrate their resources and efforts, the assumption being that the major portion of the variance in organizational performance can be accounted for by a relatively small subset of strategic actions. (p. 31)

The idea here is that once the mission of the organization is clearly established, attention is turned toward the process of getting focused on the activities and areas of activity that will most effectively move the organization in the directions best suited to the accomplishments of that mission.

There are no absolutes in either the choosing of key result areas or the achievement of mission. Judgements made about the future are made based on available data and filtered through individual and organizational values. This is why Steiner (1979) discusses the "futurity" of current decisions and Kallman, Reinharth and Shapiro (1981) speak of planning as a "continuing function." What these researchers are saying is that while it is impossible to predict, let alone control the future in a dynamic organizational environment, getting and staying focused on the areas that matter is foundational to being effective. 
Even though the environment may change and shift and the future may reveal the need for adjustments, the function of planning needs to be focused on the areas which are key to producing the desired results. The activity of narrowing organizational focus into key result areas is intended to prevent a great deal of unnecessary experimentation and wasted effort in the development of objectives and goals.

The process may be compared to a funnel in which the broad resources and possibilities of the organization, both fiscal and human, are brought to bear on those actions which are relevant to the organization's mission. Necessarily, the converse is true. In creating this channel for the organization's resources, its leaders are also steering away from those activities which are not relevant to its mission. Not enough can be said about the importance of this stage of planning. It truly sets up the structure for the setting of goals and objectives which are realistic and related dynamically to the mission of the organization.

Not everyone uses the term "key result areas" when describing the process of focusing an organization's resources. As with any other concept, there are myriad terms used to communicate the idea. It may be expressed as simply as "setting priorities". Nevertheless, it is necessary to focus the energy and resources of the organization toward its aims in a purposeful way.

In strategic planning the development of key result areas is related to surveying the organization's “stakeholder" groups. These are the people or groups of people who have a significant interest or "stake" in the success of the organization. Various methods are used to get information from stakeholders which can be used to focus the organization's resources and efforts. 
Much has been written about the behavior, influence and interactions of "stakeholder groups." Daake (1995) and Desloriers (1993) discuss the power of stakeholder participation to either support or undermine the planning process. Baldwin (1994) writes about the significance of stakeholder involvement. There is general agreement that the mission of the organization is the rallying point, pro or con, for stakeholder consensus.

Modica (1997) presents a method called "multiple effectiveness assessments." She writes:

By using this approach, organizations can achieve a balance between maintaining the organizational system and creating variation so as to be capable of adapting to future environments." (p. 1)

The method is to solicit information from stakeholders to identify "constraints, opportunities, and expectations, respectively, which impact organizational performance" (p.2).

Another method which appears in the literature is SWOT, also known as the Harvard Model of Strategic Planning (Wishnia, 1996). This method creates organizational focus by identifying strengths, weaknesses, opportunities and threats, hence the acronym SWOT. It is typically used early in the planning process with stakeholders in an effort to identify key result areas or organizational priorities (Granger, 1996; Nerome, 1997; Wishnia, 1996).

However it is described or carried out, the process of identifying key result areas truly sets the stage for the next step in rational planning which is to establish goals and objectives. 


\section{Goals and Objectives}

Within these key result areas which are based on the organization's mission, goals and objectives are formed. The words goal and objective have almost identical dictionary definitions. They are both described as an "end toward which effort is directed" (Webster's Seventh New Collegiate Dictionary).

In the literature, often the terms are used interchangeably, especially when used in the most general sense. Simon (1997) states:

Most organizations are oriented around some goal or objective which provides the purpose toward which the organization's decisions and activities are directed. (p. 142)

When the two words are described in linear terms, objectives are often described as

ultimate ends while goals are presented as intermediate steps. Again Simon (1997):

The definition of objectives for public service is far from a simple task. In the first place, it is desirable to state the objectives so far as possible in terms of values. That is, only if they are expressions of relatively final ends are they suitable value-indices. When objectives are stated in terms of intermediate goals, there is a serious danger that decisions governed by the intermediate end will continue to persist even when that end is no longer appropriate to the realization of value. (p. 253)

When objectives and goals are presented in a more quantitative description, objectives are often presented as larger and goals as smaller parts of the planning puzzle. Kallman, Reinharth, and Shapiro (1981) present the terms in this way:

An objective is a highly desirable ambition toward which a firm works; it is usually unattainable within a planning period. A goal, however, is a milestone along the path toward an objective; its attainment is planned within the planning period. (p. 31) 
To supplement the previous discussion, the concept of objectives and goals can best be illustrated by use of examples:

- The National Aeronautics and Space Administration's objective is to reach the stars. One of its goals is to have reusable space vehicles circling the earth in the 1980's.

- The objective of every football team is to win the Super Bowl. Its intermediate goal, for example, might be to acquire a proven head coach or a new first-string quarterback.

- The United States' objective is not to be dependent on foreign oil in the future. One of its goals is to achieve more efficient use of that oil by requiring automobile manufacturers to increase substantially the average miles per gallon performance of the vehicles they produce.

If a company is to logically determine and develop its goals, it must first decide what its corporate objective is. (p. 33)

Sometimes the discussion of goals and objectives is more qualitative. That is, rather than compare the relative size of the concepts or the order in which they flow, the qualities or characteristics of the concepts are described. Drucker (1974) discusses goals and objectives from this perspective. He gives a list of five qualities of objectives, and goals appear in item five by way of contrast.

1. Objectives must be derived from "what our business is, what it will be, and what it should be." They are not abstractions. They are the action commitments through which the mission of a business is to be carried out, and the standards against which performance is to be measured. Objectives, in other words, are the fundamental strategy of a business.

2. Objectives must be operational. They must be capable of being converted into specific targets and specific assignments. They must be capable of becoming the basis, as well as the motivation, for work and achievement.

3. Objectives must make possible concentration of resources and efforts. They must winnow out the fundamentals among the goals of a business so that the key resources of men, money, and physical facilities can be concentrated. They must, therefore, be selective rather than encompass everything.

4. There must be multiple objectives rather that a single objective. 
Much of today's lively discussion of management by objectives is concerned with the search for the "one right objective." This search is not only likely to be as unproductive as the quest for the philosopher's stone; it does harm and misdirects.

To manage a business is to balance a variety of needs and goals. And this requires multiple objectives.

5. Objectives are needed in all areas on which the survival of the business depends. The specific targets, the goals in any objective area, depend on the strategy of the individual business. But the areas in which objectives are needed are the same for all businesses, for all businesses depend on the same factors for their survival. (pp. 99 - 100)

Goals and objectives are often categorized in other ways. They may be stated as operational or philosophical, for instance. Operational goals would describe concrete actions and aims and philosophical goals would describe the underlying purposes for those actions or aims.

Nevertheless, goals and objectives are the most common terms to describe the constructs which refer to organizational activity in the realm of planning and implementation. Higgins (1980) discusses the categorization of the terms "objective" and "goal" and their connection with organizational mission.

...Thus Ansoff describes a business firm as 'a purposive organization whose behavior is directed towards identifiable end purposes or objectives' but goes on to say that 'when made explicit with the firm, objectives become multi-use tools in appraisal of performance, control, coordination, as well as all phases of the decision process.' Clearly, any organization will possess a hierarchy of objectives from the strategic through the various levels of management whether implicit, explicit or highly formalized as in MBO. Strategic objectives, or corporate objectives, are concerned with the organization as a whole and they may be categorized in several ways: qualitative and quantitative; economic and non-economic.

The word 'goal' is used variously by managers and management writers. To Ansoff a goal is 'the particular value on 
the scale which the firm seeks to attain' or, more specifically, for example, 'to optimize the long-term rate of return on the equity employed in the firm.' To some, goals and objectives are synonymous. Others even place goals at the head of a hierarchy, e.g. J.A.F. Stoner states that 'Goals provide the basic sense of directions for the organization's activities. They consist of the purpose, mission, objectives, and strategies of the organization.' The author's own preference is to restrict the word to specific quantitative statements of intention, e.g. our goal is to achieve a $15 \%$ net of tax return on this project. (pp. 2-4)

The goals and objectives of non-profit organizations in general and schools in particular flow from the organization's mission in much the same way that they would in the world of business. In a discussion about service and profit objectives within business Simon (1997) makes a very cohesive statement that can be applied here:

It has been fashionable in the literature of business administration to debate whether "the" purpose of a business organization is service or profit. There really is no problem to debate about. Certain individuals, primarily the customers, contribute to the organization because of the service it provides; others, the entrepreneurs, because of the profits they may derive. When the system of organization behavior itself is examined, it is found that both service and profit aims influence decisions. It is for terminological convenience that the label of "organization objective" is here applied to the service aim. (p. 142)

The application here should be obvious. Regardless of the nature of the organization or the motives of its stakeholders, goals and objectives need to flow from the mission and purpose of the organization, so that the activities and resources of that organization will be focused in the direction of its ultimate aims and purposes. This process is as real in small private schools as it is in large corporations. 


\section{The Rationality of Planning}

Emerging from the organizational mission, goals, and objectives is the plan itself. The plan may be thought of as long-range, short-range, strategic, operational, etc. For the purposes of this research we have examined long-range plans, but there are any number of structural forms which a plan may take.

Following are just a few examples that appear in the research literature. They are presented here simply to illustrate the variety of models for developing a plan. They are not intended to be analyzed and certainly do not represent an exhaustive listing. Brackett (1997) compares and contrasts two models, the Bill Cook and the SCSDE. Caradonio (1991) describes 'key results planning.' Lawson (1996) compares several planning models. Ozembloski (1994) focuses on Fullam's three phases of the change process and Vincent (1993) analyzes Robert Terry's Human Action Model. The bottom line, however, is that regardless of the plan's structure it springs from the mission, objectives and goals of the organization. The plan then, is the collection and articulation of specific organizational objectives and goals.

When the plan has been reasoned out through the processes described above, is intentional, and desired results are achieved, namely that the organization has met significant objectives and goals that will move it closer to carrying out its mission; we can call the plan rational.

Several writers use the term "means-end relationships" to describe the rationality of planning. Simon (1997) has a great deal to say about this. In his chapter "Rationality in Administrative Behavior," Simon says, in essence, that although the possibilities of human 
behavior are limitless, planning because of its means-end processes and relationships is by its nature a rational activity that will have consequences. Those consequences will occur whether or not they are accurately predicted by the decision maker (pp. 72-91).

Singer (1996) has constructed a very thorough examination of the rational nature of planning. He presents rationality theory and its multi-faceted relationship to strategy. Singer also sees rationality and decision making behavior as being clearly connected (p.12) and summarizes his chapter "Strategy as Rationality" as follows:

The conceptual framework of "Strategy as Rationality" sees that developments in a general theory of rationality are, at the same time, contributing to a richer prescriptive theory of strategy, whilst much strategic management research has itself become directly relevant to the general theory of individual or human rationality. Empirical programs focusing on such issues as corporate competition and cooperation, organizational persistence, divisional autonomy and identity, are, at the same time, also tackling some of the more enduring problems of rationality. (p. 28)

In explaining a "C-to-B-to-A" approach to planning, Sloma (1984) alludes to the rationality of planning as well as the means-end nature of the process:

The bridge needed to reach from the desired circumstances back to the present circumstances must be built on a brick-bybrick basis, with the firm mortar of close reasoning in between.

While it is necessary that planning be approached with conquering enthusiasm, it is equally necessary that the planner remain consummately dispassionate. Failure to remain objective leaves a planner with only wished-for results rather than realistic appraisal of an achievable result. (p. 4)

Rationality also refers to the process of limiting one's plan with the knowledge that resources, information and the ability to predict the future are indeed limited. Hrebiniak and Joyce (1981) discuss rationality as bounded or limited and suggest that these limitations do 
not negate the inherent rationality of the planning process. They use the phrase "intended rationality":

A model of strategy implementation must therefore directly address problems of allocation of attention stemming from limited information processing capability. The model that we present shortly includes the need to selectively attend to implementation problems through appropriate planning and organizing action. These actions delimit both the scope and the time frame of decisions to make them more manageable.

But we must be careful not to become so enamored of theories of limited rationality that we propose theories of nonrationality and arationality in their place. In this book, a model of intended rationality is adopted as an organizing principle for implementation activities. Specifically, the principle of intended rationality proposes that individuals (sic) are limited in their ability to develop alternatives and their consequences, and to make unequivocal choices based upon such analyses and preferences. Typically, they employ logical and individually rational processes for decision within these constraints. Faced with complexity, individuals act to factor large problems into incrementally and cognitively manageable proportions. Given the realities of resource allocation decisions and organizational control systems, managers will seek to achieve utilitarian outcomes to the extent that these are valued and reinforced.

While an implementation model must recognize the limited rationality of decision makers, it must not ignore the predominantly utilitarian nature of organizations and the consequent need to reconcile individual and organizational rationality. (pp. 6-7 emphasis original)

Reference is made in this quote to "nonrationality" or "arationality" and other writers seem to express an apologetic for their theories that takes non-rational perspectives into account. For instance, Simon (1997) in a note refers to the shortcomings of "anarchism:" in that it assumes "that, given common goals, participants in a social scheme will automatically select for themselves their own most effective roles" (p. 82). 
There does not appear to be a strong thread of non-rational theory in the literature pertinent to this study. The article by Wildavsky (1973) is more of a criticism of government planning than a lucid argument of non-rational theory. Gilbert (1992) appears to dismantle the idea of rational strategy only to redefine it as a more complex set of constructs.

It is natural for theorists, particularly in a post-modern, intellectual climate to explore alternative approaches to long-held ideas. However, because planning is a heavily tested pragmatic enterprise which is being carried out with measurable results in thousands of organizations, theories which favor abstract or esoteric ideas are probably held in check to some degree.

In other words, planning theory is more like architecture than art in that form can never really stray very far from function without ominous consequences.

It should be noted in summary that in the non-commercial arena as in government or education theories are not tested in the same way as in industry. Attempting to deliver a product to market has consequences that may provide clearer, more immediate feedback than shifting one's emphasis in math instruction or annexing neighborhoods into a city tax and service base. The potential delay in feedback created by the natural cycles of product or service delivery in the non-profit sector can make consequences, though delayed, even more significant. 


\section{Implementation and Administrative Assessment}

Part of the rationality of planning is the expectation that the plan will be implemented.

This is obvious in the literature. Drucker (1974) simply refers to this as "From Objectives to Doing":

One final step remains: to convert objectives into doing. Action rather than knowledge is the purpose of asking, "What is our business, what will it be, what should it be?" And of thinking through objectives. The aim is to focus the energies and resources of the organization on the right results. The end product of business analysis, therefore, is a work program and specific and concrete work assignments with defined goals, with deadlines, and with clear accountability. Unless objectives are converted into action, they are not objectives, they are dreams. (p. 119)

Many researchers have focused on the implications of implementation. Busler (1992) calls for more longitudinal data on the effects of planning. Haskin (1992) attempts to measure the impact of strategic planning on the daily operation of schools. His project involved a descriptive analysis by use of a questionnaire to employees and parents within the school district. The questionnaire was sent out three years after implementation of the strategic planning process in an effort to determine if the process had an impact on the daily operation of schools within the district. Respondents reported that the process had favorably impacted the operation of eight local schools in four general aspects of school operation.

In Ozembloski's (1984) description of Fullam's three phases of the change process, implementation is phase II and continuation is phase III. In the continuation phase, feedback on performance is a vital component in sustaining the desired changes. 
In systems theory, an essential aspect of any system of change is the feedback loop. Feedback loops not only influence outputs but they also have the effect of modifying the system itself, hopefully making it more effective. In her research on multiple effectiveness assessments, Modica (1997) examines the effect of feedback on "organizational decisionmaking and strategic action selection." She argues that this approach, which involves seeking feedback from three perspectives: Goal, Systems, and Multi-Stakeholder, will help organizations "achieve a balance between maintaining the organizational system and creating variation" in order to better survive in changing environments.

Kemm (1997) explores the use of computer software to increase the speed with which feedback can be made available to decision-makers in a segment of a state Probation and Parole Board. The increased availability of timely feedback was perceived as positive by the respondents.

Sloma (1984) describes implementation as the "actual-to-plan measurement system."

After describing this system in detail, he concludes by saying:

In summary, the more compatible the quantified expression of the objective is with the feedback performance measurement system, the more effective will be monitoring and control, and the more likely it is that your plan will be successfully executed. (p. 36)

Hrebiniak and Joyce (1984) suggest that the design and style of implementation will vary based on various organizational factors. In this project the feedback mechanisms that will be analyzed are the administrator's job description and evaluation document. These two elements play an essential role in evaluating the administrator. The job description sets up the structure or framework as to what aims will be the major and minor focus of the 
administrator's efforts. The evaluation document is intended to produce the feedback necessary to track the administrator's progress relative to implementing the plan.

There are other ways to assess implementation. However, this study approached the problem from the perspective that if it is important to organization control boards that implementation occur, it will be obvious in their documents detailing desired administrative performance and assessment thereof.

Kallman, Reinharth and Shapiro (1981) deal with the issue of how the planning culture of an organization influences implementation and vice-versa. They assert that administrative accountability as well as its rewards and punishments need to be geared toward the future rather than favoring current performance:

...If the system of awards and punishments favors current performance at the expense of the long-run, a powerful, antiplanning culture emerges to deter the executive from giving his attention to the long-range future of the organization.

...Although planning should be participative and nonthreatening, once plans have been approved and accepted by the managers, they should be accountable for them. In this, as in perhaps no other way, can mangers be forced to explicitly consider the shortterm versus long-run trade-offs which are essential to good planning.

Of course, this principle has been accepted by many who have found it difficult to implement. The only effective way of doing so - within the context of an organizational environment in which personnel are constantly changing responsibilities - is to have the plans follow the individual, i.e., to trace the individual's planning performance back to previous jobs. (pp. 26-27)

The concept of administrative assessment is central to the idea of implementation which is being explored in this project. If an organization wants to track the implementation 
of its plan, it should focus on the individual, in this case the head administrator, most responsible for the plan's implementation and hold that person accountable.

\section{Administrative Leadership}

The role of the administrator in actually carrying out the organizational plan is a matter of great interest to researchers and writers on management. Drucker (1974) says of managers:

The manager has to be a craftsman. His first duty is indeed to make his institution perform the mission and purpose for the sake of which it exists - whether this be goods and service, learning, or patient care. (p. 18)

Steiner (1979) refers to the CEO (Chief Executive Officer) as the "linchpin in the development and operation of the strategic planning system." He says, "No other person has anywhere near the influence of the CEO in what is done." For the purposes of this study the school administrator compares to the $\mathrm{CEO}$ of a corporation. In his research on implementing change, Schrader (1995) concludes that a "top-driven" change implementation strategy is what creates shared vision and mobilizes the other parts of the organization. Al-Khalaf (1994) analyzes the success and failure of TQM implementation in small U.S. cities and concludes that one of the important factors for success of TQM is strong commitment and support from top-management.

In examining the failure of rational planning approaches in public health programs, Drevler (1996) concluded that the major issue affecting implementation was the fragmentation of authority. In other words, there was a lack of clear leadership. Lovinguth 
(1996) studied planning outcomes in four-year private colleges and universities and maintained that while several factors influenced the level of implementation, the major factor was presidential leadership.

This evidence would seem to indicate that in a variety of organizations and planning modalities, top leadership is one of the major factors in making the implementation of planning successful. Therefore, the focus of this study on the performance of the head administrator and his role in implementation would seem to be a valid approach to analyzing the planning behaviors of ACSI accredited schools.

It should be noted here that the focus on one administrator is a function of the relatively small size of the organizations (ACSI schools) being studied. 


\section{CHAPTER 3}

\section{Research Design}

\section{Introduction and Problem Statement}

This chapter contains a description of the design of this project relative to methods and procedures for determining the population, gathering and analyzing data, and addressing the problem raised in Chapter I.

The problem is to determine if the existence of a long-range plan has a direct influence on the way a school administration actually operates a school. In other words, if there is a long-range plan, is it being implemented? Additional questions to be addressed include:1) Do school boards believe enough in long-range planning to require the administration to develop and implement the plan as evidenced in job descriptions, evaluation documents, or other procedures? 2) If school administrators and boards do not require the implementation of their plan, could this mean that they do not subscribe to the classic or rational model described above?

\section{The Population Studied}

The population selected for this study consisted of private Christian schools, accredited through the Association of Christian Schools International. The total population is 312 schools. Stratified random sampling methodology was used to select schools for the study from the population of 312 ACSI accredited schools. 
ACSI accredited schools are independent entities controlled by local boards. Though some are affiliated with local churches and/or their denominations, they are still autonomous and locally controlled. These schools are typically run by a person whose title is administrator, or headmaster. This person's authority and responsibility would be comparable to a superintendent of a school system, though on a much smaller scale. For the purposes of this study, the position of administrator compares favorably to the CEO of a corporation.

The schools in the study varied in both size and structure. They varied in size from 103 students to 1015 students. The median size was 348 . The figure below shows the geographic distribution of the schools selected for the study. All of the schools fell within the contiguous forty-eight states. No schools were drawn from Hawaii or Alaska. The nine U.S. regions of ACSI are all represented in the study.

\section{Figure 2}

\section{U.S. Regions of ACSI}

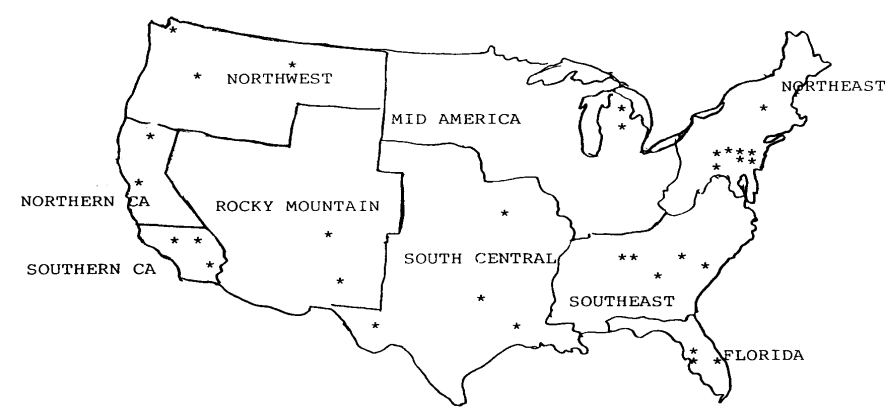


As a requirement for ACSI accreditation, each school must develop a long-range plan. This factor has the effect of stratifying the sample, but since the issue was implementation of the plan, it was appropriate to begin with schools which, in theory at least, had a plan in place.

\section{Principal Methods of Research}

The two broad categories of methods used to conduct this research were surveys and document analysis. The surveys used were as follows: A two-part survey was sent to head administrators to gather demographic data and to explore administrative attitudes toward planning and implementation. The demographic portion contained 10 factual questions. The attitudinal portion of the survey consisted of five questions set up on a Likert scale. A second survey was used to gather data on the attitudes and perspectives of board chairs. It explored their belief in the rational planning model as well as their views on implementation.

The documents analyzed in the study were long-range plans, job descriptions, and performance evaluation documents. They were analyzed and described using a historical descriptive methodology. An effort was made to discover comparative statements that would indicate the intention to hold administrators accountable for the implementation of the longrange plan. 


\section{Data Collection}

Initially, sixty-three schools were chosen at random from a list of 312 ACSI accredited schools in the United States in an effort to glean a sample of thirty-two complete and useable responses. The first mailing, which was followed by a reminder, yielded twenty-one responses from schools with long-range plans. A subsequent sample of forty-eight schools was drawn and received the same mailing. This group yielded eleven useable responses to complete the sample of thirty-two schools needed to proceed with the study. This is a $10.25 \%$ sample of the population and is within small-sample limits according to Ferguson and Takane (1989). (See appendix for samples of letter and questionnaire.)

Overall, a total of fifty schools responded. Nine sent partial or inappropriate responses, nine responded that they had no long-range plan and thirty-two sent complete and appropriate responses. Head administrators from these schools were asked to fill out the questionnaire (appendix A). The questionnaire asked for demographic information such as the existence and age of the plan, the date of the school's most recent accreditation, and how implementation is reviewed. It also contained a survey which explores administrative attitudes toward planning.

Administrators were asked to submit copies of their long-range plans, job descriptions, and evaluation documents (blank). Schools without long-range plans were counted but otherwise eliminated from the study. The percentage of accredited schools with and without plans will be discussed in this chapter along with related demographic information.

A follow-up questionnaire was sent to the board chairs of the thirty-two respondent schools with three questions related to the rational model for planning. Board chairs were 
given a description of this model, mission $\Rightarrow$ goals and objectives $\Rightarrow$ plan (implementation), and asked: 1) if they believed this to be a valid model for planning, 2) if they preferred another model for planning, and 3) if they believed that administrators should be held accountable to implement the school's long-range plan. (See appendix for copy of questionnaire.) Board chairs responded to the questionnaire either by mail or by answering the same questions by telephone.

Schools with plans were categorized as to what kind of implementation is expected. The board's interest in implementation was measured by the presence of elements of the plan in the job description and evaluation documents.

\section{Data Analysis}

The schools were placed in categories as follows:

First, there were three broad categories of respondents.

1. nine partial or inappropriate responses.

2. nine responses of "no plan".

3. thirty-two complete appropriate responses to be considered in the study.

Second, the useable responses were numbered 1-32 and divided into three categories: 
Category A - Schools

Figure 3

\section{Categories of Respondents}

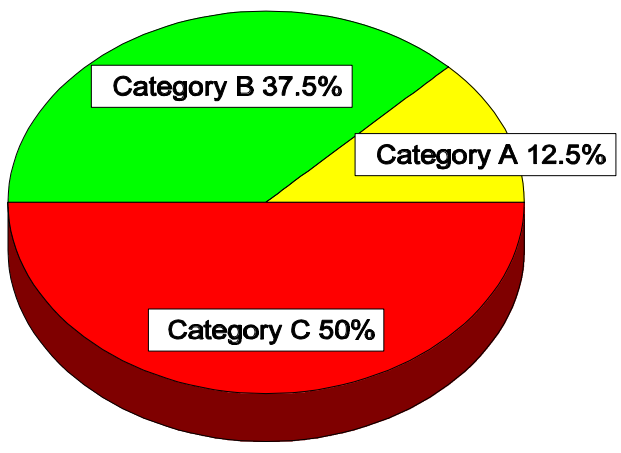

which have a written plan but show no evidence of implementation in the form of parallel statements in administrators' job descriptions or evaluation documents. Four schools (12.5\%) fell into this category.

$$
\text { Category B - Schools }
$$

which have a written plan and

show evidence of implementation based on parallel statements in administrators' job descriptions but not in evaluation documents. Twelve schools (37.5\%) fell into this category.

Category C - Schools which have a written plan and show evidence of implementation in parallel statements in both administrators' job descriptions and evaluation documents. Sixteen schools (50\%) fell into this category. There were no respondents whose documents showed parallel statements in evaluation documents but not in job descriptions. 
A grid was set up to record the comparative statements as in the example below:

\section{Figure 4}

\begin{tabular}{||l|l|l||}
\hline $\begin{array}{l}\text { STATEMENT(S) } \\
\text { FROM LONG- } \\
\text { RANGE PLAN }\end{array}$ & $\begin{array}{c}\text { COMPARATIVE STATEMENT(S) } \\
\text { FROM JOB DESCRIPTION }\end{array}$ & $\begin{array}{c}\text { COMPARATIVE } \\
\text { STATEMENT(S) FROM } \\
\text { EVALUATION } \\
\text { DOCUMENTS }\end{array}$ \\
\hline $\begin{array}{l}\text { SCHOOL \#1 } \\
\text { spiritually mature, } \\
\text { well-rounded, college } \\
\text { prepared students }\end{array}$ & $\begin{array}{l}\text { Of the spiritual mission of the school } \\
\text { Direct the daily operation ... setting the } \\
\text { tone for a quality educational program }\end{array}$ & $\begin{array}{l}\text { No evaluation document } \\
\text { available. }\end{array}$ \\
\hline $\begin{array}{l}\text { Teachers-hiring } \\
\text { talented personnel for } \\
\text { new positions }\end{array}$ & $\begin{array}{l}\text { Manage personnel affairs including } \\
\text { securing staff... }\end{array}$ & \\
\hline
\end{tabular}

Long-range plans, administrators' job descriptions, and performance evaluations were analyzed in an effort to discover whether or not relationships existed between statements in the plan and statements in the other documents. Categorical relationships in which job description and evaluation document statements fell into the same general categories as longrange plan elements were considered.

Direct relationships in which job description or evaluation statements were taken verbatim from the long-range plan were also considered. The reason that job descriptions and performance evaluations were chosen as indicators of implementation is that these two documents play an essential role in evaluating the administrator. The job description lays out aims that will be the major and minor focus of the administrators's efforts. The evaluation document is intended to produce the feedback necessary to track the administrator's progress in implementing the plan. 
There are other ways to assess implementation. However, this study approached the problem from the perspective that if it is important to the control board that implementation occur, it will be obvious in their documents detailing desired administrative performance and assessment thereof. 


\section{CHAPTER 4}

\section{Results}

\section{Demographics}

Of the thirty-two respondents who qualified for the study: Twenty-nine were certified administrators $(90.625 \%)$, one was a certified psychologist, one was a certified teacher and one had no educational certification. Twenty-six administrators $(81.25 \%)$ had advanced degrees. Nineteen of these had master's degrees, five had Ph.D.'s, and two had EdD's in education or related fields. Five $(15.625 \%)$ had bachelors' degrees in education or related fields and one had an SIA (Specialist In Arts)degree.

Years of overall experience as a school

Figure 5

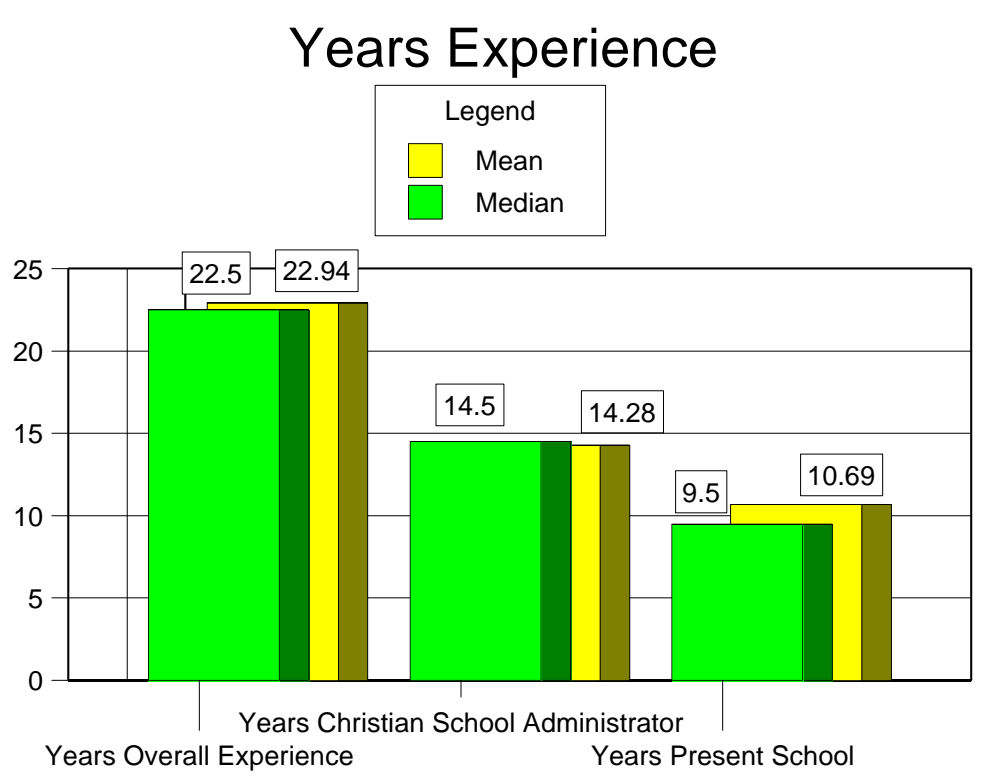

administrator ranged

from 3 to 38 with a median of 22.5 and a mean of 22.9375 .

Years of ex-

perience as a Christian school administrator ranged from 2 to 30 with a median of 14.5 and a mean of 14.28125 . 
Years of experience as administrator at respondent's present school ranged from 1 to 28 with a median of 9.5 and a mean of 10.6875 . The general level of experience in this sample is substantial with overall experience averaging two decades. This means that it is possible that the average administrator has been through as many as four complete five-year planning experiences. It seems as though the average years at present school is also significant at about a decade. This would allow for two complete five-year planning cycles.

It in interesting to note that among the nine schools that registered a "no plan" response and were thus eliminated from the study, eight gave a response that indicated that the present administrator was employed there during the most recent accreditation review. Seven of these schools reported their last accreditation review as being less than five years ago. The other two did not report the date of their last review. This means that since ACSI requires schools applying for accreditation to show the visiting committee a five-year plan, two possibilities exist. One is that the administrator showed the visiting team a five-year plan but no longer considers that plan to be valid. This could be because the plan was near expiration at the time of the visit or there could be other reasons not discernable from this data. The other possibility is that the review team did not actually require the school to produce a five-year plan at the time of the visit.

In contrast, six of the thirty-two schools included in the study (18.75\%) reported accreditation review dates that were more than five years old, indicating that their current long-range plans were most likely to have been created after the five-year plan they showed to the visiting committee had expired. This may suggest that the school views long-range planning as more than a component of accreditation. 


\section{Mission Statements}

All thirty-two respondents who qualified for the study as well as the eighteen who didn't qualify reported that their school has a mission statement. This is interesting in that it is the only category in any aspect of the survey in which there was a $100 \%$ response.

In contemplating what this phenomenon could mean, two possibilities come to mind: The first is the possibility that there is a broad acceptance of a rational model for planning with the classic pattern described above. It contains the following elements:

$$
\text { Mission } \quad \Rightarrow \quad \text { Goals and Objectives } \quad \Rightarrow \quad \text { Plan (Implementation) }
$$

This possibility is credible in that one would expect a rational approach to management in a Christian school. Much of the rationality of Western Culture in general is based on the Judeo-Christian foundation of that culture. In recent years other systems of thought such as eastern mysticism, existentialism, or phenomenology have raised the specter of non-rational philosophy, but one would expect schools whose educational philosophy is rooted and grounded in Christianity to favor a more rational approach.

The second possibility has to do with the fact that Christian schools see themselves as having a broader role in the lives of their students than simply teaching academic disciplines. They often describe themselves as a ministry. Sometimes they are considered a ministry of an individual church. (Several of the schools in this study are church sponsored.)

The late Gene Garrick, pastor of The Tabernacle Church of Norfolk, Virginia, which sponsors Norfolk Christian School writes about this sense of broader ministry to students in a chapter entitled "Developing Educational Objectives for the Christian School": 
These distinctives, held within the evangelical theological framework, dictate certain goals in education for the Christian school. Many of these, of course, coincide with those of the Christian home and the church since all three work from a common base. The school weighs heavily on the academic side because this is in some ways its unique contribution. Not that the home and church do not deal with academics; they must since the mind is necessary to all functions. But it is the avowed purpose of a school to deal with the training of the mind. However, that training is to be related to the total life of the student and thus coordinated with that given at home and in the larger believing community. The school's main task, then, is to produce in the student a Christian mind - an outlook on life viewed through the unique Christian presuppositions and affirmations - a world view that can be termed God-centered - a pattern of thought which interprets life in a truly Christian way. (Keinel, 1978, p. 72)

It is entirely possible that because of this broader role a "sense of mission", or a statement of mission, is a high priority in these schools. It may even be a higher priority than a fully developed long-range plan based on the rational model. The data in this study are somewhat consistent with this idea in that, while all fifty schools reported that they had a mission statement, not all showed evidence of a long-range plan, let alone a system of implementation consistent with this model.

\section{The Survey}

The survey portion of the questionnaire sent to administrators was set up on a Likert scale with the responses SA-strongly agree, A-agree, N-neutral, D-disagree, SD-strongly disagree. There were five questions in the survey. The results are as follows:

1. Schools should develop a written long-range plan.

$$
\text { SA-84.375\% A-15.625\% N-0\% D-0\% } \quad \text { SD-0\% }
$$


2. Long-range plans should reflect the mission of the school.
SA- $87.5 \%$
A-12.5\%
$\mathrm{N}-0 \%$
D-0\%
SD-0\%

3. Implementation of the long-range plan is a major responsibility of the administration.

$$
\text { SA-46.875\% A-40.625\% N-12.5\% } \quad \text { D-0\% } \quad \text { SD-0\% }
$$

4. The administration should be held accountable for the implementation of the long-range plan.

$$
\text { SA-46.875\% A-40.625\% N-9.375\% } \quad \text { D-0\% } \quad \text { SD-3.125\% }
$$

5. The exercise of planning helps to clarify the school's mission, but formal implementation is not really necessary.
SA- $0 \%$
A-3.125\%
$\mathrm{N}-3.125 \%$
D-50\% SD-40.625\%
Blank-3.125\% 
Figure 6

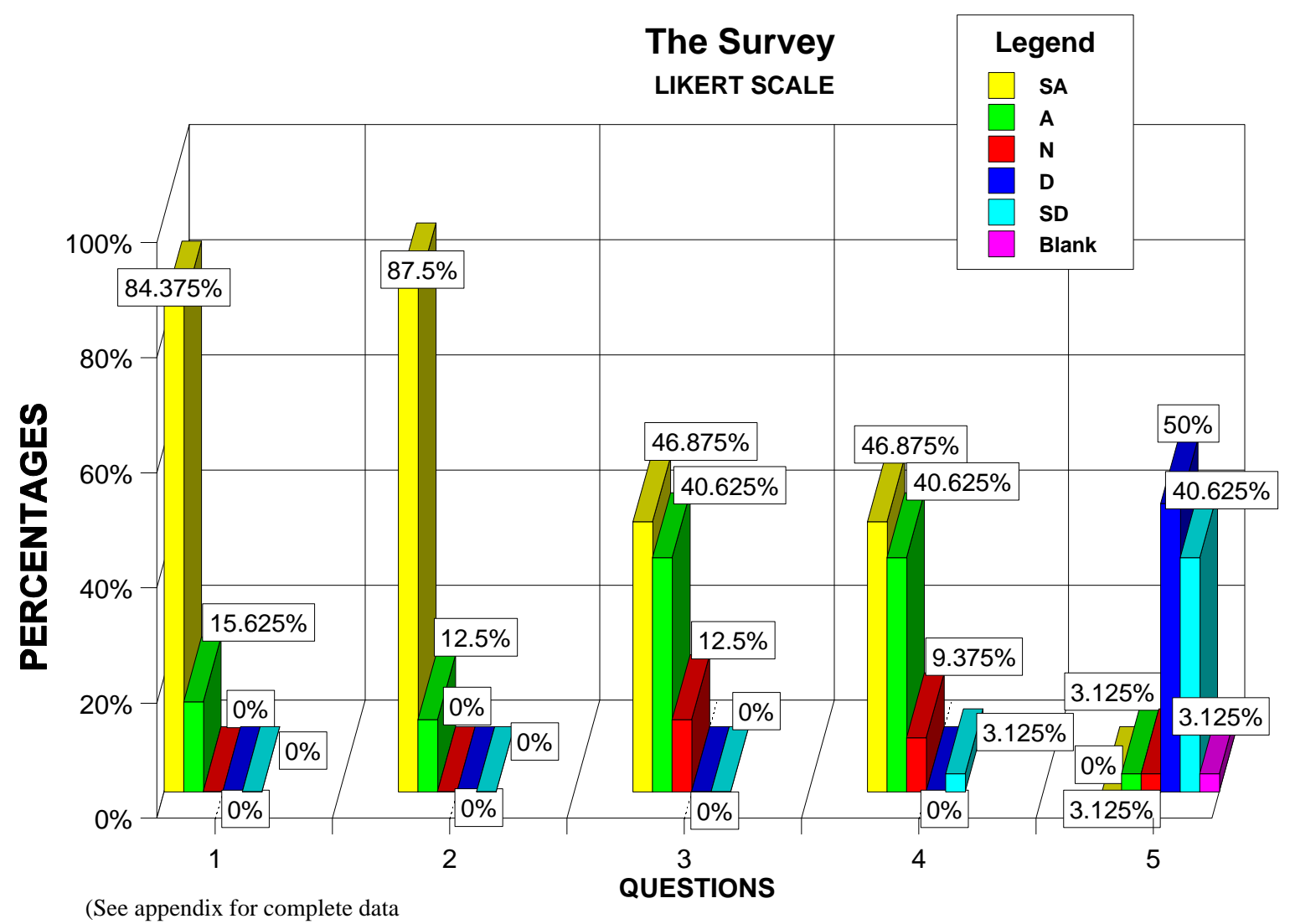

(See appendix for complete data chart.)

It is obvious that within this sample there is strong agreement with statements one through four. This is an indication that the respondents basically believe, in theory at least, in what has been defined as the rational model of planning. That is, a written plan based on the mission of the school which the administration is held accountable to implement. It is especially interesting that identical numbers of respondents $(87.5 \%)$ either agreed or strongly 
agreed on questions three and four, that implementation is a major responsibility for which the administration should be held accountable.

A central issue on this questionnaire was how administrators said that they were held accountable for implementation. The data on these items are shown below:

Elements of the plan in job description: $\quad 37.5 \%$ yes $\quad 62.5 \%$ no

Elements of the plan in evaluation documents: $\quad 12.5 \%$ yes $\quad 87.5 \%$

no

From these two responses the respondents can be placed in categories as described above.

Category A: No elements of the plan in job descriptions or evaluation documents $-62.5 \%$

Category B: Elements of the plan in job description only - $25 \%$

Category C: Elements of the plan in both job description and evaluation documents - 50\%

No administrators reported that elements appear in their evaluation documents only. The perceptions of administrators compare to the actual documents submitted with the questionnaire as follows:

\section{Figure 7}

\begin{tabular}{|c|c|c|}
\hline Category & Administrator's Perception & Evidence in Documents \\
\hline A (neither) & $62.5 \%$ & $12.5 \%$ \\
\hline B (job desc. only) & $25 \%$ & $37.5 \%$ \\
\hline C (both) & $12.5 \%$ & $50 \%$ \\
\hline
\end{tabular}


This comparison reveals that administrators generally underestimated the existence of statements in their job descriptions and evaluation documents that compare to their longrange plans.

Of the sixteen respondents $(50 \%)$ who had no evidence of comparative statements in evaluation documents, twelve had no evaluation documents available. Eight of these reported that their plans are reviewed by the board or a committee thereof. It is possible that these respondents as well as those who show no comparative statements in any of the documentation are indeed being held accountable for their strategic plans. In fact, they could be subject to a more direct form of accountability. However, by the methods of this study it is impossible to tell. This could form the basis for a companion study.

\section{Second Survey}

In the second survey, board chairs from the thirty-two respondent schools were asked if they believed in the rational planning model or if they had an alternative model that they favored. They were also asked if they believed that the administrator should be held accountable for the implementation of the plan.

This second survey was intended to gather data relative to "additional question" number 2 under the Problem Statement section in Chapter 1. The question, worded in the negative, is: "If school boards do not require the implementation of their plan, could this mean that they do not subscribe to the classic or rational model described above?" 
The results of this survey were clear. One hundred percent of the respondents reported that they do subscribe to the classic or rational model. A few suggested that the model is more complex than what was presented in the survey.

On the question of holding the administrator accountable for implementation of the plan, twenty board chairs (91\%) said that the administrator should be held accountable. However, ten respondents (45\%) made comments to the effect that the board is somewhat directly responsible for implementation of the long-range plan. Two respondents (9\%) said that implementation is the board's responsibility ultimately.

\section{Analysis of Documents}

The analysis of the documents began with the summarizing of major points of each of the thirty-two long-range plans. Then comparisons were made to job descriptions and evaluation documents in an effort to establish the existence or non-existence of parallel statements which could be construed as evidence of implementation of the plan.

There are a few important observations to be made regarding the way these documents were analyzed. Long-range plans were condensed into their major components which formed the items listed in the left hand column of the chart. Comparative statements were gleaned from job descriptions and evaluation documents and listed adjacent to the appropriate item in the chart (see Figure 4, p. 46). No consideration was given to the fact that there were multiple statements related to some items. Each set of comparative statements in a category counted as one comparison. Intent here was to discover whether 
there were comparative statements in a category, not to quantify them or otherwise give them weight.

Conversely, if a single statement applied to more than one item it was listed and counted once for each item to which it compared; e.g., case fifteen, items one through three shown in Figure 8 below.

\section{Figure 8}

\begin{tabular}{|c|c|c|}
\hline $\begin{array}{c}\text { STATEMENT(S) } \\
\text { FROM LONG-RANGE PLAN }\end{array}$ & $\begin{array}{c}\text { COMPARATIVE } \\
\text { STATEMENT(S) FROM JOB } \\
\text { DESCRIPTION }\end{array}$ & $\begin{array}{c}\text { COMPARATIVE } \\
\text { STATEMENT(S) FROM } \\
\text { EVALUATION } \\
\text { DOCUMENTS }\end{array}$ \\
\hline $\begin{array}{l}\text { To improve written curriculum } \\
\text { from general departmental } \\
\text { objectives to measurable } \\
\text { objectives in five subject areas } \\
\text { (Bible, English, math, social } \\
\text { studies, science) for each grade } \\
\text { level over the next three years. }\end{array}$ & $\begin{array}{l}\text { Shall submit plans annually for } \\
\text { the development of programs in } \\
\text { curriculum, building, equipment, } \\
\text { and staffing as part of the long } \\
\text { range strategy for the total } \\
\text { development of the school. }\end{array}$ & $\begin{array}{l}\text { - Submits plans annually for the } \\
\text { development of programs in } \\
\text { curriculum, building, equipment, } \\
\text { and staffing as part of the long } \\
\text { range strategy for the total } \\
\text { development of the school. }\end{array}$ \\
\hline $\begin{array}{l}\text { To develop an awareness of safety } \\
\text { issues and to eliminate potential } \\
\text { safety hazards in the areas of the } \\
\text { gym, the shop, the parking lot, } \\
\text { and classrooms. }\end{array}$ & $\begin{array}{l}\text { Shall submit plans annually for } \\
\text { the development of programs in } \\
\text { curriculum, building, equipment, } \\
\text { and staffing as part of the long } \\
\text { range strategy for the total } \\
\text { development of the school. }\end{array}$ & $\begin{array}{l}\text { - Submits plans annually for the } \\
\text { development of programs in } \\
\text { curriculum, building, equipment, } \\
\text { and staffing as part of the long } \\
\text { range strategy for the total } \\
\text { development of the school. }\end{array}$ \\
\hline $\begin{array}{l}\text { To increase family enrollment } \\
\text { through recruitment and retention } \\
\text { by } 2 \% \text { per year for the next three } \\
\text { years. }\end{array}$ & $\begin{array}{l}\text { Oversee the process of } \\
\text { recruitment and retention of } \\
\text { students. }\end{array}$ & $\begin{array}{l}\text { - Oversees the process of } \\
\text { recruitment and retention of } \\
\text { students. }\end{array}$ \\
\hline
\end{tabular}

The underlying purpose here was to establish the existence of evidence which would imply a certain type of implementation. There are complex issues related to the clarity and weight of individual statements and the effectiveness of this concept of implementation which might form a basis for further study. 
Similar treatment was given to statements in job descriptions and evaluation documents in which administrators are directed to develop and implement long-range plans. Each of these sets of statements was counted as one. While these were not the specific objects of this study, it is interesting to note that half of the respondent schools had such statements in administrator's job descriptions and six (18.75\%) had such statements in evaluation documents. This indicates that boards in these respondent schools are concerned not only with the elements of the long-range plan, but are directing administrators to attend to the planning process.

When total percentages were figured, the number of items in the strategic plan was doubled because of the combined opportunities for comparative statements in the job description and evaluation documents. In other words, if a singular statement appears in the long-range plan, it may have a comparative statement in the job description and the evaluation document. Therefore, two opportunities for comparative statements exist for each item in the long-range plan and the plan items are given a mathematical value of two. Figure 9 below shows a summary of these data and how in the last column "Total Comparative Statements" the number of items is doubled.

\section{Figure 9}

\begin{tabular}{|c|c|r|r|r|}
\hline Case\# & $\begin{array}{c}\text { Total } \\
\text { Items } \\
\text { from } \\
\text { Plan }\end{array}$ & $\begin{array}{c}\text { Comparative } \\
\text { Statements in Job } \\
\text { Description }\end{array}$ & $\begin{array}{c}\text { Comparative } \\
\text { Statements in } \\
\text { Evaluation } \\
\text { Documents }\end{array}$ & $\begin{array}{c}\text { Total Comparative } \\
\text { Statements }\end{array}$ \\
\hline 1 & 9 & $7 / 9-77.778 \%$ & $0 / 9$ & $7 / 18-39 \%$ \\
\hline 2 & 8 & $5 / 8-62.5 \%$ & Variable and Direct* & Variable and Direct* \\
\hline 3 & 6 & $3 / 6-50 \%$ & $0 / 6$ & $3 / 12-25 \%$ \\
\hline
\end{tabular}




\begin{tabular}{|c|c|c|c|c|}
\hline 4 & 9 & $1 / 9-11.111 \%$ & $0 / 9$ & $1 / 18-5.556 \%$ \\
\hline 5 & 6 & $5 / 6-83.333 \%$ & $2 / 5-33.33 \%$ & $7 / 12-58.333 \%$ \\
\hline 6 & 4 & $3 / 4-75 \%$ & $4 / 4-100 \%$ & $7 / 8-87.5 \%$ \\
\hline 7 & 11 & $4 / 11-36.36 \%$ & $0 / 11$ & $4 / 22-18.182 \%$ \\
\hline 8 & 4 & $3 / 4-75 \%$ & $2 / 4-50 \%$ & $5 / 8-62.5 \%$ \\
\hline 9 & 8 & $6 / 8-75 \%$ & $5 / 8-62.5 \%$ & $11 / 16-68.75 \%$ \\
\hline 10 & 6 & $3 / 6-50 \%$ & $0 / 6$ & $3 / 12-25 \%$ \\
\hline 11 & 9 & $3 / 9-33.333 \%$ & $1 / 9-11.111 \%$ & $4 / 18-22.222 \%$ \\
\hline 12 & 6 & $0 / 6$ & $0 / 6$ & $0 / 6$ \\
\hline 13 & 1 & $0 / 1$ & $0 / 1$ & $0 / 1$ \\
\hline 14 & 5 & $0 / 5$ & $0 / 5$ & $0 / 5$ \\
\hline 15 & 4 & $4 / 4-100 \%$ & $4 / 4-100 \%$ & $8 / 8-100 \%$ \\
\hline 16 & 6 & $5 / 6-83.333 \%$ & $3 / 6-50 \%$ & $8 / 12-66.667 \%$ \\
\hline 17 & 6 & $2 / 6-33.333 \%$ & $0 / 6$ & $2 / 12-16.667 \%$ \\
\hline 18 & 4 & $1 / 4-25 \%$ & $0 / 4$ & $1 / 8-12.5 \%$ \\
\hline 19 & 4 & $2 / 4-50 \%$ & $0 / 4$ & $2 / 8-25 \%$ \\
\hline 20 & 5 & $3 / 5-60 \%$ & $0 / 5$ & $3 / 10-30 \%$ \\
\hline 21 & 7 & $2 / 7-28.571 \%$ & $0 / 7$ & $2 / 14-14.286 \%$ \\
\hline 22 & 9 & $4 / 9-44.444 \%$ & $2 / 9-22.222 \%$ & $6 / 18-33.333 \%$ \\
\hline 23 & 12 & $5 / 12-41.667 \%$ & $0 / 12$ & $5 / 24-20.833 \%$ \\
\hline 24 & 5 & $0 / 5$ & $0 / 5$ & $0 / 5$ \\
\hline 25 & 7 & $4 / 7-57.143 \%$ & $4 / 7-57.143 \%$ & $8 / 14-57.143 \%$ \\
\hline 26 & 16 & $13 / 16-81.25 \%$ & $4 / 16-25 \%$ & $17 / 32-53.125 \%$ \\
\hline 27 & 8 & $3 / 8-37.5 \%$ & $4 / 8-50 \%$ & $7 / 16-43.75 \%$ \\
\hline 28 & 6 & $4 / 6-66.667 \%$ & $0 / 6$ & $4 / 12-33.333 \%$ \\
\hline 29 & 5 & $3 / 5-60 \%$ & $3 / 5-60 \%$ & $6 / 10-60 \%$ \\
\hline
\end{tabular}




\begin{tabular}{|l|c|r|r|r|}
\hline 30 & 13 & $3 / 13-23.077 \%$ & $6 / 13-46.154 \%$ & $9 / 26-34.615 \%$ \\
\hline 31 & 5 & $3 / 5-60 \%$ & $3 / 5-60 \%$ & $6 / 10-60 \%$ \\
\hline 32 & 5 & $3 / 5-60 \%$ & $1 / 5-20 \%$ & $4 / 10-40 \%$ \\
\hline
\end{tabular}

\section{TOTALS:}

32

219

$107-48.858 \%$

$48-21.918 \%$

$155 / 438-35.388 \%$

*This case is unique in that the evaluation document allows for direct comparison with the strategic plan. The first section of the evaluation document requires the evaluator to select items from the strategic plan and evaluate the administrator accordingly.

Another matter for discussion is the quality of the comparative statements themselves.

Virtually all of the comparative statements in these documents were categorical in nature.

That is, they generally relate to the same categories of things as the items in the plan but do not describe the items themselves. For example, in case one, item 4 the plan says, "...adapt curriculum over five years to make it thoroughly liberal arts in nature". The comparative item in the job description says, "Assist principals in supervision of staff, improvement of instruction, selection of curriculum...". This is a comparative statement to be sure, but in a general sense.

Some items are so general that they almost do not qualify as comparative. The weakest comparison made was in case 17, item 2. It says, "Program: (new programs, activities) develop 'applied technology', computer lab, drama, art, foreign language in middle school, resource room, greater mission/service, night school for computers". The comparative statement in the job description simply says, "Coordination of the total program". The use of the word program was considered as barely qualifying this item as comparative. It creates an umbrella for statements having to do with program development 
under which the specific goals in this item are covered. Broader statements such as "oversees the operation of the school" were not cited as comparative.

In contrast some of the language while categorical, still makes the implementation of items seem rather direct. The example below is case 15 , item four:

Figure 10

\begin{tabular}{|c|c|c|}
\hline $\begin{array}{c}\text { STATEMENT(S) } \\
\text { FROM LONG-RANGE } \\
\text { PLAN }\end{array}$ & $\begin{array}{l}\text { COMPARATIVE } \\
\text { STATEMENT(S) FROM } \\
\text { JOB DESCRIPTION }\end{array}$ & $\begin{array}{c}\text { COMPARATIVE } \\
\text { STATEMENT(S) FROM } \\
\text { EVALUATION } \\
\text { DOCUMENTS }\end{array}$ \\
\hline $\begin{array}{l}\text { To increase family enrollment } \\
\text { through recruitment and } \\
\text { retention by } 2 \% \text { per year for the } \\
\text { next three years. }\end{array}$ & $\begin{array}{l}\text { Oversee the process of } \\
\text { recruitment and retention of } \\
\text { students. }\end{array}$ & $\begin{array}{l}\text { Oversees the process of } \\
\text { recruitment and retention of } \\
\text { students. }\end{array}$ \\
\hline
\end{tabular}

In this example, the only difference between the item from the plan and the comparative statements in the job description and the evaluation document is the specific language related to the parameters $2 \%$ and three years. This is about as specific as a comparative statement can get without actually repeating the item verbatim.

There is one specific case that deserves some attention because it is unique in this sample. Case 2 has the only direct measurement of implementation of the long-range plan evidenced in an evaluation document. The approach is simple. The first page of the evaluation document has several blank lines for evaluation items. The instructions say that the evaluator is to supply items from the strategic plan, assign them a priority level, and evaluate the administrator as to his/her successful completion of each goal listed. This approach guarantees some level of assessment of whether or not the plan is being implemented by the administrator. 
Figure 11

\begin{tabular}{|c|c|c|}
\hline & \multicolumn{2}{|c|}{$\begin{array}{l}\text { PERFORMANCE MANAGEMENT AND DEVELOPMENT FORM } \\
\text { Manager's Copy }\end{array}$} \\
\hline \multicolumn{3}{|c|}{ Staff Member: } \\
\hline \multicolumn{3}{|l|}{ Title: } \\
\hline \multicolumn{3}{|c|}{ Manager/Evaluator: _ } \\
\hline \multicolumn{3}{|c|}{ Period covered by this review: } \\
\hline \multicolumn{3}{|c|}{ Part 1: GOALS } \\
\hline & \multicolumn{2}{|c|}{$\begin{array}{l}\text { Instructions: At the beginning of the evaluation period, list } 2 \text { to } 4 \text { major goals which are } \\
\text { important to accomplish. Determine the relative priority of each goal. At the end of the } \\
\text { evaluation period, describe the actual results achieved and check the rating that best } \\
\text { describes actual performance. }\end{array}$} \\
\hline \multicolumn{3}{|c|}{ Rating Key: } \\
\hline & & 3-Meets Most Expectations \\
\hline \multicolumn{3}{|c|}{ 2-Fully Meets Expectations } \\
\hline \multicolumn{3}{|l|}{ Priority } \\
\hline \multirow{2}{*}{1.} & \multirow{2}{*}{ Results Achieved: } & \\
\hline & & $1 \_2 \_3 \_4-$ \\
\hline \multirow[t]{3}{*}{2.} & Goal: & . \\
\hline & \multirow{2}{*}{ Results Achieved: } & \\
\hline & & $1 \_2 \_3 \_4$ \\
\hline
\end{tabular}

Technically, in a sample of 32 schools, case 2 represents $3.125 \%$ of the sample. When generalized to the population being studied (312 ACSI accredited schools) this should mean that in theory approximately ten schools would have such a system for measuring the implementation of their long-range plans. It is difficult however, to make that assertion 
based on one case in a study of thirty-two schools. What can be asserted is that it is possible based on this example to have direct and clear evidence of implementation of one's longrange plan based on the performance evaluation of the administrator.

\section{What the Data Suggest}

What these data suggest relative to the questions raised in the study is multi faceted. First of all, it seems as though there is more than a superficial interest among ACSI accredited schools in a process of strategic planning that is literal rather than symbolic. One hundred percent of the schools appear to be operating with a mission statement and $87.5 \%$ of the schools sampled had some kind of comparative statements in their documents relative to their long-range plan. Over 53\% (53.625\%) had separate statements in job descriptions and/or evaluation documents requiring the administrator to develop, maintain and implement a long-range plan. A solid majority of schools clearly are dealing with accountability and follow through based on the measurements set forth in this study.

It should be noted here that there were some respondents on the extremes. On question four of the survey which contained the phrase "formal implementation is not really necessary" two respondents did not respond D or SD. One (3.125\%) agreed and one was neutral. On the other hand, one school (3.125\%) demonstrated such a literal interest in implementation of their plan that they created an evaluation document on which items from the plan itself are to be written in.

The answers to the research questions raised in the study are as follows: 
1. What percentage of ACSI accredited schools have and can identify a long-range plan? Of the fifty schools responding to the survey nine (18\%) gave a "no plan" response. So $82 \%$ of the respondents had and identified plans.

2. In schools that have a long-range plan, are administrators being held accountable by their boards to implement that plan? The evidence suggests that significant numbers of them are.

a. Are there identifiable elements of the long-range plan in the job descriptions of administrators? Yes, such elements exist in $87.5 \%$ of the cases studied.

b. Are components of the plan included in the documents used to evaluate administrators? Yes. 50\% of the cases studied had such components.

c. Do ACSI school boards hold administrators responsible for carrying out long-range plans? Yes. All of the data in this study seem to point this way, but especially the fact that along with an $87.5 \%$ presence of comparative statements in the job descriptions and evaluation documents studied $53.125 \%$ of the job descriptions and evaluation documents contained statements specifically directing the administrator to oversee the long-range planning process.

Board chairs agree at a rate of $93.75 \%$ that administrators should be held accountable to implement long-range plans, though $31.25 \%$ suggest that the board is also responsible. This correlates positively with the fact that $87.5 \%$ of the cases studied showed evidence that administrators are indeed being held accountable on some level. However, it is important to note that the high number of statements in job descriptions and evaluation documents which fall into the same categories as items in the long-range plan does not guarantee that the board is holding the administrator directly responsible for implementing the plan. One 
must bear in mind that in the survey administrators underestimated the existence of comparative statements in job descriptions and evaluation documents. (See Figure 7, p. 54)

The only case in this study in which it is clear and obvious that the administrator is being held responsible for implementation of the plan is case number two. In this case the evaluation items are transferred directly from the plan by the evaluator.

In other cases the high correlation in items and the responses of administrators and board chairs seems to indicate that the intention to implement is there, but it is not obvious which schools actually do implement.

3. What is the correlation between ACSI accreditation and the development of long-range plans. The correlation is positive and fairly high in that $82 \%$ of all respondents had and could identify long-range plans.

It appears according to the data gathered in this study that the existence of a long-range plan does influence the way a school operates in $87.5 \%$ of all cases. That is there is an effort made to implement plans is evidenced in the documents submitted. One administrator in the survey portion of this study did agree with statement four that "formal implementation is not really necessary". That administrator (case 23) submitted a plan and documentation that showed comparative statements in 5 of 12 items on the job description (41.667\%) and no evaluation document (total comparative statements - 20.883\%). There was also a statement on the job description that said, "Establish 5-year and 10-year long-range goals." It does appear that the large majority of school boards believe enough in long-range planning to require the administration to develop and implement the plan. 


\section{CHAPTER 5}

\section{Implications of the Study}

In this chapter we will revisit the six issues raised in Chapter 2 and briefly discuss the implications related to each issue. First however, a significant observation must be mentioned concerning ACSI accredited schools. While $82 \%$ of the total respondents in the study identified a long-range plan, all ACSI accredited schools are required to have one. This means that $18 \%$ of the 312 ACSI accredited schools are operating outside the ACSI guidelines. One may view this as a high level of compliance but, it means that as many as 57 schools nation-wide may be out of compliance with ACSI standards according to these data.

One possible explanation for this would be that the administrators of these noncompliant schools were hired after the most recent accreditation visit and as a result are unaware of the plan. There are two problems associated with this view. One is that regardless of the administrator's date of hiring, the board should be aware of the plan and concerned with the issues of implementation, particularly in light of the $31.25 \%$ of board chairs who believe that the board is at least partly responsible for implementation of the plan. The other is that only one administrator of the nine who responded "no plan" gave a hiring date that was clearly after their most recent accreditation review.

The standard for having a long-range plan is that all accredited schools are to have one. Eighty-two percent is most, but it is obviously not all. ACSI may want to look into this further. 


\section{Mission}

One hundred percent of the administrators and the same number of board chairs responded that the schools in the study had mission statements upon which their goals, objectives, and plans were based. Even if one assumes a certain amount of inconsistency or even insincerity regarding the understanding of and the commitment to the school's mission, this is an impressive statistic. It is quite confluent with the concept of mission as described in the research literature (Bastin, 1996; Graham and Havlick, 1994).

Since mission is the starting point of organizational activity and the foundation on which the organization is said to be built, the importance of a study such as this one is elevated. The questions raised about implementation of goals and objectives which are based on mission become significant if for no other reason than that every single respondent has given assent to the concept of organizational goals flowing from a mission statement.

This study has focused on the fruit or product of the mission - goals - plan continuum, namely implementation of the plan. But, the clear commitment to mission revealed here suggests that schools carefully review their mission statements and ask significant questions in an effort to discover how mission driven or mission effective they really are.

\section{Key Result Areas}

One clear observation in this study was that a high number of items in job descriptions and evaluation documents are categorically the same as items in the long-range plan. That is to say, that while there is not a direct word by word comparison, the intent of the items puts the emphasis in the same place. 
This is significant in that it suggests that the schools in the study have been very thorough in identifying key result areas. In other words, they have shown a high level of consistency $(87.5 \%)$ in emphasizing certain key areas in which the organizations efforts and resources will be invested. This is foundational to the whole concept of key result areas. It raises an interesting question as to how self-aware these schools may be relative to their success in identifying key result areas. If school leaders are aware of this consistency from plans to documents or vice-versa they are likely to be reinforced in their understanding of how their time and effort should be applied at least in the general sense. This would be consistent with the research of Caradonio (1991) on key results planning.

\section{Goals and Objectives}

While this study reveals a high consistency in identifiable key result areas, the categorical (as opposed to directly comparative) nature of the comparative statements in the job descriptions and evaluation documents has other implications related to goals and objectives. Based on the fact that the quality of the comparisons varies from very general to somewhat more specific, one might call into question the efficacy of these comparative statements related to actually getting goals and objectives implemented. This is difficult to assess, however. The fact that so many categories of goals are comparative to so many statements in the related documents may indicate an effective process based on the consistency of the concerns expressed or the lack of direct comparison may suggest a process of goal development that needs to be more thorough and specific. 
When it comes to implementation, if the planning process is dynamic and inclusive in these schools the percentage of comparative elements in the documents might mean that all of the stakeholder groups are somewhat unified in their sense of mission and their understanding of the schools' goals. This could have the effect of asserting some informal influence on the administration to implement the plan. The power of this type of influence should not be underestimated since it grows out of a sense of unity and felt need.

In light of these observations it seems that when developing a long-range plan it is important to write the items (goals and objectives) in a way that is clear and shows a high level of consistency with the categories of job responsibilities and evaluation items. The greater this consistency and the clarity with which it is expressed, the clearer the mandate to the administrator who is to implement it.

Another way of saying this is that the more consistently a person's job description and performance evaluation documents relate to the goals and objectives of the school and the more clearly they are expressed to that person, the more likely that he/she will meet the expectations and achieve the goals and objectives of the school.

\section{Rationality}

The overwhelming acceptance of the rational model for planning revealed in these data implies that schools are probably open to revisiting and restructuring their plans but not necessarily looking for a significantly different model for planning.

The implication here is that since the classic or rational model has such broad acceptance among schools, that they should be open to engaging in rational processes such 
as comparing desired ends to achieved ends in order to make judgements as to their effectiveness.

The schools in this study do not appear to be very interested in exploring different concepts of how organizations achieve their goals outside the rational model. This is consistent with what most people associate with traditional patterns of western thought. It makes sense that Protestant Evangelical Christian schools would be more comfortable in a post-reformation rational philosophical structure than a post-existential or post-modern, nonrational philosophical structure. This means that the concepts of implementation, evaluation, and accountability should be viewed as a rational process as well.

\section{Rationality and Christian Thought}

The broad acceptance of the rational planning model among Christian school administrators and board chairs in this study raises the question of just how compatible this model is with Christian thought. Is the rational model also the "Christian model" for planning? If not, is there a Christian model?

It should be said that while the model presented in this research had universal acceptance among the respondents, and while the writer has reasoned that Christianity occupies a place in Western philosophy that is somewhat foundational to rational thought, there is nothing in this study to indicate that a rational planning model is equal to a Christian planning model. Beyond the basic Biblical proposition that God is a being of order who has created a world of cause and effect, (Ps. 19) there is no model for planning that would be distinctly Christian. Interestingly though, the Bible clearly admonishes the faithful to plan 
with humility and circumspection and submit those plans to God, realizing that one's life is not always predictable. (Prov. 16:9, 19:21; James 4:13-15) So, the uncertainty of the future and the limits of planning (whatever model is used) are obvious in biblical references to planning.

These uncertainties and limits of rationality are also obvious in the literature. Comments about the future of current decisions (Steiner, 1979; Williams, 1992), the limits of rationality (Hrebiniak and Joyce, 1981; Simon, 1997), and the dynamic nature of planning (Kallman, Reinhorth, Shapiro, 1981) abound in the literature and are duly noted in this paper.

However, the key to handling the fluid nature of a long-range plan as it evolves into an uncertain future is to entrust the plan to living individuals who will make appropriate adjustments in accordance with the organization's mission and goals. This explains why the CEO or administrator plays a vital role in the ongoing process of implementation, and why most boards feel that he/she and they are responsible to manage the plan.

It is interesting to note that in Christian theology, God is a living person to whom the plan is also entrusted. Perhaps an argument could be made that a "rational/personal" model for planning would be closer to a Christian planning model. It is not within the perview of this writer to say. The point here is simply that the rational model is not, in and of itself, a Christian planning model.

\section{Implementation and Administrative Assessment}

The crux of the issue in this project is implementation through the assessment or evaluation of the administrator. The administrator in these small, independent schools 
functions much as a CEO. She/he interacts with the board of directors and is responsible for general oversight of all school operations.

The basic question raised in this study related to whether evidence can be found that implementation is being required of administrators. The evidence sought and examined is contained in documents used to both direct and assess the activities of the administrator. Evidence of required implementation and evidence of accountability were clearly found. What remains open for some speculation is how effective schools are in carrying out their mission based on this high level of agreement on what should be done.

The rational approach, which appears to be universally accepted by the respondents would suggest that careful attention be given to the connections between the long-range plans and administrator performance. Administrators need direct and frequent feedback as to their progress in implementing the plans of their school. If the feedback is vague and general, then chances are the administrator may lack a clear sense of direction. If the feedback is clear and specific it is more likely that the administrator's sense of direction will be clear and specific.

This is not to say that administrators and boards will move lockstep through every aspect of the plan. Some of the feedback and evaluation will suggest modifications and adjustments. This is part of the dynamic nature of organizational life. What is expected in a rational planning system, however, is that organizational activities will be more efficient and effective in moving toward goals and objectives if an effective implementation and assessment process is in place.

In this study one system of administrator evaluation stood out as most clear and specific. It was case number two, in which the first set of items on the administrator 
evaluation are filled in by the evaluator from the long-range plan. This singular example stands out among these respondent schools as a rational and pragmatic way to assure an effective and direct evaluation of the implementation of long-range plans.

The genius of this model is its simplicity. By leaving the items for the evaluator to fill in and rank as to priority, this model allows for the kind of dynamic evolution that a working plan should have. It allows for a great deal of change in the plan without a lot of overhaul of the other documents. It also keeps the importance of the plan as a whole as well as its individual elements under continual scrutiny. This elevates the importance of implementing the overall plan while allowing for the rise or fall of the importance of individual goals. One of the strong conclusions of this researcher, therefore, is that schools would do well to use evaluation instruments that contain this feature.

\section{Administrative Leadership}

As mentioned above, the leadership paradigm in private schools in general, and particularly in those in this study, is that the administrator, often called headmaster or superintendent, functions and relates to the school board much as the CEO of a corporation would (Shrader, 1995; Caplow, 1983). This serves to heighten the importance of clear accountability to the local board, but it also makes the process quite streamlined by comparison to large "school systems". Local autonomy makes it possible for planning, implementation, and assessment to be done in a very direct and efficient way.

The current trend in public education toward site-based school management is indicative of the desire to streamline planning and stimulate local leadership and 
accountability. It is obvious in the research literature that both leadership and local stakeholder involvement play a significant role in whether an organization will reach its goals and fulfill its mission.

That a study should focus on administrators and their relationship to boards through job descriptions and evaluation documents is a logical step in light of the importance of administrative leadership to a successful planning process.

\section{Recommendations to the Profession}

Because the schools in this study are accredited by ACSI and the requirement exists that they have a long-range plan in place, closer attention should be given to the development, structure, quality and implementation strategies of the long-range plans in ACSI accredited schools.

Two methods could be used to accomplish this. First, materials could be developed and seminars offered on how to construct and implement an effective long-range plan. Secondly, chairs of visiting accreditation teams can be required to more carefully critique the long-range plans presented to them during the accreditation process. They could also be asked to examine administrators' job descriptions and evaluation documents as a measure of the school's intention to implement the long-range plan.

It was informally observed during this study that the language used in the plans of church-operated schools implied a hesitance to state clear objectives. Schools in this group tended to express what they hoped to accomplish if approved by the church's governing structure. Some work needs to be done with these schools so that their plans can be more 
intentional. Perhaps some pre-planning activities to clarify and strengthen the schools' autonomy within the church's structure would be helpful. ACSI may be able to play a role in this process by helping schools to establish an appropriate dialogue with the sponsoring church.

\section{Recommendations for Further Study}

This study has barely "scratched the surface" of the question of implementation of long-range plans in Christian schools. There is much more about the relationships of administrators to their boards that could be studied. There are also other ways to measure implementation besides basic evidence in job descriptions and evaluation documents.

The role of the board in this process, the qualities of administrative leadership, planning methods, and alternative methods of measuring accountability are all fertile ground for further study. Qualitative projects could be launched to intensively study relationships between boards, administrators, and other stakeholders.

The research in this area could also be broadened to include longitudinal studies of plans and their implementation, more Christian schools within or outside of ACSI, or comparative studies to a broader group of private schools.

The overwhelming preference for a rational planning model among the administrators and board chairs in this study raises an interesting question for further study. Is this planning model universally accepted in Christian schools, and if so, why? 


\section{Conclusion}

The basic truth discovered in this study is that Christian schools almost universally believe in the classic rational model for planning. Further, they have developed mission statements upon which they have attempted to base their objectives, goals, and plans.

There is strong evidence that boards are holding administrators accountable for implementing their plans, at least by category. It appears, however, that some thought could be given to developing methods for more clearly assessing plan implementation.

The school in case 2 seems to have discovered a simple, but very direct way to evaluate plan implementation while evaluating the administrator. This seems to be a logical conclusion in the rational planning model. There is a great deal of room for improvement and innovation among schools using the rational planning paradigm. 


\section{INDEX OF APPENDICES}

Letter to study schools $\ldots \ldots \ldots \ldots \ldots \ldots \ldots \ldots \ldots \ldots \ldots$ Page 78

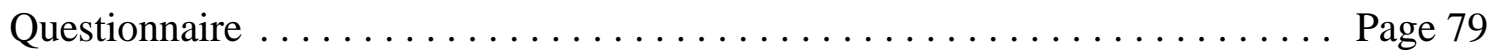

Follow up letter $\ldots \ldots \ldots \ldots \ldots \ldots \ldots \ldots \ldots \ldots \ldots \ldots \ldots \ldots \ldots \ldots \ldots \ldots \ldots$

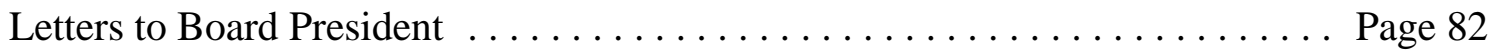

Board president survey $\ldots \ldots \ldots \ldots \ldots \ldots \ldots \ldots \ldots$ Page 84

Chart of Comparative Statements $\ldots \ldots \ldots \ldots \ldots \ldots \ldots \ldots \ldots \ldots \ldots \ldots \ldots \ldots$

Data Chart - Questionnaire/Survey $\ldots \ldots \ldots \ldots \ldots \ldots \ldots \ldots \ldots \ldots \ldots \ldots \ldots \ldots \ldots$ Page 125

Charts of Statement Responses $\ldots \ldots \ldots \ldots \ldots \ldots \ldots \ldots \ldots$ Page 128 


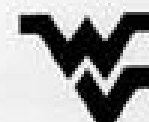

Education Administration

West Virginia University

College of Human Resources and Education

November 12, 1996

Dear Colleague,

As the head administrator of an ACSI accredited school, you have both insight and information that would be very meaningful to your colleagues across the nation. In light of that fact, I need to ask for your help. I am collecting information about long-range planning as part of my doctoral research project. The enclosed survey has been sent to the administrators of sixty-three ACSI aceredited schools with the permission of Jim Burdick, Executive Vice President of ACSI.

I am sure that like everyone in our profession, you are frequently asked to supply information for research projects. I would be very grateful if you would take time from your busy schedule to complete the enclosed two page survey and send the documents requested. $\mathrm{I}$ am hoping, in turn, to provide pertinent data to you and other ACSI administrators.

Your participation in this study is entirely voluntary and you do not have to respond to every item or question. I want to assure you that your responses will remain anonymous and confidentiality will be maintained.

Please note that in my request to see your evaluation document $\mathrm{I}$ am asking for a blank form, not a completed evaluation of your performance.

I have guessed at the return postage on the envelope provided by weighing my own documents and allowing for yours to be heavier. Please drop me a note if the postage is not cnough and I will reimburse you. Also, if you would like a copy of the complete study in addition to a summary of the data, just include that request when you return the survey.

Thanks so much for your help on this project. I wish you God's best in your ministry to students this year.

Sincerely,

Steve DeGeorge

District Representative for Tennessee

Southeast Region, ACSI

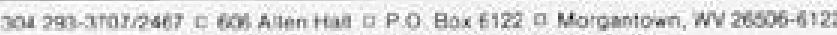

Equal Oppontanity / Attirmative Action Institution 


\section{QUESTIONNAIRE: LONG RANGE PLANNING}

PLEASE RETURN TO:Steven L. DeGeorge, 9426 Dutchtown Rd., Knoxville, TN. 37923

\section{THIS QUESTIONNAIRE HAS FOUR SECTIONS TO BE COMPLETED (A,B,C\&D)}

The definition of "long range plan" used in this research is applicable to the long range plan submitted to your accreditation committee. Human subjects used in this research will not be identified by name.

\section{A. Demographics}

1. What is your highest academic degree?

2. What educational certification(s) do you hold?

3. a. Years of experience in education at your present school

b. Years of Christian school administration experience at your present school

4. How many members are on your control board?

\section{B. Please answer the following questions}

1. Please give the date of your last ACSI accreditation review.

2. Does your school have a mission statement?

_ yes _ no

3. Does your school have a written long range plan?

4. How long has the plan been in place? (enter a number)

_ years _ months

5. How often is the plan reviewed?

Monthly _ Every six months _ Yearly _ Multi-yearly _ Not Reviewed

6. How are you held accountable for implementation of the plan? Elements of the plan are in my job description. Elements of the plan are in my performance evaluation.

— The board or a committee of the board evaluates implementation of the plan.

\section{Please express your level of agreement or disagreement with the following statements by circling one of the options below.}

$\mathbf{S A}=$ strongly agree. $\mathbf{A}=$ agree. $\mathbf{N}=$ neutral. $\mathbf{D}=$ disagree. $\mathbf{S D}=$ strongly disagree.

1. Schools should develop a written long range plan.

SA $\quad A \quad N \quad D \quad S D$

2. Long range plans should reflect the mission of the school.

SA $\quad$ A $\quad \mathrm{N} \quad \mathrm{D} \quad \mathrm{SD}$ 
3. Implementation of the long range plan is a major responsibility of the administration.

$$
\text { SA A N } \mathrm{N} \text { SD }
$$

4. The administration should be held accountable for implementation of the long range plan.
SA
A $\quad \mathrm{N}$
D SD

5. The exercise of planning helps to clarify the school's mission, but, formal implementation is not really necessary.
SA
A $\quad \mathrm{N}$
D SD

D. Please enclose copies of:

(1) your job description.

(2) Your performance evaluation document (blank).

(3) Your long range plan,

(4) Any other documentation of the implementation process (i.e. memos, minutes of committee meetings, etc.)

(5) the completed questionnaire in the envelope provided. 


\begin{tabular}{l} 
\\
\hline Steven L. DeGeorge \\
Headmaster \\
Brett D. Arthur \\
Principal, \\
Upper School \\
Jane R. Williams \\
Principal, \\
Lower School \\
Donna R. Poole \\
Guidance Counselor \\
Jim D. Geyer \\
Athletics/Facilities \\
Walter A. Clothier \\
Development Director
\end{tabular}

February 27, 1997

Dear Colleagues,

Several weeks ago I sent you a packet of materials related to a research project on long range plans. I do not yet have enough responses to start my analysis of the data.

If you could dig that material out and send back your response I would be eternally grateful. If you need a new packet, please give me a call.

Sincerely,

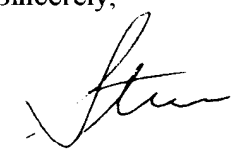

Steven L. DeGeorge

Headmaster

\section{Christian Academy of Knoxville \\ "And Jesus increased in wisdom and stature, and in favor with God and men." Luke 2:52}

\section{SLD:bjs}




\section{W \\ West Virginia University}

March 2, 1998

Dear Board President.

Several months ago your school paricipated in a study of long-range planning related to my doctoral dissertation. My committee and I feel that there is some data still needed relative to your views on plaming

Would you be kind enough to fill out the enclosed card and mail it back to me' Naturally, your participation is voluntary and your responses will remain anonymous

Thanks so much

Sincerely.

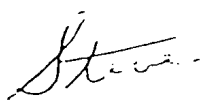

Steven L. DeGeorge

Headmaster

SLD:bjs 


\begin{tabular}{l} 
Peadmaster \\
\hline Brett D. Arthur \\
Principal, \\
Upper School \\
Jane R. Williams \\
Principal, \\
Lower School \\
Donna R. Poole \\
Guidance Counselor \\
Jim D. Geyer \\
AthleticsFacilities \\
Walter A. Clothier \\
Development Director
\end{tabular}

Development Director

\section{Christian Academy of Knoxville \\ "And Jesus increased in wisdom and stature, and in favor with God and men." Luke 2:52}

Dear Board President,

Would you do me a favor? I need to get a little more data on a research project in which your school participated.

Would you mind filling out the attached survey and faxing or mailing it back to me as soon as possible? Thanks so much.

In Christ

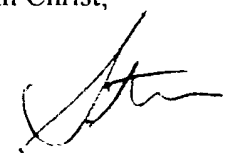

Steven L. DeGeorge

Headmaster

SLD:bjs

attachment 
In the introduction to this research I present a model for planning which I call the classic or rational model. It assumes that from the mission statement flow goals and objectives that form the basis for the plan, which has an implementation component and an evaluation component.

$$
\text { mission statement } \rightarrow \text { goals and objectives } \rightarrow \text { plan (implementation) }
$$

1. Do you believe that this is a valid model for planning?

$\square$ Yes $\quad \square$ No Comment

-

2. If you answered no to question \#1 do you subscribe to an alternative model for planning?

$\square$ Yes $\quad \square$ No Comment

3. Do you believe that the administrator should be held accountable for the implementation of the long-range plan?

$\square$ Yes $\quad \square$ No Comment 


\begin{tabular}{|c|c|c|}
\hline $\begin{array}{c}\text { STATEMENT(S) } \\
\text { FROM LONG-RANGE PLAN }\end{array}$ & $\begin{array}{c}\text { COMPARATIVE } \\
\text { STATEMENT(S) FROM JOB } \\
\text { DESCRIPTION }\end{array}$ & $\begin{array}{c}\text { COMPARATIVE } \\
\text { STATEMENT(S) FROM } \\
\text { EVALUATION } \\
\text { DOCUMENTS } \\
\end{array}$ \\
\hline \multicolumn{3}{|l|}{ SCHOOL \#1 } \\
\hline $\begin{array}{l}\text { Mission - Develop spiritually } \\
\text { mature, well-rounded, college } \\
\text { prepared students }\end{array}$ & $\begin{array}{l}\text { Provide leadership in the } \\
\text { accomplishment of the spiritual } \\
\text { mission of the school } \\
\text { - Direct the daily operation ... setting } \\
\text { the tone for a quality educational } \\
\text { program }\end{array}$ & $\begin{array}{l}\text { - No evaluation document } \\
\text { available. }\end{array}$ \\
\hline $\begin{array}{l}\text { - Teachers-hiring talented personnel } \\
\text { for new positions }\end{array}$ & $\begin{array}{l}\text { - Manage personnel affairs including } \\
\text { securing staff... }\end{array}$ & \\
\hline \multicolumn{3}{|l|}{$\begin{array}{l}\text { - developing those teachers already } \\
\text { employed } \\
\text { - } \text { further training } \\
\text { - other professional activities }\end{array}$} \\
\hline $\begin{array}{l}\text { - Curriculum-adapt curriculum over } \\
5 \text { years to make it more thoroughly } \\
\text { liberal arts in nature. } \\
\text { - expansion of science, math and the } \\
\text { arts. }\end{array}$ & $\begin{array}{l}\text { - Assist principals in supervision of } \\
\text { staff, improvement of instruction, } \\
\text { selection of curriculum.... }\end{array}$ & \\
\hline - Facilities - expand and upgrade & $\begin{array}{l}\text { - Oversee all projects such as building } \\
\text { programs... }\end{array}$ & \\
\hline $\begin{array}{l}\text { - Enrollment - retain more students } \\
\text { in secondary program by } \\
\text { enhancing quality and improving } \\
\text { admissions program }\end{array}$ & $\begin{array}{l}\text { - Establish and implement procedures } \\
\text { for the admission of students. } \\
\text {-...setting the tone for a quality } \\
\text { educational program }\end{array}$ & \\
\hline $\begin{array}{l}\text { - Management - greater emphasis on } \\
\text { development/marketing. } \\
\text { - hire appropriate staff }\end{array}$ & $\begin{array}{l}\text { - Assist in the development programs } \\
\text { - Manage personnel affairs including } \\
\text { securing staff... }\end{array}$ & \\
\hline $\begin{array}{l}\text { Tuition - gradual increases over } 5 \\
\text { years } \\
\text { - restructure payment schedule to } \\
\text { even out cash flow }\end{array}$ & & \\
\hline \multirow[t]{2}{*}{$\begin{array}{l}\text { - Financing- clear debts } \\
\text { - } \begin{array}{l}\text { seek grants / develop annual fund } \\
\text { giving }\end{array}\end{array}$} & $\begin{array}{l}\text { - Assist in the development } \\
\text { programs... }\end{array}$ & \\
\hline & - Provide long-range planning & \\
\hline \multicolumn{3}{|l|}{ SCHOOL \#1 TOTALS } \\
\hline 9 items & $\begin{array}{l}7 \text { items - } 77.778 \% \text { / 1-planning } \\
\text { statement }\end{array}$ & $\begin{array}{l}0 \text { items }-0 \% / \text { Total - } \\
38.889 \%\end{array}$ \\
\hline
\end{tabular}




\begin{tabular}{|c|c|c|}
\hline $\begin{array}{c}\text { STATEMENT(S) } \\
\text { FROM LONG-RANGE PLAN }\end{array}$ & $\begin{array}{c}\text { COMPARATIVE } \\
\text { STATEMENT(S) FROM JOB } \\
\text { DESCRIPTION }\end{array}$ & $\begin{array}{c}\text { COMPARATIVE } \\
\text { STATEMENT(S) FROM } \\
\text { EVALUATION } \\
\text { DOCUMENTS } \\
\end{array}$ \\
\hline $\begin{array}{l}\text { - Spiritual Life - formation of a } \\
\text { committee of the board to address: } \\
\text { Prayer, Church Involvement (of } \\
\text { families), Bible Curriculum, } \\
\text { Christian Service (for students), } \\
\text { Accountability. }\end{array}$ & $\begin{array}{l}\text { Establish a wholesome spiritual and } \\
\text { emotional atmosphere that will } \\
\text { characterize the school as a Christian } \\
\text { school. }\end{array}$ & $\begin{array}{l}\text { - Exceptional Case - See } \\
\text { below }\end{array}$ \\
\hline $\begin{array}{l}\text { Diversity - actively seek increased } \\
\text { minority presence and participation } \\
\text { in all areas of school life. }\end{array}$ & & \\
\hline $\begin{array}{l}\text { - Media Center - The library/media } \\
\text { centers will be equipped with } \\
\text { multiple computers, CD-ROM } \\
\text { technology, on-line networks, and } \\
\text { other current technology. }\end{array}$ & & \\
\hline $\begin{array}{l}\text { - Curriculum - five year curricular } \\
\text { and co-curricular review cycle. }\end{array}$ & $\begin{array}{l}\text { - Assume responsible leadership of the } \\
\text { school and its program, to act as } \\
\text { educational consultant to the board... }\end{array}$ & \\
\hline $\begin{array}{l}\text { - Early Childhood - complete review } \\
\text { of early childhood philosophy and } \\
\text { program. Form an early childhood } \\
\text { committee. }\end{array}$ & & \\
\hline $\begin{array}{l}\text { Facilities - maintain and improve } \\
\text { facilities by developing } \\
\text { professional site plan, an art } \\
\text { center/classroom addition, and a } \\
\text { feasibility study for a performing } \\
\text { arts center. }\end{array}$ & $\begin{array}{l}\text { - Be involved in the operation and } \\
\text { maintenance of the school plant. }\end{array}$ & \\
\hline $\begin{array}{l}\text { Marketing - develop a } \\
\text { comprehensive marketing plan. }\end{array}$ & $\begin{array}{l}\text { Have a key role in planning for the } \\
\text { future development of the school. }\end{array}$ & \\
\hline $\begin{array}{l}\text { - Growth - feasibility study of } \\
\text { enrollment growth. }\end{array}$ & $\begin{array}{l}\text { - Have a key role in planning for the } \\
\text { future development of the school. }\end{array}$ & $\begin{array}{l}\text { The evaluation documents } \\
\text { for the head administrator } \\
\text { and other staff are keyed to } \\
\text { the long-range plan by the } \\
\text { first section of the } \\
\text { document entitled "Part 1: } \\
\text { Goals". It states "Part } 1 \text { is } \\
\text { designed to document } \\
\text { goals to accomplish during } \\
\text { the coming year...These } \\
\text { individual goals are } \\
\text { intended to reflect and } \\
\text { reinforce the goals of } \\
\text { (school name) as outlined } \\
\text { in the Strategic Plan. }\end{array}$ \\
\hline
\end{tabular}




\begin{tabular}{|c|c|c|}
\hline $\begin{array}{c}\text { STATEMENT(S) } \\
\text { FROM LONG-RANGE PLAN }\end{array}$ & $\begin{array}{c}\text { COMPARATIVE } \\
\text { STATEMENT(S) FROM JOB } \\
\text { DESCRIPTION }\end{array}$ & $\begin{array}{c}\text { COMPARATIVE } \\
\text { STATEMENT(S) FROM } \\
\text { EVALUATION } \\
\text { DOCUMENTS } \\
\end{array}$ \\
\hline \multicolumn{3}{|l|}{ SCHOOL \#2 TOTALS } \\
\hline 8 items & 5 items $-62.5 \% / 1$-planning statement & $\begin{array}{l}\text { variable and direct / variable } \\
\text { planning statements }\end{array}$ \\
\hline \multicolumn{3}{|l|}{ SCHOOL \#3 } \\
\hline $\begin{array}{l}\text { Facilities: Add four classrooms } \\
\text { onto the H.S. wing and rest room } \\
\text { facilities...Rafter over existing } \\
\text { building. (17 specific } 1-5 \text { year } \\
\text { goals) }\end{array}$ & & $\begin{array}{l}\text { Administrator Evaluation: } \\
\text { The administrator is } \\
\text { evaluated by the school } \\
\text { board through observation, } \\
\text { teacher interviews, parent } \\
\text { interviews, and student } \\
\text { interviews. Results are } \\
\text { discussed during the April } \\
\text { board meeting without the } \\
\text { administrator present. } \\
\text { The administrator is also } \\
\text { evaluated by the staff } \\
\text { through a written } \\
\text { evaluation during April of } \\
\text { each year... }\end{array}$ \\
\hline $\begin{array}{l}\text { Finances: Increase staff salaries to } \\
\text { competitive level with area } \\
\text { government schools. Receive } \\
\text { significant interest from an } \\
\text { endowment fund. Ability to help } \\
\text { all needy students with tuition. } \\
\text { Debt free. (12 specific } 1-5 \text { year } \\
\text { goals) }\end{array}$ & $\begin{array}{l}\text { To be personally involved in } \\
\text { securing adequate gifts to } \\
\text { supplement tuition income. }\end{array}$ & \\
\hline \multicolumn{3}{|l|}{$\begin{array}{l}\text { Enrollment: All classes full with } \\
\text { kids from Christ-centered homes. } \\
\text { K-8: 350, 9-12: 200. (10 specific } \\
\text { 1-5 year goals) }\end{array}$} \\
\hline $\begin{array}{l}\text { - Curriculum: Quality education in } \\
\text { all areas of study. No paper back } \\
\text { books. Recognized throughout } \\
\text { S.W. Michigan for outstanding } \\
\text { Christian education. (11 specific 1- } \\
5 \text { year goals) }\end{array}$ & $\begin{array}{l}\text { To lead in the educational, spiritual } \\
\text { and disciplinary development of the } \\
\text { student body. }\end{array}$ & \\
\hline
\end{tabular}




\begin{tabular}{|c|c|c|}
\hline $\begin{array}{c}\text { STATEMENT(S) } \\
\text { FROM LONG-RANGE PLAN }\end{array}$ & $\begin{array}{c}\text { COMPARATIVE } \\
\text { STATEMENT(S) FROM JOB } \\
\text { DESCRIPTION }\end{array}$ & $\begin{array}{c}\text { COMPARATIVE } \\
\text { STATEMENT(S) FROM } \\
\text { EVALUATION } \\
\text { DOCUMENTS } \\
\end{array}$ \\
\hline $\begin{array}{l}\text { Personnel: All teachers ACSI and } \\
\text { State certified. All teachers have a } \\
\text { master's degree in their area of } \\
\text { ministry. All teaching only in } \\
\text { areas of expertise. (10 specific } 1-5 \\
\text { year goals) }\end{array}$ & $\begin{array}{l}\text { To develop a sound program for the } \\
\text { spiritual and academic growth of the } \\
\text { faculty. } \\
\text { To organize, motivate and manage } \\
\text { the faculty and staff to attain the } \\
\text { stated current and long-range } \\
\text { objectives of the school. }\end{array}$ & \\
\hline \multicolumn{3}{|l|}{$\begin{array}{l}\text { Extra-Curricular Activities: Offer } \\
\text { some college level courses in high } \\
\text { school that will transfer to colleges. } \\
\text { Provide a Bible institute during } \\
\text { evening hours for the community. } \\
\text { (7 specific } 1-5 \text { year goals) }\end{array}$} \\
\hline & $\begin{array}{l}\text { To present to the board in August of } \\
\text { each year (September, if first year of } \\
\text { contract) a clear statement of } \\
\text { objectives and goals for the school in } \\
\text { each of the following areas: a) } \\
\text { current-year goals b) two-year goals } \\
\text { c) five-year goals. } \\
\text { - To report to the board at three month } \\
\text { intervals (Nov., Feb., and May) on } \\
\text { progress toward these goals. }\end{array}$ & \\
\hline \multicolumn{3}{|l|}{ SCHOOL \#3 TOTALS } \\
\hline SCHOOL \#4 & 3 items - 50\% / 1-planning statement & 0 items $-0 \%$ / Total $-25 \%$ \\
\hline $\begin{array}{l}\text { This school's plan is a small part of } \\
\text { a larger church ministry plan. It is } \\
\text { also not a final draft. }\end{array}$ & & $\begin{array}{l}\text { - No written evaluation } \\
\text { items related to the plan or } \\
\text { planning }\end{array}$ \\
\hline - How many students? $5 \mathrm{yr}-10 \mathrm{yr}$ & $\begin{array}{l}\text { - Establish and implement procedures } \\
\text { for the admission of students. }\end{array}$ & \\
\hline - Weight Room & & \\
\hline - Lockers/Showers & & \\
\hline - Football Field \&Program & & \\
\hline $\begin{array}{l}\text { - Gymnatorium (stage/all purpose } \\
\text { floor) }\end{array}$ & & \\
\hline - Food Services & & \\
\hline - Satellite Schools & & \\
\hline
\end{tabular}




\begin{tabular}{|c|c|c|}
\hline $\begin{array}{c}\text { STATEMENT(S) } \\
\text { FROM LONG-RANGE PLAN }\end{array}$ & $\begin{array}{c}\text { COMPARATIVE } \\
\text { STATEMENT(S) FROM JOB } \\
\text { DESCRIPTION }\end{array}$ & \begin{tabular}{|c|} 
COMPARATIVE \\
STATEMENT(S) FROM \\
EVALUATION \\
DOCUMENTS \\
\end{tabular} \\
\hline \multicolumn{3}{|l|}{ - Band Room } \\
\hline \multicolumn{3}{|l|}{ - Day Care Facility } \\
\hline & - Provide long-range planning & \\
\hline \multicolumn{3}{|l|}{ SCHOOL \#4 TOTALS } \\
\hline 9 items & $\begin{array}{l}1 \text { item - } 11.111 \% \text { / } 1 \text { planning } \\
\text { statement }\end{array}$ & 0 items - 0\% / Total $5.556 \%$ \\
\hline \multicolumn{3}{|l|}{ SCHOOL \#5 } \\
\hline $\begin{array}{l}\text { This plan has a total of } 54 \text { goals } \\
\text { which fall into the following } \\
\text { categories: }\end{array}$ & & \\
\hline $\begin{array}{l}\text { - Curriculum: } 15 \text { goals including } \\
\text { expansion to reach more and } \\
\text { different types of students, help for } \\
\text { special needs, improving the arts, } \\
\text { foreign language and advance } \\
\text { placement. }\end{array}$ & $\begin{array}{l}\text { The headmaster shall submit plans } \\
\text { annually for developmental } \\
\text { programs in curriculum, staff, } \\
\text { buildings and equipment, and } \\
\text { publications as part of a long-range } \\
\text { plan for the total development of the } \\
\text { school. }\end{array}$ & \\
\hline $\begin{array}{l}\text { - Development: } 12 \text { goals including } \\
\text { better public relations, increased } \\
\text { marketing for enrollment, a capital } \\
\text { campaign, and improvement of } \\
\text { annual fund giving. }\end{array}$ & $\begin{array}{l}\text { The headmaster shall submit plans } \\
\text { annually for developmental } \\
\text { programs in curriculum, staff, } \\
\text { buildings and equipment, and } \\
\text { publications as part of a long-range } \\
\text { plan for the total development of the } \\
\text { school. }\end{array}$ & $\begin{array}{l}\text { Cooperates with the } \\
\text { director of development } \\
\text { and staff to plan and carry } \\
\text { out the most effective } \\
\text { program for the school, the } \\
\text { parents, the staff and } \\
\text { students as well as the } \\
\text { community serviced. }\end{array}$ \\
\hline $\begin{array}{l}\text { - Admin./Finance: } 8 \text { goals including } \\
\text { refinement of the budget process, } \\
\text { holding down tuition, } \\
\text { computerizing operations, better } \\
\text { internal communication and } \\
\text { accountability. }\end{array}$ & $\begin{array}{l}\text { He shall prepare an annual budget } \\
\text { for the consideration of the board. } \\
\text { He shall work with the finance } \\
\text { committee, the staff welfare } \\
\text { committee, and administrators in } \\
\text { preparing the budget. }\end{array}$ & $\begin{array}{l}\text { - Budget formulation and } \\
\text { adherence (preparation of } \\
\text { annual budget with staff } \\
\text { and finance committee) }\end{array}$ \\
\hline $\begin{array}{l}\text { Personnel: } 6 \text { goals including } \\
\text { improvement of the hiring process, } \\
\text { a "buddy system" for new staff, } \\
\text { improvement of in service training. }\end{array}$ & $\begin{array}{l}\text { Procurement of Personnel: The } \\
\text { Headmaster is responsible to contact, } \\
\text { interview with other administrators, } \\
\text { and recommend the hiring of staff to } \\
\text { the board. In carrying out this } \\
\text { function he shall follow the } \\
\text { established procedures of the board. }\end{array}$ & \\
\hline
\end{tabular}




\begin{tabular}{|c|c|c|}
\hline $\begin{array}{c}\text { STATEMENT(S) } \\
\text { FROM LONG-RANGE PLAN }\end{array}$ & $\begin{array}{c}\text { COMPARATIVE } \\
\text { STATEMENT(S) FROM JOB } \\
\text { DESCRIPTION }\end{array}$ & $\begin{array}{c}\text { COMPARATIVE } \\
\text { STATEMENT(S) FROM } \\
\text { EVALUATION } \\
\text { DOCUMENTS }\end{array}$ \\
\hline $\begin{array}{l}\text { Facilities: } 6 \text { goals including land } \\
\text { acquisition, construction, and } \\
\text { renovation. }\end{array}$ & $\begin{array}{l}\text { The headmaster shall submit plans } \\
\text { annually for developmental } \\
\text { programs in curriculum, staff, } \\
\text { buildings and equipment, and } \\
\text { publications as part of a long-range } \\
\text { plan for the total development of the } \\
\text { school. }\end{array}$ & \\
\hline $\begin{array}{l}\text { Outreach: } 6 \text { goals including greater } \\
\text { emphasis on prayer, evangelism } \\
\text { training, summer missions. }\end{array}$ & & \\
\hline \multicolumn{3}{|l|}{ SCHOOL \#5 TOTALS } \\
\hline 6 items & 5 items - $83.333 \%$ & $\begin{array}{l}2 \text { items - 33.333\% / Total } \\
58.333 \%\end{array}$ \\
\hline \multicolumn{3}{|l|}{ SCHOOL \#6 } \\
\hline $\begin{array}{l}\text { Education: Annual review of SAT } \\
\text { scores, strengths and weaknesses in } \\
\text { the curriculum. Evaluation of new } \\
\text { math and history curriculum } \\
\text { purchased this fall. Additional } \\
\text { technological advancements. Staff } \\
\text { recommendations and review. } \\
\text { Continue to convert overviews and } \\
\text { objectives into statements of } \\
\text { measurable outcomes throughout } \\
\text { the curriculum. }\end{array}$ & $\begin{array}{l}\text { The Administrator is responsible for } \\
\text { providing overall educational } \\
\text { leadership to the school. He is to } \\
\text { work in conjunction with the } \\
\text { education subcommittee of the board } \\
\text { in identifying curriculum needs and } \\
\text { in initiating a process of curriculum } \\
\text { review and selection. The } \\
\text { Administrator will keep himself } \\
\text { informed of developments and issues } \\
\text { in Christian education that have } \\
\text { bearing on the continuing growth } \\
\text { and vitality of the school. Nine } \\
\text { specific points follow }\end{array}$ & $\begin{array}{l}\text { - All items in this section are } \\
\text { preceded with the question, } \\
\text { to what extent does the } \\
\text { administrator...? } \\
\text { - Develop and implement a } \\
\text { curriculum, based upon the } \\
\text { school's philosophy of } \\
\text { education }\end{array}$ \\
\hline $\begin{array}{l}\text { - Building and Grounds: Major } \\
\text { renovation of parking and } \\
\text { pickup/delivery accommodations. } \\
\text { Update intercom and fire alarm } \\
\text { system. Research additional } \\
\text { building space opportunities. } \\
\text { Complete ground zero playground } \\
\text { installation. }\end{array}$ & & $\begin{array}{l}\text { Identify school program } \\
\text { needs - plant, facilities, } \\
\text { equipment, and supplies. }\end{array}$ \\
\hline $\begin{array}{l}\text { Development/Promotion: Plan and } \\
\text { execute auction, magazine sale. } \\
\text { Prepare video and brochures for } \\
\text { further promotion. Produce new } \\
\text { letterhead. Research grant money, } \\
\text { trusts, endowments. }\end{array}$ & $\begin{array}{l}\text { The Administrator should assist the } \\
\text { board in developing a vision for the } \\
\text { future by identifying the specific } \\
\text { needs of the school and proposing } \\
\text { plans to address those needs. }\end{array}$ & $\begin{array}{l}\text { Identify school program } \\
\text { needs... Develop long } \\
\text { range goals/planning. }\end{array}$ \\
\hline
\end{tabular}




\begin{tabular}{|c|c|c|}
\hline $\begin{array}{c}\text { STATEMENT(S) } \\
\text { FROM LONG-RANGE PLAN }\end{array}$ & $\begin{array}{c}\text { COMPARATIVE } \\
\text { STATEMENT(S) FROM JOB } \\
\text { DESCRIPTION }\end{array}$ & $\begin{array}{c}\text { COMPARATIVE } \\
\text { STATEMENT(S) FROM } \\
\text { EVALUATION } \\
\text { DOCUMENTS } \\
\end{array}$ \\
\hline \multirow[t]{2}{*}{$\begin{array}{l}\text { Finance: Oversee current budget. } \\
\text { Gather information and plan 1997- } \\
98 \text { budget. Oversee payments and } \\
\text { financial aid. Plan for teacher } \\
\text { salary and benefit improvement. } \\
\text { Recommend further financial needs } \\
\text { of the school. }\end{array}$} & $\begin{array}{l}\text { The Administrator is the resource } \\
\text { manager for the school, responsible } \\
\text { for developing and administering the } \\
\text { budget along with the board. Eight } \\
\text { specific points follow including } \\
\text { long-range planning. }\end{array}$ & $\begin{array}{l}\text { - Assist in preparing a clear } \\
\text { and accurate annual budget } \\
\text { for presentation to the } \\
\text { board. }\end{array}$ \\
\hline & $\begin{array}{l}\text { The Administrator should assist the } \\
\text { board in developing a vision for the } \\
\text { future by identifying the specific } \\
\text { needs of the school and proposing } \\
\text { plans to address those needs. }\end{array}$ & $\begin{array}{l}\text { - Develop long range } \\
\text { goals/planning }\end{array}$ \\
\hline \multicolumn{3}{|l|}{ SCHOOL \#6 TOTALS } \\
\hline 4 items & 3 items $-75 \% / 1$ planning statement & $\begin{array}{l}4 \text { items } 100 \% \text { / } 1 \text { planning } \\
\text { statement / Total }-87.5 \%\end{array}$ \\
\hline \multicolumn{3}{|l|}{ SCHOOL \#7 } \\
\hline $\begin{array}{l}\text {...9 Major areas for planning, } \\
\text { action, and assignment to } \\
\text { committees: }\end{array}$ & & $\begin{array}{l}\text { no performance evaluation } \\
\text { document available. } \\
\text { Various forms used. }\end{array}$ \\
\hline $\begin{array}{l}\text { - Promote school image in the } \\
\text { community -- PR Committee }\end{array}$ & $\begin{array}{l}\text { Represent the school at parent, } \\
\text { church, and community groups as } \\
\text { able. }\end{array}$ & \\
\hline $\begin{array}{l}\text { - Promote (school name) through } \\
\text { various PR tools -- PR Committee }\end{array}$ & $\begin{array}{l}\text { - Oversee and the development of an } \\
\text { efficient public relations program }\end{array}$ & \\
\hline \multicolumn{3}{|l|}{$\begin{array}{l}\text { Plan for continued building space } \\
\text { within or outside the church as } \\
\text { needed. Current needs are being } \\
\text { met -- Long Range Planning } \\
\text { Committee }\end{array}$} \\
\hline $\begin{array}{l}\text { - Expand existing budget with } \\
\text { supplemental income -- Finance } \\
\text { Committee }\end{array}$ & $\begin{array}{l}\text { - The principal shall seek to establish a } \\
\text { broad financial base for the school } \\
\text { through various means (i.e. } \\
\text { scholarship fund, etc.) }\end{array}$ & \\
\hline $\begin{array}{l}\text { - Increase salaries and benefits -- } \\
\text { Finance and Personnel Committees }\end{array}$ & $\begin{array}{l}\text { The principal shall make annual } \\
\text { recommendations for improving } \\
\text { salaries and benefits. }\end{array}$ & \\
\hline $\begin{array}{l}\text { - Improve and encourage the } \\
\text { spiritual dimension of the School } \\
\text { Committee -- School Committee } \\
\text { Chairman }\end{array}$ & & \\
\hline
\end{tabular}




\begin{tabular}{|c|c|c|}
\hline $\begin{array}{c}\text { STATEMENT(S) } \\
\text { FROM LONG-RANGE PLAN }\end{array}$ & $\begin{array}{c}\text { COMPARATIVE } \\
\text { STATEMENT(S) FROM JOB } \\
\text { DESCRIPTION }\end{array}$ & $\begin{array}{c}\text { COMPARATIVE } \\
\text { STATEMENT(S) FROM } \\
\text { EVALUATION } \\
\text { DOCUMENTS } \\
\end{array}$ \\
\hline $\begin{array}{l}\text { - Increase the dedication of the } \\
\text { school committee to God's work in } \\
\text { the school -- School Committee }\end{array}$ & & \\
\hline $\begin{array}{l}\text { - Consider the advantages and } \\
\text { disadvantages of becoming a } \\
\text { separate entity from the sponsoring } \\
\text { church -- Long Range Planning } \\
\text { Committee }\end{array}$ & & \\
\hline $\begin{array}{l}\text { Increase parent's perception of the } \\
\text { value of their child's education at } \\
\text { (school name) -- Finance } \\
\text { Committee }\end{array}$ & & \\
\hline $\begin{array}{l}\text { The administration will be } \\
\text { involved in the planning and } \\
\text { implementation of each of these } \\
\text { goals. }\end{array}$ & & \\
\hline \multicolumn{3}{|l|}{ SCHOOL \#7 TOTALS } \\
\hline 11 items & 4 items - $36.136 \%$ & $\begin{array}{l}0 \text { items }-0 \% / \text { Total - } \\
18.182 \%\end{array}$ \\
\hline
\end{tabular}




\begin{tabular}{|c|c|c|}
\hline $\begin{array}{c}\text { STATEMENT(S) } \\
\text { FROM LONG-RANGE PLAN }\end{array}$ & $\begin{array}{c}\text { COMPARATIVE } \\
\text { STATEMENT(S) FROM JOB } \\
\text { DESCRIPTION }\end{array}$ & $\begin{array}{c}\text { COMPARATIVE } \\
\text { STATEMENT(S) FROM } \\
\text { EVALUATION } \\
\text { DOCUMENTS }\end{array}$ \\
\hline \multicolumn{3}{|l|}{ SCHOOL \#8 } \\
\hline $\begin{array}{l}\text { Spiritual and Academic } \\
\text { Curriculum: To provide a Christian } \\
\text { view that is integrated throughout } \\
\text { the curriculum. To offer an } \\
\text { academically challenging program } \\
\text { to students. And to combine the } \\
\text { Christian view and academics to } \\
\text { develop Christian leadership for } \\
\text { our churches and country. (2 sub- } \\
\text { goals with } 26 \text { action steps) }\end{array}$ & $\begin{array}{l}\text { To implement the written mission } \\
\text { statement } \\
\text {...to continuously improve the } \\
\text { spiritual excellence and character } \\
\text { development of students toward that } \\
\text { of Christ } \\
\text {-..To provide curriculum and } \\
\text { environment that is academically } \\
\text { excellent... }\end{array}$ & $\begin{array}{l}\text { - To continuously improve } \\
\text { the spiritual excellence and } \\
\text { character development of } \\
\text { students toward that of } \\
\text { Christ. } \\
\text { - To provide a curriculum } \\
\text { and environment that is } \\
\text { academically excellent and } \\
\text { prepares students for } \\
\text { college. }\end{array}$ \\
\hline $\begin{array}{l}\text { Extra-Curricular Activities: To } \\
\text { provide a wide range of activities } \\
\text { that support the school's mission } \\
\text { and at the same time } \\
\text { encourages(sic) the development of } \\
\text { skills and talents of individual } \\
\text { students. ( } 2 \text { sub-goals with } 8 \text { action } \\
\text { steps) }\end{array}$ & & \\
\hline $\begin{array}{l}\text { Faculty: To recruit and retain a } \\
\text { staff who models and generates an } \\
\text { environment of spiritual and } \\
\text { academic excellence. ( } 2 \text { sub-goals } \\
\text { with } 11 \text { action steps) }\end{array}$ & $\begin{array}{l}\text { To hire and retain and train school } \\
\text { staff. }\end{array}$ & $\begin{array}{l}\text { - To hire retain and train } \\
\text { school staff. }\end{array}$ \\
\hline \multirow[t]{2}{*}{$\begin{array}{l}\text { Enrollment and Retention: To } \\
\text { identify, enroll and retain students } \\
\text { who are seeking a conservative, } \\
\text { Christian environment and who are } \\
\text { wiling to participate in an } \\
\text { academically inclined curriculum. } \\
\text { ( } 2 \text { sub-goals with } 11 \text { action steps) }\end{array}$} & $\begin{array}{l}\text { To lead in overall development and } \\
\text { marketing of the school } \\
\text {-..to recruit and retain students. }\end{array}$ & \\
\hline & $\begin{array}{l}\text { - To develop and implement plans for } \\
\text { the school } \\
\text {-..to maintain a long term strategic } \\
\text { plan and planning process } \\
\text { - ..to establish annual goals for the } \\
\text { school. }\end{array}$ & $\begin{array}{l}\text { To maintain a long term } \\
\text { strategic plan and planning } \\
\text { process. }\end{array}$ \\
\hline \multicolumn{3}{|l|}{ SCHOOL \#8 TOTALS } \\
\hline 4 items & 3 items $-75 \%$ / 1 planning statement & $\begin{array}{l}2 \text { items - } 50 \% \text { / } 1 \text { planning } \\
\text { statement / Total }-62.5 \%\end{array}$ \\
\hline
\end{tabular}




\begin{tabular}{|c|c|c|}
\hline $\begin{array}{c}\text { STATEMENT(S) } \\
\text { FROM LONG-RANGE PLAN }\end{array}$ & $\begin{array}{c}\text { COMPARATIVE } \\
\text { STATEMENT(S) FROM JOB } \\
\text { DESCRIPTION }\end{array}$ & $\begin{array}{c}\text { COMPARATIVE } \\
\text { STATEMENT(S) FROM } \\
\text { EVALUATION } \\
\text { DOCUMENTS } \\
\end{array}$ \\
\hline \multicolumn{3}{|l|}{ SCHOOL \#9 } \\
\hline $\begin{array}{l}\text { Enrollment goals. Strategy for } \\
\text { continued growth is to build from } \\
\text { the bottom up. Our focus will be } \\
\text { twofold: 1. Maintain current } \\
\text { students. 2. Build up Preschool and } \\
\text { Kindergarten departments. }\end{array}$ & & \\
\hline $\begin{array}{l}\text { Accreditation. Committees will be } \\
\text { established for the Accreditation } \\
\text { self-study that will continue for the } \\
\text { purpose of evaluating, research, } \\
\text { and making proposals at the } \\
\text { request of the School Board. }\end{array}$ & $\begin{array}{l}\text { - To know requirements and } \\
\text { procedures for accreditation. }\end{array}$ & $\begin{array}{l}\text { Knows the requirements } \\
\text { and procedures for } \\
\text { accreditation. }\end{array}$ \\
\hline $\begin{array}{l}\text { - Facilities. } 9 \text { expanded or additional } \\
\text { classrooms needed by } 97-98 \text { school } \\
\text { year. } 4 \text { other specific needs } \\
\text { identified. }\end{array}$ & $\begin{array}{l}\text { - Shall submit plans annually for } \\
\text { developmental programs in } \\
\text { curriculum, building, equipment, } \\
\text { and staffing as part of a strategic } \\
\text { long-term plan for total development } \\
\text { of the school. }\end{array}$ & \\
\hline $\begin{array}{l}\text { - Equipment. } 9 \text { specific pieces of } \\
\text { equipment identified. }\end{array}$ & $\begin{array}{l}\text { - Shall submit plans annually for } \\
\text { developmental programs in } \\
\text { curriculum, building, equipment, } \\
\text { and staffing as part of a strategic } \\
\text { long-term plan for total development } \\
\text { of the school. }\end{array}$ & $\begin{array}{l}\text { - Shall submit plans } \\
\text { annually for developmental } \\
\text { programs in curriculum, } \\
\text { building, equipment, and } \\
\text { staffing as part of a } \\
\text { strategic long-term plan for } \\
\text { total development of the } \\
\text { school. }\end{array}$ \\
\hline $\begin{array}{l}\text { - Curriculum. } 13 \text { specific curricular } \\
\text { goals listed. }\end{array}$ & $\begin{array}{l}\text { - Shall submit plans annually for } \\
\text { developmental programs in } \\
\text { curriculum, building, equipment, } \\
\text { and staffing as part of a strategic } \\
\text { long-term plan for total development } \\
\text { of the school. }\end{array}$ & $\begin{array}{l}\text { - Submits plans annually for } \\
\text { developmental programs in } \\
\text { curriculum, building, } \\
\text { equipment, and staffing as } \\
\text { part of a strategic long- } \\
\text { term plan for total } \\
\text { development of the school. }\end{array}$ \\
\hline $\begin{array}{l}\text { Additional Personnel needs. } 16 \\
\text { new or expanded positions listed as } \\
\text { goals. }\end{array}$ & $\begin{array}{l}\text { - Shall submit plans annually for } \\
\text { developmental programs in } \\
\text { curriculum, building, equipment, } \\
\text { and staffing as part of a strategic } \\
\text { long-term plan for total development } \\
\text { of the school. }\end{array}$ & $\begin{array}{l}\text { - Submits plans annually for } \\
\text { developmental programs in } \\
\text { curriculum, building, } \\
\text { equipment, and staffing as } \\
\text { part of a strategic long- } \\
\text { term plan for total } \\
\text { development of the school. }\end{array}$ \\
\hline
\end{tabular}




\begin{tabular}{|c|c|c|}
\hline $\begin{array}{c}\text { STATEMENT(S) } \\
\text { FROM LONG-RANGE PLAN }\end{array}$ & $\begin{array}{c}\text { COMPARATIVE } \\
\text { STATEMENT(S) FROM JOB } \\
\text { DESCRIPTION }\end{array}$ & $\begin{array}{c}\text { COMPARATIVE } \\
\text { STATEMENT(S) FROM } \\
\text { EVALUATION } \\
\text { DOCUMENTS } \\
\end{array}$ \\
\hline $\begin{array}{l}\text { - Development. } 10 \text { specific goals } \\
\text { listed, including staffing. }\end{array}$ & $\begin{array}{l}\text { Shall submit plans annually for } \\
\text { developmental programs in } \\
\text { curriculum, building, equipment, } \\
\text { and staffing as part of a strategic } \\
\text { long-term plan for total development } \\
\text { of the school. }\end{array}$ & $\begin{array}{l}\text { - Submits plans annually for } \\
\text { developmental programs in } \\
\text { curriculum, building, } \\
\text { equipment, and staffing as } \\
\text { part of a strategic long- } \\
\text { term plan for total } \\
\text { development of the school. }\end{array}$ \\
\hline $\begin{array}{l}\text { - General. } 4 \text { specific goals including } \\
\text { (school name) Staff Annual } \\
\text { Review. }\end{array}$ & & \\
\hline \multicolumn{3}{|l|}{ SCHOOL \#9 TOTALS } \\
\hline 8 items & 6 items $-75 \%$ & $\begin{array}{l}5 \text { items }-62.5 \% / \text { Total - } \\
68.75 \%\end{array}$ \\
\hline \multicolumn{3}{|l|}{ SCHOOL \#10 } \\
\hline $\begin{array}{l}\text { - Growth and development (Number } \\
\text { of students and how much money } \\
\text { do we need): } 9 / 97-350 \text { students. } \\
\text { restructure grade divisions to } \\
\text { include a middle school. }\end{array}$ & & $\begin{array}{l}\text { - No evaluation document } \\
\text { available. }\end{array}$ \\
\hline $\begin{array}{l}\text { - Upgrade Curriculum: determine } \\
\text { which electives to offer; use } \\
\text { faculty in areas of training and } \\
\text { ability; institute AP English and } \\
\text { Calculus; define educational } \\
\text { philosophy; establish core } \\
\text { curriculum; use financial and } \\
\text { personnel resources in a planned } \\
\text { way. }\end{array}$ & $\begin{array}{l}\text { Assist principals in supervision of } \\
\text { staff, improvement of instruction, } \\
\text { selection of curriculum, and } \\
\text { administration of discipline } \\
\text { procedures as appropriate. }\end{array}$ & \\
\hline $\begin{array}{l}\text { Teacher Development: develop } \\
\text { master teacher program; } \\
\text { restructure salary scale; develop in } \\
\text { service and seminar attendance } \\
\text { plan. }\end{array}$ & $\begin{array}{l}\text { Assist principals in supervision of } \\
\text { staff, improvement of instruction, } \\
\text { selection of curriculum, and } \\
\text { administration of discipline } \\
\text { procedures as appropriate. }\end{array}$ & \\
\hline $\begin{array}{l}\text { PR, Image, Marketing (Building } \\
\text { awareness, providing information): } \\
\text { cultivate relationships with Trinity, } \\
\text { Crosscurrents and Glacier } \\
\text { Christian Schools. Develop an } \\
\text { admission packet that is a } \\
\text { promotion piece as well. }\end{array}$ & $\begin{array}{l}\text { - Coordinate the public relations } \\
\text { programs of the school including the } \\
\text { development of brochures, media } \\
\text { releases, etc. }\end{array}$ & \\
\hline
\end{tabular}




\begin{tabular}{|c|c|c|}
\hline $\begin{array}{c}\text { STATEMENT(S) } \\
\text { FROM LONG-RANGE PLAN }\end{array}$ & $\begin{array}{c}\text { COMPARATIVE } \\
\text { STATEMENT(S) FROM JOB } \\
\text { DESCRIPTION }\end{array}$ & $\begin{array}{c}\text { COMPARATIVE } \\
\text { STATEMENT(S) FROM } \\
\text { EVALUATION } \\
\text { DOCUMENTS } \\
\end{array}$ \\
\hline $\begin{array}{l}\text { Board Strengthening (What we } \\
\text { need to do to bring the board into } \\
\text { alignment with the needs): } \\
\text { increase board membership. } \\
\text { Establish (working) standing } \\
\text { committees. Review and revise } \\
\text { Constitution and By-laws. }\end{array}$ & & \\
\hline \multicolumn{3}{|l|}{$\begin{array}{l}\text { Organization, Administration } \\
\text { (what we need to fix or change } \\
\text { internally. }\end{array}$} \\
\hline & $\begin{array}{l}\text { Collaborate with the board to } \\
\text { provide long range planning. }\end{array}$ & \\
\hline \multicolumn{3}{|l|}{ SCHOOL \#10 TOTALS } \\
\hline 6 items & 3 items $-50 \%$ / 1 planning statement & 0 items $-0 \% /$ Total $-25 \%$ \\
\hline \multicolumn{3}{|l|}{ SCHOOL \#11 } \\
\hline 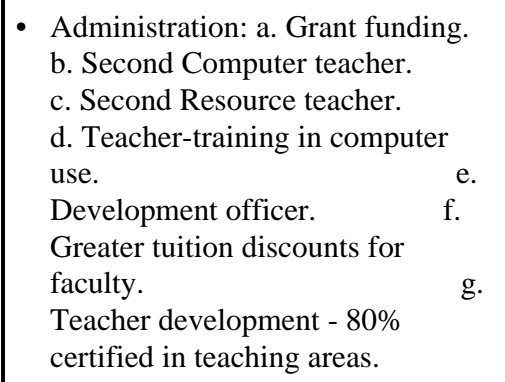 & $\begin{array}{l}\text { - Responsible to develop a sound } \\
\text { program for the spiritual and } \\
\text { professional in-service growth of the } \\
\text { faculty. } \\
\text { - Responsible for interviewing and } \\
\text { recruiting a quality faculty and staff. } \\
\text { - Responsible to promote individual } \\
\text { programs of professional growth for } \\
\text { the faculty and staff. }\end{array}$ & $\begin{array}{l}\text { - Recruits and hires good } \\
\text { personnel }\end{array}$ \\
\hline $\begin{array}{l}\text { - After School Care: a. Enrichment. } \\
\text { b. } 2 \& 3 \text { year old day care. }\end{array}$ & & \\
\hline $\begin{array}{l}\text { Athletics: a. Elementary program } \\
\text { (grades 1-4). b. Girls soccer. c. } \\
\text { Competition for national awards. d. } \\
\text { Athletics take the place of a P.E. } \\
\text { class during the day. e. Outdoor } \\
\text { netting facilities. }\end{array}$ & & \\
\hline $\begin{array}{l}\text { - Computers: Has an attached five- } \\
\text { year plan with five major goals and } \\
14 \text { specific objectives, which } \\
\text { address both student and staff } \\
\text { computing. }\end{array}$ & & \\
\hline
\end{tabular}




\begin{tabular}{|c|c|c|}
\hline $\begin{array}{c}\text { STATEMENT(S) } \\
\text { FROM LONG-RANGE PLAN }\end{array}$ & $\begin{array}{c}\text { COMPARATIVE } \\
\text { STATEMENT(S) FROM JOB } \\
\text { DESCRIPTION }\end{array}$ & $\begin{array}{c}\text { COMPARATIVE } \\
\text { STATEMENT(S) FROM } \\
\text { EVALUATION } \\
\text { DOCUMENTS } \\
\end{array}$ \\
\hline 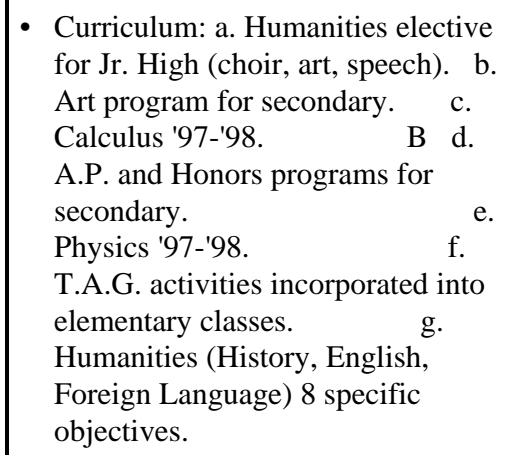 & $\begin{array}{l}\text { - Responsible to lead the staff in } \\
\text { continuous curriculum development. }\end{array}$ & \\
\hline 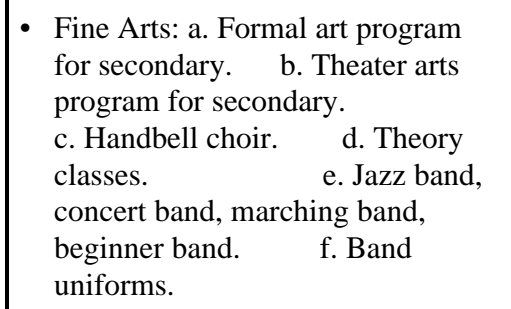 & $\begin{array}{l}\text { - Responsible to lead the staff in } \\
\text { continuous curriculum development. }\end{array}$ & \\
\hline $\begin{array}{l}\text { Parents: a. Computer training. b. } \\
\text { Parent training. }\end{array}$ & & \\
\hline $\begin{array}{l}\text { - Physical Plant: a. Fine Arts } \\
\text { Building. b. Expand library c. } \\
\text { Expand cafeteria. d. Showers for } \\
\text { gym. e. Expand gym. f. } \\
\text { New computer lab. g. New } \\
\text { van/or step van. }\end{array}$ & & \\
\hline \multicolumn{3}{|l|}{ 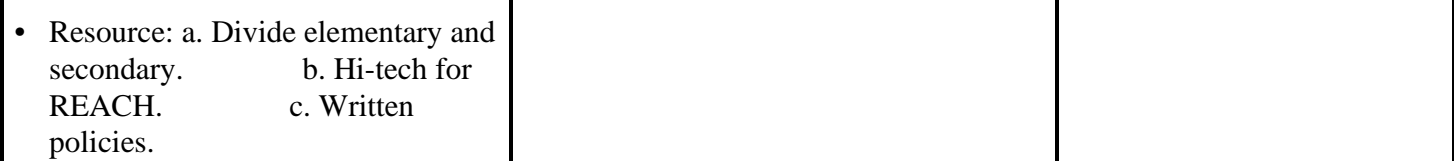 } \\
\hline & $\begin{array}{l}\text { Maintain a valid five-year plan for } \\
\text { the development of the school. } \\
\text { Responsible to provide the school } \\
\text { board with specific information for } \\
\text { long-range planning. }\end{array}$ & \\
\hline \multicolumn{3}{|l|}{ SCHOOL \#11 TOTALS } \\
\hline 9 items & $\begin{array}{l}3 \text { items - } 33.333 \% \text { / } 1 \text { planning } \\
\text { statement }\end{array}$ & $\begin{array}{l}1 \text { item }-11.111 \% \text { / Total - } \\
22.222 \%\end{array}$ \\
\hline
\end{tabular}




\begin{tabular}{|c|c|c|}
\hline $\begin{array}{c}\text { STATEMENT(S) } \\
\text { FROM LONG-RANGE PLAN }\end{array}$ & $\begin{array}{c}\text { COMPARATIVE } \\
\text { STATEMENT(S) FROM JOB } \\
\text { DESCRIPTION }\end{array}$ & $\begin{array}{c}\text { COMPARATIVE } \\
\text { STATEMENT(S) FROM } \\
\text { EVALUATION } \\
\text { DOCUMENTS } \\
\end{array}$ \\
\hline \multicolumn{3}{|l|}{ SCHOOL \#12 } \\
\hline $\begin{array}{l}\text { Items in this plan appear to be } \\
\text { listed in the same way that they are } \\
\text { assigned for implementation. The } \\
\text { prefixes seem to indicate who is } \\
\text { responsible. (HS=high school staff, } \\
\text { Brd=board) }\end{array}$ & $\begin{array}{l}\text { There is no clear correlation between } \\
\text { this plan and the superintendent's } \\
\text { (administrator's) job description. }\end{array}$ & $\begin{array}{l}\text { While a few basic } \\
\text { categories match (i.e. } \\
\text { hiring, decision making, } \\
\text { guiding instruction) there } \\
\text { is no apparent correlation } \\
\text { between the plan and this } \\
\text { evaluation form. }\end{array}$ \\
\hline $\begin{array}{l}\text { - Adm.: } 1 . \text { in depth study of } \\
\text { graduates. } 2 \text {. Increased staff for } \\
\text { increased enrollment. } 3 \text {. Research } \\
\text { for grants/sch. } 4 \text {. Additional } \\
\text { computer and printer for student } \\
\text { use in library. } 5 \text {. CD Rom for } \\
\text { library usage. } 6 \text {. Foreign country } \\
\text { geography books for library. } 7 . \\
\text { Additional first-aid and CPR } \\
\text { training for staff. 8. Replacement } \\
\text { of van with newer and larger } \\
\text { model. }\end{array}$ & & \\
\hline $\begin{array}{l}\text { Adm/Brd: 1. Hire full time music } \\
\text { teacher. 2. Locker room, rest room } \\
\text { addition completed as planned. } 3 \text {. } \\
\text { Middle school facility. 4. Dental } \\
\text { ins. for staff. 5. Newer desks for jr. } \\
\text { hi. }\end{array}$ & & \\
\hline $\begin{array}{l}\text { - All: 1. Curriculum articulation. } 2 . \\
\text { Additional audio/visual materials. }\end{array}$ & & \\
\hline $\begin{array}{l}\text { - Elem: Evaluate new Bible } \\
\text { curriculum }\end{array}$ & & \\
\hline $\begin{array}{l}\text { HS: } 1 . \text { Dividing high school } \\
\text { classes. 2. Develop thematic units } \\
\text { in Eng. using outside novels. } 3 \text {. } \\
\text { Adopt a new U.S. History text. } 4 \text {. } \\
\text { Switch to teaching keyboarding on } \\
\text { computers. 5. Plan an orientation } \\
\text { session with 9th grade in fall. }\end{array}$ & & \\
\hline \multicolumn{3}{|l|}{ SCHOOL \#12 TOTALS } \\
\hline 6 items & $0-0 \%$ & $0-0 \% /$ Total $-0 \%$ \\
\hline
\end{tabular}




\begin{tabular}{|c|c|c|}
\hline $\begin{array}{c}\text { STATEMENT(S) } \\
\text { FROM LONG-RANGE PLAN }\end{array}$ & $\begin{array}{c}\text { COMPARATIVE } \\
\text { STATEMENT(S) FROM JOB } \\
\text { DESCRIPTION }\end{array}$ & $\begin{array}{c}\text { COMPARATIVE } \\
\text { STATEMENT(S) FROM } \\
\text { EVALUATION } \\
\text { DOCUMENTS }\end{array}$ \\
\hline \multicolumn{3}{|l|}{ SCHOOL \#13 } \\
\hline $\begin{array}{l}\text { - While this plan is labeled } \\
\text { "Strategic Plan for 1994-1995" it } \\
\text { appears to be a report which deals } \\
\text { with key result areas such as } \\
\text { curriculum, accreditation, facilities, } \\
\text { staff, etc. but only alludes to the } \\
\text { need for plans and goals in certain } \\
\text { areas.(i.e. "Our facilities will not } \\
\text { adequately house any more growth } \\
\text { unless a major building plan is } \\
\text { considered." or the upper school's } \\
\text { curriculum is organized, but there } \\
\text { are weaknesses in the following } \\
\text { areas:") } \\
\text { This "plan" appears to be the } \\
\text { culmination of pre-planning } \\
\text { activities and needs to be } \\
\text { developed into a plan that can be } \\
\text { implemented. }\end{array}$ & $\begin{array}{l}\text { The principal's (administrator's) job } \\
\text { description does line up with some } \\
\text { of the general areas in the report such } \\
\text { as instructional leadership, } \\
\text { supervision, finances, etc. but not in } \\
\text { a way that can be measured by clear } \\
\text { goals. } \\
\text { - Two items of importance from the } \\
\text { job description are listed under } \\
\text { "Research". They are: To maintain a } \\
\text { valid five year plan for the school. } \\
\text { and To provide specific information } \\
\text { for long range planning. } \\
\text { This report does the latter but not the } \\
\text { former. }\end{array}$ & $\begin{array}{l}\text { The evaluation form deals } \\
\text { with general traits of the } \\
\text { administrator such as } \\
\text { initiative, analytical skills, } \\
\text { judgement, creativity, etc. }\end{array}$ \\
\hline \multicolumn{3}{|l|}{ SCHOOL \#13 TOTALS } \\
\hline SCHOOL \#14 & 0 items - $0 \%$ / 1 planning statement & 0 items $-0 \%$ / Total $-0 \%$ \\
\hline $\begin{array}{l}\text { - Facilities: Seven specific goals } \\
\text { including, upgrade computer } \\
\text { equipment Signage, beautification } \\
\text { project, additional classrooms, a } \\
\text { science and technology center, and } \\
\text { expansion of gymnasium locker } \\
\text { room complex. }\end{array}$ & $\begin{array}{l}\text { Job description is philosophical in } \\
\text { nature and doesn't yield specific } \\
\text { connections to the plan. }\end{array}$ & $\begin{array}{l}\text { - No evaluation document } \\
\text { available. }\end{array}$ \\
\hline $\begin{array}{l}\text { - Curriculum: Seven specific goals } \\
\text { including, a non-college } \\
\text { preparatory track, upgrade the } \\
\text { computer curriculum, upgrade } \\
\text { mathematics offerings, Spanish } \\
\text { instruction in the junior high } \\
\text { school, and eventually, in the } \\
\text { elementary school, addition of a } \\
\text { fine arts magnet program, explore } \\
\text { the possibility of introducing } \\
\text { advance placement courses in } \\
\text { Chemistry, Physics, and Anatomy } \\
\text { and Physiology. }\end{array}$ & & \\
\hline
\end{tabular}




\begin{tabular}{|c|c|c|}
\hline $\begin{array}{c}\text { STATEMENT(S) } \\
\text { FROM LONG-RANGE PLAN }\end{array}$ & $\begin{array}{c}\text { COMPARATIVE } \\
\text { STATEMENT(S) FROM JOB } \\
\text { DESCRIPTION }\end{array}$ & $\begin{array}{c}\text { COMPARATIVE } \\
\text { STATEMENT(S) FROM } \\
\text { EVALUATION } \\
\text { DOCUMENTS }\end{array}$ \\
\hline $\begin{array}{l}\text { Personnel: Eight specific goals } \\
\text { including, additional math } \\
\text { personnel, an assistant bookkeeper, } \\
\text { an athletic secretary, begin } \\
\text { planning, financially, for the } \\
\text { addition of an employee trained in } \\
\text { computer operations, increase in } \\
\text { special area teachers, summer } \\
\text { activities coordinator, reading } \\
\text { specialist. }\end{array}$ & & \\
\hline $\begin{array}{l}\text { - Student activities: Two specific } \\
\text { goals including, expansion of } \\
\text { athletics and expansion of } \\
\text { community service. }\end{array}$ & & \\
\hline $\begin{array}{l}\text { - Summer Programs: Two specific } \\
\text { goals including, a consideration of } \\
\text { a year round preschool program } \\
\text { and expanded summer recreational } \\
\text { programs. }\end{array}$ & & \\
\hline \multicolumn{3}{|l|}{ SCHOOL \#14 TOTALS } \\
\hline 5 items & 0 items $-0 \%$ & 0 items $-0 \%$ / Total $-0 \%$ \\
\hline \multicolumn{3}{|l|}{ SCHOOL \#15 } \\
\hline $\begin{array}{l}\text { Besides a very clear facility } \\
\text { development plan with drawings, } \\
\text { this plan consists of the following } \\
\text { "Strategic Goals": }\end{array}$ & $\begin{array}{l}\text { Shall submit plans annually for the } \\
\text { development of programs in } \\
\text { curriculum, building, equipment, and } \\
\text { staffing as part of the long range } \\
\text { strategy for the total development of } \\
\text { the school. }\end{array}$ & $\begin{array}{l}\text { Submits plans annually for } \\
\text { the development of } \\
\text { programs in curriculum, } \\
\text { building, equipment, and } \\
\text { staffing as part of the long } \\
\text { range strategy for the total } \\
\text { development of the school. }\end{array}$ \\
\hline $\begin{array}{l}\text { - To improve written curriculum } \\
\text { from general departmental } \\
\text { objectives to measurable objectives } \\
\text { in five subject areas(Bible, English, } \\
\text { math, social studies, science) for } \\
\text { each grade level over the next three } \\
\text { years. }\end{array}$ & $\begin{array}{l}\text { Shall submit plans annually for the } \\
\text { development of programs in } \\
\text { curriculum, building, equipment, and } \\
\text { staffing as part of the long range } \\
\text { strategy for the total development of } \\
\text { the school. }\end{array}$ & $\begin{array}{l}\text { Submits plans annually for } \\
\text { the development of } \\
\text { programs in curriculum, } \\
\text { building, equipment, and } \\
\text { staffing as part of the long } \\
\text { range strategy for the total } \\
\text { development of the school. }\end{array}$ \\
\hline $\begin{array}{l}\text { To develop an awareness of safety } \\
\text { issues and to eliminate potential } \\
\text { safety hazards in the areas of the } \\
\text { gym, the shop, the parking lot, and } \\
\text { classrooms. }\end{array}$ & $\begin{array}{l}\text { Shall submit plans annually for the } \\
\text { development of programs in } \\
\text { curriculum, building, equipment, and } \\
\text { staffing as part of the long range } \\
\text { strategy for the total development of } \\
\text { the school. }\end{array}$ & $\begin{array}{l}\text { Submits plans annually for } \\
\text { the development of } \\
\text { programs in curriculum, } \\
\text { building, equipment, and } \\
\text { staffing as part of the long } \\
\text { range strategy for the total } \\
\text { development of the school. }\end{array}$ \\
\hline
\end{tabular}




\begin{tabular}{|c|c|c|}
\hline $\begin{array}{c}\text { STATEMENT(S) } \\
\text { FROM LONG-RANGE PLAN }\end{array}$ & $\begin{array}{c}\text { COMPARATIVE } \\
\text { STATEMENT(S) FROM JOB } \\
\text { DESCRIPTION }\end{array}$ & $\begin{array}{c}\text { COMPARATIVE } \\
\text { STATEMENT(S) FROM } \\
\text { EVALUATION } \\
\text { DOCUMENTS } \\
\end{array}$ \\
\hline \multirow{2}{*}{$\begin{array}{l}\text { To increase family enrollment } \\
\text { through recruitment and retention } \\
\text { by } 2 \% \text { per year for the next three } \\
\text { years. }\end{array}$} & $\begin{array}{l}\text { Oversee the process of recruitment } \\
\text { and retention of students. }\end{array}$ & $\begin{array}{l}\text { Oversees the process of } \\
\text { recruitment and retention } \\
\text { of students. }\end{array}$ \\
\hline & $\begin{array}{l}\text { Work with the school board in } \\
\text { drafting an aggressive strategic long } \\
\text { range plan with objectives, goals, } \\
\text { methods, and a reasonable time line. } \\
\text { Develop and maintain reports on } \\
\text { progress toward goals. }\end{array}$ & $\begin{array}{l}\text { Works with the school } \\
\text { board in drafting an } \\
\text { aggressive strategic long } \\
\text { range plan with objectives, } \\
\text { goals, methods, and a } \\
\text { reasonable time line. } \\
\text { - Develop and maintain } \\
\text { reports on progress toward } \\
\text { goal }\end{array}$ \\
\hline \multicolumn{3}{|l|}{ SCHOOL \#15 TOTALS } \\
\hline 4 items & 4 items $-100 \%$ / 1 planning statement & $\begin{array}{l}4 \text { items - } 100 \% \text { / } 1 \text { planning } \\
\text { statement / Total - } 100 \%\end{array}$ \\
\hline \multicolumn{3}{|l|}{ SCHOOL \# 16} \\
\hline $\begin{array}{l}\text { Curricular: a list of eighteen items } \\
\text { to be addressed including } \\
\text { expanded course offerings, } \\
\text { refinement and extension of } \\
\text { present courses and certain results } \\
\text { related to achievement. }\end{array}$ & $\begin{array}{l}\text { Plan, implement, and coordinate the } \\
\text { development of comprehensive } \\
\text { educational, spiritual, and extra } \\
\text { curricular programs to meet the } \\
\text { needs of the students. } \\
\text { - Help develop curriculum goals for } \\
\text { the school and for each department. } \\
\text { - Assist in the improvement of the } \\
\text { instructional program and upgrading } \\
\text { of curriculum. }\end{array}$ & $\begin{array}{l}\text { - Participates with staff and } \\
\text { board in studying and } \\
\text { developing curriculum } \\
\text { improvement. }\end{array}$ \\
\hline $\begin{array}{l}\text { Personnel: a list of ten items to be } \\
\text { addressed including increased } \\
\text { compensation, expansion of staff, } \\
\text { and increased professionalism. }\end{array}$ & $\begin{array}{l}\text { Recruit and make recommendations } \\
\text { to the board in the selection of new } \\
\text { teachers and staff. } \\
\text { - Evaluate the performance of each } \\
\text { faculty person. } \\
\text { Encourage each teacher to grow } \\
\text { professionally. }\end{array}$ & $\begin{array}{l}\text { - Organizes a planned } \\
\text { program of staff evaluation } \\
\text { and improvement. } \\
\text { - } \text { Evaluates personnel and } \\
\text { programs effectively. } \\
\text { - } \text { Plans an organized } \\
\text { program for recruitment, } \\
\text { screening, and } \\
\text { recommending staff. }\end{array}$ \\
\hline $\begin{array}{l}\text { - Spiritual: a list of thirteen items to } \\
\text { be addressed including increased } \\
\text { prayer, increased outreach, core } \\
\text { curriculum in Bible, focus on } \\
\text { discipleship of students. }\end{array}$ & $\begin{array}{l}\text { Plan, implement, and coordinate the } \\
\text { development of comprehensive } \\
\text { educational, spiritual, and extra } \\
\text { curricular programs to meet the } \\
\text { needs of the students }\end{array}$ & $\begin{array}{l}\text { Is considered spiritual } \\
\text { leader of the school. }\end{array}$ \\
\hline
\end{tabular}




\begin{tabular}{|c|c|c|}
\hline $\begin{array}{c}\text { STATEMENT(S) } \\
\text { FROM LONG-RANGE PLAN }\end{array}$ & $\begin{array}{c}\text { COMPARATIVE } \\
\text { STATEMENT(S) FROM JOB } \\
\text { DESCRIPTION }\end{array}$ & \begin{tabular}{c|} 
COMPARATIVE \\
STATEMENT(S) FROM \\
EVALUATION \\
DOCUMENTS \\
\end{tabular} \\
\hline $\begin{array}{l}\text { Extra-Curricular: a list of twelve } \\
\text { items to be addressed including } \\
\text { expanded clubs, sports, academic } \\
\text { competitions and honor societies. }\end{array}$ & $\begin{array}{l}\text { Plan, implement, and coordinate the } \\
\text { development of comprehensive } \\
\text { educational, spiritual, and extra } \\
\text { curricular programs to meet the } \\
\text { needs of the students }\end{array}$ & \\
\hline $\begin{array}{l}\text { - Facilities: a list of sixteen items to } \\
\text { be addressed including expanded } \\
\text { classrooms, expanded athletic } \\
\text { facilities, improvement of existing } \\
\text { facility with A/C and acoustic } \\
\text { considerations. }\end{array}$ & $\begin{array}{l}\text { - Recommend building improvements } \\
\text { and needs to the board. }\end{array}$ & \\
\hline $\begin{array}{l}\text { Miscellaneous: Two items to be } \\
\text { addressed; tuition assistance and } \\
\text { added computer equipment. }\end{array}$ & & \\
\hline \multicolumn{3}{|l|}{ SCHOOL \#16 TOTALS } \\
\hline 6 items & 5 items $-83.333 \%$ & $\begin{array}{l}3 \text { items }-50 \% / \text { Total } \\
66.667 \%\end{array}$ \\
\hline \multicolumn{3}{|l|}{ SCHOOL \#17 } \\
\hline $\begin{array}{l}\text { - Capacity: (general target for } \\
\text { number of students served) } 3 \text { years } \\
\text { (96-97) - 600, } 5 \text { years (98-99) - } \\
\text { 700, a working comprehensive } \\
\text { long range recruitment plan. }\end{array}$ & & $\begin{array}{l}\text { - No evaluation document } \\
\text { available }\end{array}$ \\
\hline $\begin{array}{l}\text { Program: (new programs, } \\
\text { activities) develop "applied } \\
\text { technology", computer lab, drama, } \\
\text { art, foreign language in middle } \\
\text { school, resource room, greater } \\
\text { mission/service, night school for } \\
\text { computers. }\end{array}$ & - Coordination of the total program & \\
\hline $\begin{array}{l}\text { PR, Image, Marketing: (building } \\
\text { awareness, providing information) } \\
\text { communicate with churches, } \\
\text { creation of "speakers bureau", } \\
\text { membership in service clubs, a } \\
\text { working comprehensive long range } \\
\text { public relations plan. }\end{array}$ & $\begin{array}{l}\text { The Headmaster shall work closely } \\
\text { with the development dept. in } \\
\text { planning and carrying out an } \\
\text { effective program of interpreting the } \\
\text { school to the public. }\end{array}$ & \\
\hline
\end{tabular}




\begin{tabular}{|c|c|c|}
\hline $\begin{array}{c}\text { STATEMENT(S) } \\
\text { FROM LONG-RANGE PLAN }\end{array}$ & $\begin{array}{c}\text { COMPARATIVE } \\
\text { STATEMENT(S) FROM JOB } \\
\text { DESCRIPTION }\end{array}$ & $\begin{array}{c}\text { COMPARATIVE } \\
\text { STATEMENT(S) FROM } \\
\text { EVALUATION } \\
\text { DOCUMENTS }\end{array}$ \\
\hline $\begin{array}{l}\text { Fund-raising, Development: (how } \\
\text { much money we need to raise to } \\
\text { sustain the organization) annual } \\
\text { fund }=10-12 \% \text { of annual budget, } \\
30-50 \text { fully funded scholarships, } \\
\text { raise } \$ 2,000,000 \text { over } 3 \text { years } \\
\text { through the } 1994 \text { capital campaign, } \\
\text { market competitive salary } \\
\text { structure, a working } \\
\text { comprehensive long range } \\
\text { development plan. }\end{array}$ & & \\
\hline $\begin{array}{l}\text { Board Strengthening: (what we } \\
\text { need to do to bring board into } \\
\text { alignment with needs) greater } \\
\text { focus on fund-raising, working } \\
\text { committees, all board will have } \\
\text { attended Templeton institute, } \\
\text { create advisory board. }\end{array}$ & & \\
\hline \multirow[t]{2}{*}{$\begin{array}{l}\text { Organization, Administration: } \\
\text { (what we need to fix or change } \\
\text { internally) director of } \\
\text { development/recruitment, } \\
\text { transportation coordinator, update } \\
\text { constitution, develop policy } \\
\text { manual, begin budget process in } \\
\text { Nov. }\end{array}$} & & \\
\hline & $\begin{array}{l}\text { The headmaster shall submit plans } \\
\text { annually for developmental programs } \\
\text { in curriculum, staff, buildings and } \\
\text { equipment and publications as part } \\
\text { of a long range plan for the total } \\
\text { development of the school. He/she } \\
\text { shall initiate new programs as needed } \\
\text { and approved by the board. }\end{array}$ & \\
\hline \multicolumn{3}{|l|}{ SCHOOL \#17 TOTALS } \\
\hline 6 items & $\begin{array}{l}2 \text { items - } 33.333 \% \text { / } 1 \text { planning } \\
\text { statement }\end{array}$ & $\begin{array}{l}0 \text { items } 0 \% \text { / Total - } \\
16.667 \%\end{array}$ \\
\hline \multicolumn{3}{|l|}{ SCHOOL \#18 } \\
\hline $\begin{array}{l}\text { Financial: stabilize or reduce } \\
\text { tuition, increase scholarships for } \\
\text { low income families, increase } \\
\text { teachers' salaries over five years, } \\
\text { more realistic budgeting, set aside } \\
\$ 10,000 \text { per year as surplus. }\end{array}$ & & $\begin{array}{l}\text { - No evaluation document } \\
\text { available. }\end{array}$ \\
\hline
\end{tabular}




\begin{tabular}{|c|c|c|}
\hline $\begin{array}{c}\text { STATEMENT(S) } \\
\text { FROM LONG-RANGE PLAN }\end{array}$ & $\begin{array}{c}\text { COMPARATIVE } \\
\text { STATEMENT(S) FROM JOB } \\
\text { DESCRIPTION }\end{array}$ & $\begin{array}{c}\text { COMPARATIVE } \\
\text { STATEMENT(S) FROM } \\
\text { EVALUATION } \\
\text { DOCUMENTS } \\
\end{array}$ \\
\hline $\begin{array}{l}\text { - Program: develop a middle school } \\
\text { program. }\end{array}$ & $\begin{array}{l}\text { - *The Chief Administrator shall work } \\
\text { with the Assistant Administrator in } \\
\text { the evaluation, selection, integration } \\
\text { and formation of the school's } \\
\text { curriculum... } \\
\text { * These two items are connected in the } \\
\text { most general sense only. }\end{array}$ & \\
\hline $\begin{array}{l}\text { - Publicity: develop better means of } \\
\text { communicating with parents, } \\
\text { Improve community image with } \\
\text { signs, banners and property maint., } \\
\text { cultivate support of local churches, } \\
\text { create parenting seminars and } \\
\text { family activities. }\end{array}$ & & \\
\hline $\begin{array}{l}\text { Facilities: nine specific goals listed } \\
\text { including completion of a new } \\
\text { building, purchase of property, } \\
\text { removal of portable buildings and } \\
\text { master facility plan. }\end{array}$ & & \\
\hline \multicolumn{3}{|l|}{ SCHOOL \#18 TOTALS } \\
\hline 4 items & 1 item $25 \%$ & 0 items $0 \%$ / Total $-12.5 \%$ \\
\hline
\end{tabular}




\begin{tabular}{|c|c|c|}
\hline $\begin{array}{c}\text { STATEMENT(S) } \\
\text { FROM LONG-RANGE PLAN }\end{array}$ & $\begin{array}{c}\text { COMPARATIVE } \\
\text { STATEMENT(S) FROM JOB } \\
\text { DESCRIPTION }\end{array}$ & $\begin{array}{c}\text { COMPARATIVE } \\
\text { STATEMENT(S) FROM } \\
\text { EVALUATION } \\
\text { DOCUMENTS } \\
\end{array}$ \\
\hline \multicolumn{3}{|l|}{ SCHOOL \#19 } \\
\hline $\begin{array}{l}\text { - Excellence in Education: four } \\
\text { categories of specific goals } \\
\text { including, using the accreditation } \\
\text { process as a base for continual } \\
\text { school improvement, } \\
\text { computerization of } 5 \text { school } \\
\text { departments, improving the } \\
\text { quality and qualifications of the } \\
\text { staff, improving and expanding the } \\
\text { morals/values aspects of } \\
\text { curriculum, staff and activities. }\end{array}$ & $\begin{array}{l}\text { - Plans and coordinates the total } \\
\text { curriculum of the school through the } \\
\text { Education Committee. } \\
\text { - Promotes staff development through } \\
\text { in-service training, conferences and } \\
\text { evaluations. }\end{array}$ & $\begin{array}{l}\text { - No evaluation document } \\
\text { available }\end{array}$ \\
\hline \multicolumn{3}{|l|}{$\begin{array}{l}\text { Development \& Capital Funding: } \\
\text { two categories of specific goals } \\
\text { including, cultivating sources of } \\
\text { funding both inside and outside the } \\
\text { school and the creation of both a } \\
\text { development office and a } \\
\text { development committee. }\end{array}$} \\
\hline \multicolumn{3}{|l|}{$\begin{array}{l}\text { - Facilities \& Location: Two } \\
\text { categories of specific goals } \\
\text { including, expansion of present } \\
\text { facilities, search for a new location } \\
\text { for expansion, consolidation and } \\
\text { greater accessibility, } \\
\text { accommodation of expanding } \\
\text { enrollment and development of } \\
\text { extra-curriculars. }\end{array}$} \\
\hline $\begin{array}{l}\text { - Positioning: six categories of } \\
\text { specific goals including, improved } \\
\text { communication and public } \\
\text { relations, ethnic outreach, funding } \\
\text { of tuition assistance, targeting of } \\
\text { community growth areas. }\end{array}$ & $\begin{array}{l}\text { - Conducts an active program of } \\
\text { student recruitment in the greater } \\
\text { (name of city) area. } \\
\text { - Develops an effective and efficient } \\
\text { public relations program, including } \\
\text { the preparation of brochures and } \\
\text { "fact sheets" that portrays the needs, } \\
\text { desires and successes of (name of } \\
\text { school) to the constituency and } \\
\text { general public. }\end{array}$ & \\
\hline \multicolumn{3}{|l|}{ SCHOOL \#19 TOTALS } \\
\hline 4 items & 2 items $-50 \%$ & 0 items $0 \%$ / Total $12.5 \%$ \\
\hline
\end{tabular}




\begin{tabular}{|c|c|c|}
\hline $\begin{array}{c}\text { STATEMENT(S) } \\
\text { FROM LONG-RANGE PLAN }\end{array}$ & $\begin{array}{c}\text { COMPARATIVE } \\
\text { STATEMENT(S) FROM JOB } \\
\text { DESCRIPTION }\end{array}$ & $\begin{array}{c}\text { COMPARATIVE } \\
\text { STATEMENT(S) FROM } \\
\text { EVALUATION } \\
\text { DOCUMENTS } \\
\end{array}$ \\
\hline \multicolumn{3}{|l|}{ SCHOOL \#20 } \\
\hline $\begin{array}{l}\text { Faculty: goals for the expansion of } \\
\text { the faculty are listed in the areas of } \\
\text { band, French, computer, phys. ed., } \\
\text { art, and coaching. }\end{array}$ & $\begin{array}{l}\text { - Selection of faculty and staff. } \\
\text { Supervision of faculty and staff and } \\
\text { academic programs. }\end{array}$ & $\begin{array}{l}\text { - No evaluation document } \\
\text { available }\end{array}$ \\
\hline $\begin{array}{l}\text { Administration: goals for the } \\
\text { addition of administrators in grades } \\
\text { K-6 and 7-12, guidance, } \\
\text { admissions, development and } \\
\text { public relations. }\end{array}$ & - Selection of faculty and staff. & \\
\hline $\begin{array}{l}\text { - Chain of Command: allusion is } \\
\text { made to chain of command issues } \\
\text { and a flow chart is presented wit } \\
\text { recommended positions on it. }\end{array}$ & & \\
\hline $\begin{array}{l}\text { Facilities: thirteen specific goals } \\
\text { are listed all having to do with } \\
\text { library/ media expansion and } \\
\text { computerization. }\end{array}$ & & \\
\hline \multirow[t]{2}{*}{$\begin{array}{l}\text { Ideas for Encouragement and } \\
\text { Growth in the Vision of (name of } \\
\text { school): seven specific goals listed } \\
\text { including, time for reflection and } \\
\text { spiritual growth, better orientation } \\
\text { and training of staff as to } \\
\text { mission/vision of school, better } \\
\text { communication and training for } \\
\text { parents, reiteration of standards } \\
\text { and rationale for them. }\end{array}$} & $\begin{array}{l}\text { - Insuring(sic) the proper Christian } \\
\text { environment in general. }\end{array}$ & \\
\hline & $\begin{array}{l}\text { Planning the school's future through } \\
\text { short term and long range planning. }\end{array}$ & \\
\hline \multicolumn{3}{|l|}{ SCHOOL \#20 TOTALS } \\
\hline 5 items & 3 items $-60 \%$ / 1 planning statement & 0 items $-0 \%$ / Total $-30 \%$ \\
\hline \multicolumn{3}{|l|}{ SCHOOL \#21 } \\
\hline $\begin{array}{l}\text { Expand and improve the (school } \\
\text { name) office facilities and staff: } \\
\text { eight action steps listed. }\end{array}$ & & $\begin{array}{l}\text { - No evaluation document } \\
\text { available. }\end{array}$ \\
\hline $\begin{array}{l}\text { Move school administrator from } \\
\text { school staff to church staff: four } \\
\text { action steps listed. }\end{array}$ & & \\
\hline
\end{tabular}




\begin{tabular}{|c|c|c|}
\hline $\begin{array}{c}\text { STATEMENT(S) } \\
\text { FROM LONG-RANGE PLAN }\end{array}$ & $\begin{array}{c}\text { COMPARATIVE } \\
\text { STATEMENT(S) FROM JOB } \\
\text { DESCRIPTION }\end{array}$ & $\begin{array}{c}\text { COMPARATIVE } \\
\text { STATEMENT(S) FROM } \\
\text { EVALUATION } \\
\text { DOCUMENTS } \\
\end{array}$ \\
\hline $\begin{array}{l}\text { Investigate and plan for class } \\
\text { placement without new building } \\
\text { space for the next five years: four } \\
\text { action steps listed. }\end{array}$ & & \\
\hline $\begin{array}{l}\text { - Investigate and plan for use of } \\
\text { library funds, purchase of library } \\
\text { books and placement of library in } \\
\text { light of present capacity: four } \\
\text { action steps listed. }\end{array}$ & & \\
\hline $\begin{array}{l}\text { - Implement a learning disabilities } \\
\text { program at (name of school): six } \\
\text { action steps listed. }\end{array}$ & $\begin{array}{l}\text { - To develop and to maintain a school } \\
\text { which is academically sound for the } \\
\text { student body which it serves. }\end{array}$ & \\
\hline $\begin{array}{l}\text { - Upgrade the playgrounds: three } \\
\text { action steps listed. }\end{array}$ & $\begin{array}{l}\text { - To see that the school is well } \\
\text { equipped and well supplied to } \\
\text { provide quality education. } \\
\text { - To help with fund raising for the } \\
\text { annual budget and for capital } \\
\text { improvements. }\end{array}$ & \\
\hline \multicolumn{3}{|l|}{$\begin{array}{l}\text { Provide a support system for } \\
\text { Christian families who choose to } \\
\text { home school: four action steps } \\
\text { listed. }\end{array}$} \\
\hline & $\begin{array}{l}\text { - To maintain a valid five year plan for } \\
\text { the development of the school. } \\
\text { - To provide specific information for } \\
\text { long range planning. }\end{array}$ & \\
\hline \multicolumn{3}{|l|}{ SCHOOL \#21 TOTALS } \\
\hline 7 items & $\begin{array}{l}2 \text { items - } 28.571 \% \text { / } 1 \text { planning } \\
\text { statement }\end{array}$ & $\begin{array}{l}0 \text { items }-0 \% \text { / Total } \\
14.286 \%\end{array}$ \\
\hline \multicolumn{3}{|l|}{ SCHOOL \#22 } \\
\hline $\begin{array}{l}\text { Evangelism \& Outreach: seven } \\
\text { specific goals including increased } \\
\text { student response to spiritual things, } \\
\text { increased enrollment, particularly } \\
\text { of minorities, better public } \\
\text { relations and community service. }\end{array}$ & & \\
\hline
\end{tabular}




\begin{tabular}{|c|c|c|}
\hline $\begin{array}{c}\text { STATEMENT(S) } \\
\text { FROM LONG-RANGE PLAN }\end{array}$ & $\begin{array}{c}\text { COMPARATIVE } \\
\text { STATEMENT(S) FROM JOB } \\
\text { DESCRIPTION }\end{array}$ & $\begin{array}{c}\text { COMPARATIVE } \\
\text { STATEMENT(S) FROM } \\
\text { EVALUATION } \\
\text { DOCUMENTS } \\
\end{array}$ \\
\hline $\begin{array}{l}\text { Missions: five specific goals } \\
\text { including, involvement in ACSI } \\
\text { Missions Day, tuition discount for } \\
\text { pastors, adopt a missionary family, } \\
\text { offerings and sponsorship of } \\
\text { foreign students. }\end{array}$ & & \\
\hline $\begin{array}{l}\text { Ministry: seven specific goals } \\
\text { including, school workdays, } \\
\text { ministry opportunities for families, } \\
\text { update policy manual, expand } \\
\text { cross-age tutoring, set up evening } \\
\text { computer classes. }\end{array}$ & $\begin{array}{l}\text { - Coordinate special instructional } \\
\text { programs. }\end{array}$ & \\
\hline $\begin{array}{l}\text { - Training \& Spiritual Development: } \\
\text { four specific goals including, } \\
\text { increased staff in service training, } \\
\text { Bible courses, develop a Parents as } \\
\text { Disciples conference, Increase } \\
\text { student participation in Bible } \\
\text { learning activities. }\end{array}$ & & $\begin{array}{l}\text { Work with staff } \\
\text { development person, } \\
\text { faculty, and specialists in } \\
\text { developing an in service } \\
\text { program, relative to the } \\
\text { needs of the school. }\end{array}$ \\
\hline $\begin{array}{l}\text { Stewardship: five specific goals } \\
\text { including, increase in teacher } \\
\text { salaries, purchase of two vehicles, } \\
\text { increased financial assistance to } \\
\text { families, improve annual support } \\
\text { banquet, increase annual fund } \\
\text { giving. }\end{array}$ & $\begin{array}{l}\text { - Help the development department in } \\
\text { all its activities including the "Faith } \\
\text { Promise Dinner", fund raising, and } \\
\text { visiting other schools. } \\
\text { - Establish a broad financial base for } \\
\text { the school, through various means. }\end{array}$ & \\
\hline $\begin{array}{l}\text { Prayer: four specific goals } \\
\text { including, two day staff retreat, } \\
\text { develop an active school prayer } \\
\text { group, communicate prayer needs } \\
\text { regularly to staff and students. }\end{array}$ & & \\
\hline $\begin{array}{l}\text { Worship and Music: five specific } \\
\text { goals including, developing several } \\
\text { chapels on the theme of worship, } \\
\text { spiritual emphasis week (grades 6- } \\
\text { 12), develop a high school vocal } \\
\text { ensemble and an orchestra. }\end{array}$ & & \\
\hline $\begin{array}{l}\text { - Academy Staff: five specific goals } \\
\text { including, expansion of staff for } \\
\text { growth and in special areas. }\end{array}$ & $\begin{array}{l}\text { - To interview prospective teachers for } \\
\text { employment. }\end{array}$ & \\
\hline
\end{tabular}




\begin{tabular}{|c|c|c|}
\hline $\begin{array}{c}\text { STATEMENT(S) } \\
\text { FROM LONG-RANGE PLAN }\end{array}$ & $\begin{array}{c}\text { COMPARATIVE } \\
\text { STATEMENT(S) FROM JOB } \\
\text { DESCRIPTION }\end{array}$ & $\begin{array}{c}\text { COMPARATIVE } \\
\text { STATEMENT(S) FROM } \\
\text { EVALUATION } \\
\text { DOCUMENTS } \\
\end{array}$ \\
\hline $\begin{array}{l}\text { - Curriculum and Instruction: } \\
\text { fourteen specific goals including, } \\
\text { expansion of course offerings, } \\
\text { acquisition of more materials and } \\
\text { equipment, successful } \\
\text { reaccreditation, more hands on } \\
\text { activities inside and outside of the } \\
\text { classroom, more students } \\
\text { participating in band. }\end{array}$ & $\begin{array}{l}\text { - Work with the faculty to develop } \\
\text { student activities. } \\
\text { - Oversee the development of goals } \\
\text { and objectives in the various } \\
\text { academic areas... } \\
\text { - To provide leadership in } \\
\text { curriculum... }\end{array}$ & $\begin{array}{l}\text { - Assists staff members in } \\
\text { evaluating their methods } \\
\text { and instructional materials. } \\
\text { - Assists the staff to develop } \\
\text { meaningful goals, } \\
\text { objectives, and strategies. }\end{array}$ \\
\hline \multicolumn{3}{|l|}{ SCHOOL \#22 TOTALS } \\
\hline \multicolumn{3}{|l|}{ SCHOOL \#23 } \\
\hline $\begin{array}{l}\text { Enrollment: four specific numerical } \\
\text { goals over four years. }\end{array}$ & & $\begin{array}{l}\text { - No evaluation form } \\
\text { available. }\end{array}$ \\
\hline $\begin{array}{l}\text { - Budget: four specific monetary } \\
\text { goals over four years. }\end{array}$ & $\begin{array}{l}\text { - Install plan for annual budget. } \\
\text { - Work with office manager and } \\
\text { administrators to prepare budget. }\end{array}$ & \\
\hline \multicolumn{3}{|l|}{$\begin{array}{l}\text { Program Added: five specific } \\
\text { courses to be added over four } \\
\text { years. }\end{array}$} \\
\hline $\begin{array}{l}\text { - Staff Personnel: two new teaching } \\
\text { positions over four years. }\end{array}$ & $\begin{array}{l}\text { - Contact, interview and hire staff } \\
\text { members. }\end{array}$ & \\
\hline \multicolumn{3}{|l|}{$\begin{array}{l}\text { Rent: four specific rent projection } \\
\text { figures over four years. }\end{array}$} \\
\hline \multicolumn{3}{|l|}{$\begin{array}{l}\text { - Salaries: four specific salary targets } \\
\text { over five years. }\end{array}$} \\
\hline $\begin{array}{l}\text { - Staff Retreat: four locations listed } \\
\text { over four years. }\end{array}$ & $\begin{array}{l}\text { - Plan all-staff meetings and events } \\
\text { such as: a. staff retreat in August. }\end{array}$ & \\
\hline \multicolumn{3}{|l|}{$\begin{array}{l}\text { In-Service: This item is unclear. } \\
\text { Three key words are listed over the } \\
\text { first three years of the plan. }\end{array}$} \\
\hline $\begin{array}{l}\text { Staff/Student Trips: four locations } \\
\text { (three foreign) listed over four } \\
\text { years. }\end{array}$ & $\begin{array}{l}\text { Help plan student trips such as } \\
\text { Washington DC, Disneyland, senior } \\
\text { trip, etc. }\end{array}$ & \\
\hline $\begin{array}{l}\text { Facility: four specific goals listed } \\
\text { including, building fund, staff } \\
\text { housing, storage, and land } \\
\text { purchase. }\end{array}$ & - Secure adequate facilities. & \\
\hline
\end{tabular}




\begin{tabular}{|c|c|c|}
\hline $\begin{array}{c}\text { STATEMENT(S) } \\
\text { FROM LONG-RANGE PLAN }\end{array}$ & $\begin{array}{c}\text { COMPARATIVE } \\
\text { STATEMENT(S) FROM JOB } \\
\text { DESCRIPTION }\end{array}$ & $\begin{array}{c}\text { COMPARATIVE } \\
\text { STATEMENT(S) FROM } \\
\text { EVALUATION } \\
\text { DOCUMENTS } \\
\end{array}$ \\
\hline $\begin{array}{l}\text { Ministries: Three outreach groups } \\
\text { listed (one twice) relative to four } \\
\text { years. }\end{array}$ & & \\
\hline \multicolumn{3}{|l|}{$\begin{array}{l}\text { Equipment: seven equipment } \\
\text { acquisitions listed over four years. } \\
\text { (one is "new gym"0 }\end{array}$} \\
\hline & $\begin{array}{l}\text { Establish 5-year and 10-year long } \\
\text { range goals. }\end{array}$ & \\
\hline \multicolumn{3}{|l|}{ SCHOOL \#23 } \\
\hline 12 items & $\begin{array}{l}5 \text { items }-41.667 \% \text { / } 1 \text { planning } \\
\text { statement }\end{array}$ & $\begin{array}{l}0 \text { items - 0\% / Total - } \\
20.833 \%\end{array}$ \\
\hline \multicolumn{3}{|l|}{ SCHOOL \#24 } \\
\hline $\begin{array}{l}\text { Academic Curriculum and College } \\
\text { Preparation: To provide students a } \\
\text { Biblically-integrated curriculum } \\
\text { that challenges, informs and } \\
\text { encourages everyone to meet their } \\
\text { academic potential. To prepare } \\
\text { students to gain admission to the } \\
\text { college or university of their } \\
\text { choice. nineteen action points } \\
\text { listed including, curriculum } \\
\text { evaluation, critical thinking, } \\
\text { meaningful homework, oral } \\
\text { expression, student progress, AP } \\
\text { scores, SAT scores, academic } \\
\text { incentive plan, research year-round } \\
\text { school, expand math, integration of } \\
\text { curriculum, computer skills, better } \\
\text { teaching methods, better discipline, } \\
\text { college admission process, } \\
\text { effectiveness review process, } \\
\text { support system for academically } \\
\text { challenged students. }\end{array}$ & $\begin{array}{l}\text { Besides statements about general } \\
\text { oversight of the school no } \\
\text { comparative statements could be } \\
\text { found in the job description. }\end{array}$ & $\begin{array}{l}\text { The evaluation of the } \\
\text { Headmaster is outlined in } \\
\text { his contract as occurring } \\
\text { annually and being based } \\
\text { on the duties set out in the } \\
\text { job description. }\end{array}$ \\
\hline
\end{tabular}




\begin{tabular}{|c|c|c|}
\hline $\begin{array}{c}\text { STATEMENT(S) } \\
\text { FROM LONG-RANGE PLAN }\end{array}$ & $\begin{array}{c}\text { COMPARATIVE } \\
\text { STATEMENT(S) FROM JOB } \\
\text { DESCRIPTION }\end{array}$ & $\begin{array}{c}\text { COMPARATIVE } \\
\text { STATEMENT(S) FROM } \\
\text { EVALUATION } \\
\text { DOCUMENTS } \\
\end{array}$ \\
\hline $\begin{array}{l}\text { Spiritual, Religious and Social } \\
\text { Education: To challenge students } \\
\text { to grow in their relationship to } \\
\text { Christ. To relate Biblically to all } \\
\text { members of the (school name) } \\
\text { family. To prepare students for } \\
\text { lives of leadership, citizenship and } \\
\text { service. six action points listed } \\
\text { including, comprehensive Bible } \\
\text { curriculum, improve faculty, } \\
\text { discipleship program, Christian } \\
\text { world view integrated into } \\
\text { curriculum. }\end{array}$ & & \\
\hline $\begin{array}{l}\text { - Co-curricular Activities: To } \\
\text { encourage students to participate in } \\
\text { a variety of co-curricular activities } \\
\text { which allow students to develop } \\
\text { their talents and gifts. five action } \\
\text { points listed including, balanced } \\
\text { recognition for all co-curricular } \\
\text { activities, better organization of } \\
\text { student activities, establish student } \\
\text { leadership class. }\end{array}$ & & \\
\hline $\begin{array}{l}\text { - Faculty: To recruit and retain a } \\
\text { dedicated, knowledgeable, and } \\
\text { spiritually mature faculty who can } \\
\text { communicate with and inspire } \\
\text { students. three action points listed } \\
\text { including, expand professional } \\
\text { development programs, continue } \\
\text { development of Faculty Career } \\
\text { program, national recruitment.. }\end{array}$ & & \\
\hline $\begin{array}{l}\text { Development - Funds - Facilities: } \\
\text { To operate the school on a sound } \\
\text { Biblical and financial basis at the } \\
\text { highest level of efficiency } \\
\text { consistent with the school's } \\
\text { programs and goals. two action } \\
\text { points listed, implement major gifts } \\
\text { program and prepare a complete } \\
\text { plan for facility expansion. }\end{array}$ & & \\
\hline \multicolumn{3}{|l|}{ SCHOOL \#24 } \\
\hline 5 items & 0 items - $0 \%$ & 0 items $-0 \%$ / Total $-0 \%$ \\
\hline
\end{tabular}




\begin{tabular}{|c|c|c|}
\hline $\begin{array}{c}\text { STATEMENT(S) } \\
\text { FROM LONG-RANGE PLAN }\end{array}$ & $\begin{array}{c}\text { COMPARATIVE } \\
\text { STATEMENT(S) FROM JOB } \\
\text { DESCRIPTION }\end{array}$ & $\begin{array}{c}\text { COMPARATIVE } \\
\text { STATEMENT(S) FROM } \\
\text { EVALUATION } \\
\text { DOCUMENTS } \\
\end{array}$ \\
\hline \multicolumn{3}{|l|}{ SCHOOL \#25 } \\
\hline $\begin{array}{l}\text { Educational Plan:(expectations of } \\
\text { graduate) eighteen specific goals } \\
\text { including, ongoing staff training,, } \\
\text { revise entrance testing, revise } \\
\text { course outline for T.A.'s, find } \\
\text { outside resources for curric. dev. } \\
\text { and grant writing, conduct a needs } \\
\text { assessment, establish an annual } \\
\text { graduate survey, develop task force } \\
\text { for exceptional students, develop } \\
\text { middle school model for } \\
\text { instruction, evaluate MS co- } \\
\text { curriculars, develop elem. fine arts, } \\
\text { develop philosophy of co- } \\
\text { curriculars, develop a "heart for } \\
\text { missions" program, enhance } \\
\text { foreign language programs, } \\
\text { develop scope and sequence for } \\
\text { tech. ed., integrate state } \\
\text { curriculum, more electives. }\end{array}$ & $\begin{array}{l}\text { - Supervises the implementation and } \\
\text { evaluation of adopted curricula and } \\
\text { text books, and recommends to the } \\
\text { Education Committee when major } \\
\text { curriculum changes are appropriate. } \\
\text { - Oversees the development and } \\
\text { utilization of scope and sequence of } \\
\text { each subject area through each } \\
\text { division. }\end{array}$ & $\begin{array}{l}\text { Implements and evaluates } \\
\text { adopted curricula and } \\
\text { recommends major } \\
\text { curriculum changes when } \\
\text { appropriate. }\end{array}$ \\
\hline $\begin{array}{l}\text { Personnel Plan: five specific goals } \\
\text { including, assign MS } \\
\text { administrator, limit teaching } \\
\text { assignments, provide ongoing } \\
\text { training for teachers, establish } \\
\text { reading requirements for staff, } \\
\text { clarify staffing based on } \\
\text { enrollment, clarify teacher } \\
\text { qualifications. }\end{array}$ & $\begin{array}{l}\text { Recommends to the board } \\
\text { concerning the creation and } \\
\text { elimination of staff positions. } \\
\text { - Ensures orientation of employees } \\
\text { with respect to their duties and in- } \\
\text { service development requirements. }\end{array}$ & $\begin{array}{l}\text { Recommends to the board } \\
\text { concerning the creation } \\
\text { and elimination of staff } \\
\text { positions. }\end{array}$ \\
\hline $\begin{array}{l}\text { Facilities Plan: five specific goals } \\
\text { with action points including, } \\
\text { maintaining buildings and grounds } \\
\text { with the appearance of newness } \\
\text { over five years, to provide a } \\
\text { dependable, safe, cost efficient } \\
\text { transportation system, develop an } \\
\text { efficient purchasing and inventory } \\
\text { system, develop property } \\
\text { acquisition plan, improve } \\
\text { teacher/parent group. }\end{array}$ & $\begin{array}{l}\text { Directs the routine maintenance and } \\
\text { operation of the plant. } \\
\text { - Proposes recommendations to the } \\
\text { board with respect to the necessity of } \\
\text { major repairs, improvements, or new } \\
\text { facilities. }\end{array}$ & $\begin{array}{l}\text { Directs the routine } \\
\text { maintenance and operation } \\
\text { of the plant. } \\
\text { - Recommends to the board } \\
\text { with respect to major } \\
\text { repairs, improvements, or } \\
\text { new facilities needed. }\end{array}$ \\
\hline
\end{tabular}




\begin{tabular}{|c|c|c|}
\hline $\begin{array}{c}\text { STATEMENT(S) } \\
\text { FROM LONG-RANGE PLAN }\end{array}$ & $\begin{array}{c}\text { COMPARATIVE } \\
\text { STATEMENT(S) FROM JOB } \\
\text { DESCRIPTION }\end{array}$ & $\begin{array}{c}\text { COMPARATIVE } \\
\text { STATEMENT(S) FROM } \\
\text { EVALUATION } \\
\text { DOCUMENTS } \\
\end{array}$ \\
\hline $\begin{array}{l}\text { Marketing (admissions } \\
\text { recruitment) no specific goals in } \\
\text { this area. Several questions to be } \\
\text { answered in the areas of } \\
\text { admissions, image, } \\
\text { communications strategies and } \\
\text { vehicles, church relationships, } \\
\text { students as recruiters. }\end{array}$ & $\begin{array}{l}\text { - Communicates with the community } \\
\text { at large and its institutions as needed. }\end{array}$ & $\begin{array}{l}\text { - Communicates with the } \\
\text { community at large and its } \\
\text { institutions as needed. }\end{array}$ \\
\hline $\begin{array}{l}\text { - Fund Development: two specific } \\
\text { goals train appropriate personnel in } \\
\text { grant writing and submit proposals } \\
\text { for grants. }\end{array}$ & & \\
\hline $\begin{array}{l}\text { Financial Plan: :no specific goals } \\
\text { in this area. Several discussion } \\
\text { points in the areas of salaries, } \\
\text { tuition, endowment, capital budget, } \\
\text { financial reserves. }\end{array}$ & & \\
\hline $\begin{array}{l}\text { Board Development: seven specific } \\
\text { goals including, annual board } \\
\text { member evaluation, board } \\
\text { recruitment system, board } \\
\text { orientation system, board member } \\
\text { education, establish an ongoing } \\
\text { master ministry planning process, } \\
\text { maintain regular, open and clear } \\
\text { communication with all } \\
\text { constituents, better support and } \\
\text { evaluation of superintendent. }\end{array}$ & & \\
\hline \multicolumn{3}{|l|}{ SCHOOL \#25 TOTALS } \\
\hline 7 items & 4 items $-57.143 \%$ & $\begin{array}{l}4 \text { items } 57.143 \% \text { / Total - } \\
57.143 \%\end{array}$ \\
\hline \multicolumn{3}{|l|}{ SCHOOL \#26 } \\
\hline $\begin{array}{l}\text { - Spiritual Development: seven } \\
\text { specific recommendations } \\
\text { including, effort to integrate, } \\
\text { improvement of teacher prayer } \\
\text { worship time, general improvement } \\
\text { of prayer, revision of Bible } \\
\text { curriculum, small group Bible } \\
\text { studies teachers/students. }\end{array}$ & $\begin{array}{l}\text { Provide leadership in the } \\
\text { development, revision, and } \\
\text { coordination of the school } \\
\text { curriculum }\end{array}$ & $\begin{array}{l}\text { - Is considered a spiritual } \\
\text { leader of the school. }\end{array}$ \\
\hline
\end{tabular}




\begin{tabular}{|c|c|c|}
\hline $\begin{array}{c}\text { STATEMENT(S) } \\
\text { FROM LONG-RANGE PLAN }\end{array}$ & $\begin{array}{c}\text { COMPARATIVE } \\
\text { STATEMENT(S) FROM JOB } \\
\text { DESCRIPTION }\end{array}$ & $\begin{array}{c}\text { COMPARATIVE } \\
\text { STATEMENT(S) FROM } \\
\text { EVALUATION } \\
\text { DOCUMENTS } \\
\end{array}$ \\
\hline $\begin{array}{l}\text { Elementary School Program: six } \\
\text { specific recommendations } \\
\text { including, update curric. guide, } \\
\text { new media center, elementary } \\
\text { counselor, career ed. program, } \\
\text { computer acquisition, furniture } \\
\text { acquisition, adjust class sizes. }\end{array}$ & $\begin{array}{l}\text { Provide leadership in the } \\
\text { development, revision, and } \\
\text { coordination of the school } \\
\text { curriculum } \\
\text { - Approve the purchase of all } \\
\text { textbooks and other instructional } \\
\text { materials. } \\
\text { - Promote a quality academic } \\
\text { educational program by obtaining the } \\
\text { necessary equipment and materials. } \\
\text { Plan an organized program for the } \\
\text { recruitment, interviewing and } \\
\text { recommendation of faculty and staff. }\end{array}$ & $\begin{array}{l}\text { - Recruits and hires good } \\
\text { personnel }\end{array}$ \\
\hline $\begin{array}{l}\text { - Satellite Elementary School: That } \\
\text { (name of school) establish a } \\
\text { satellite school program. }\end{array}$ & & \\
\hline $\begin{array}{l}\text { High School Academic Program: } \\
\text { three specific recommendations } \\
\text { including, develop a writing lab, } \\
\text { development of AP courses, } \\
\text { develop written courses of study in } \\
\text { each academic area. }\end{array}$ & $\begin{array}{l}\text { - Provide leadership in the } \\
\text { development, revision, and } \\
\text { coordination of the school } \\
\text { curriculum }\end{array}$ & \\
\hline $\begin{array}{l}\text { Business Education Program: five } \\
\text { specific recommendations } \\
\text { including, determine courses for a } \\
\text { secretarial program, create typing } \\
\text { course appropriate to business } \\
\text { track students, alternative program } \\
\text { to shorthand, accounting courses } \\
\text { for computer, investigate } \\
\text { secretarial co-op program. }\end{array}$ & $\begin{array}{l}\text { Provide leadership in the } \\
\text { development, revision, and } \\
\text { coordination of the school } \\
\text { curriculum }\end{array}$ & \\
\hline $\begin{array}{l}\text { - Computer Education: four specific } \\
\text { recommendations including, } \\
\text { multiple computer units in elem. } \\
\text { classrooms, develop desktop } \\
\text { publishing, pilot a programming } \\
\text { course in the C language, in service } \\
\text { program for elem. teachers in } \\
\text { computer ed. }\end{array}$ & $\begin{array}{l}\text { Provide leadership in the } \\
\text { development, revision, and } \\
\text { coordination of the school } \\
\text { curriculum } \\
\text { - Promote a quality academic } \\
\text { educational program by obtaining the } \\
\text { necessary equipment and materials. }\end{array}$ & \\
\hline $\begin{array}{l}\text { - Home Ec.: three specific } \\
\text { recommendations including, create } \\
\text { a home ec. suite, secure furniture } \\
\text { and equipment. }\end{array}$ & $\begin{array}{l}\text { - Provide leadership in the } \\
\text { development, revision, and } \\
\text { coordination of the school } \\
\text { curriculum } \\
\text { - Promote a quality academic } \\
\text { educational program by obtaining the } \\
\text { necessary equipment and materials. }\end{array}$ & \\
\hline
\end{tabular}




\begin{tabular}{|c|c|c|}
\hline $\begin{array}{c}\text { STATEMENT(S) } \\
\text { FROM LONG-RANGE PLAN }\end{array}$ & $\begin{array}{c}\text { COMPARATIVE } \\
\text { STATEMENT(S) FROM JOB } \\
\text { DESCRIPTION }\end{array}$ & \begin{tabular}{|c|} 
COMPARATIVE \\
STATEMENT(S) FROM \\
EVALUATION \\
DOCUMENTS \\
\end{tabular} \\
\hline $\begin{array}{l}\text { - Industrial Arts: five specific } \\
\text { recommendations including, create } \\
\text { an I.A complex, secure a teacher, } \\
\text { offer drafting, offer small power } \\
\text { sources, electronics and electricity } \\
\text { courses. }\end{array}$ & $\begin{array}{l}\text { - Provide leadership in the } \\
\text { development, revision, and } \\
\text { coordination of the school } \\
\text { curriculum } \\
\text { - Promote a quality academic } \\
\text { educational program by obtaining the } \\
\text { necessary equipment and materials. }\end{array}$ & \\
\hline $\begin{array}{l}\text { Vocational Ed.: two specific } \\
\text { recommendations, introduce a voc. } \\
\text { ed. course in carpentry and add two } \\
\text { more courses in consecutive years } \\
\text { following. }\end{array}$ & $\begin{array}{l}\text { Provide leadership in the } \\
\text { development, revision, and } \\
\text { coordination of the school } \\
\text { curriculum }\end{array}$ & \\
\hline $\begin{array}{l}\text { Physical Education and Athletic } \\
\text { Programs: four specific } \\
\text { recommendations including the } \\
\text { construction of, a gymnasium, } \\
\text { tennis courts, track, and bleachers. }\end{array}$ & & \\
\hline $\begin{array}{l}\text { - Music Program: three specific } \\
\text { recommendations including, new } \\
\text { elem. text books, establish a bell } \\
\text { choir, equipment acquisition. }\end{array}$ & $\begin{array}{l}\text { Approve the purchase of all } \\
\text { textbooks and other instructional } \\
\text { materials. }\end{array}$ & \\
\hline $\begin{array}{l}\text { Special Education: five specific } \\
\text { recommendations including, } \\
\text { expand to include severely \& } \\
\text { profoundly retarded, enhanced } \\
\text { training for spec. ed. teachers, } \\
\text { Improve EMR curric., improve } \\
\text { communication of needs of special } \\
\text { students. }\end{array}$ & $\begin{array}{l}\text { - Provide leadership in the } \\
\text { development, revision, and } \\
\text { coordination of the school } \\
\text { curriculum }\end{array}$ & \\
\hline $\begin{array}{l}\text { Library/Media: six specific goals } \\
\text { related to the development of a } \\
\text { new library/media center. }\end{array}$ & & \\
\hline $\begin{array}{l}\text { High School Accreditation: three } \\
\text { specific recommendations } \\
\text { including, written courses of study, } \\
\text { complete planned library, all new } \\
\text { teachers to acquire ACSI } \\
\text { certification. }\end{array}$ & $\begin{array}{l}\text { - Provide leadership in maintaining } \\
\text { accreditation }\end{array}$ & \\
\hline
\end{tabular}




\begin{tabular}{|c|c|c|}
\hline $\begin{array}{c}\text { STATEMENT(S) } \\
\text { FROM LONG-RANGE PLAN }\end{array}$ & $\begin{array}{c}\text { COMPARATIVE } \\
\text { STATEMENT(S) FROM JOB } \\
\text { DESCRIPTION }\end{array}$ & $\begin{array}{c}\text { COMPARATIVE } \\
\text { STATEMENT(S) FROM } \\
\text { EVALUATION } \\
\text { DOCUMENTS } \\
\end{array}$ \\
\hline $\begin{array}{l}\text { - Guidance: two specific } \\
\text { recommendations, employ a full } \\
\text { time guidance counselor and } \\
\text { provide adequate guidance and } \\
\text { career center facilities, equipment } \\
\text { and materials. }\end{array}$ & $\begin{array}{l}\text { - Plan an organized program for the } \\
\text { recruitment, interviewing and } \\
\text { recommendation of faculty and staff. } \\
\text { - Promote a quality academic } \\
\text { educational program by obtaining } \\
\text { the necessary equipment and } \\
\text { materials } \\
\text { - Determines and oversees a suitable } \\
\text { guidance program for the school. }\end{array}$ & $\begin{array}{l}\text { - Recruits and hires good } \\
\text { personnel }\end{array}$ \\
\hline $\begin{array}{l}\text { New Facilities: eleven specific } \\
\text { goals are listed relative to new } \\
\text { facilities needed for programmatic } \\
\text { changes above. }\end{array}$ & & \\
\hline $\begin{array}{l}\text { - Staff: six specific } \\
\text { recommendations are listed } \\
\text { including, recruitment of teachers } \\
\text { to fill positions created through } \\
\text { other recommendations, assistant } \\
\text { administrators in elementary and } \\
\text { high school, name discipline area } \\
\text { coordinators, train teachers for AP } \\
\text { instruction. }\end{array}$ & $\begin{array}{l}\text { - Plan an organized program for the } \\
\text { recruitment, interviewing and } \\
\text { recommendation of faculty and staff. }\end{array}$ & $\begin{array}{l}\text { - Recruits and hires good } \\
\text { personnel }\end{array}$ \\
\hline \multicolumn{3}{|l|}{ SCHOOL \#26 TOTALS } \\
\hline 16 items & 13 items - $81.25 \%$ & $\begin{array}{l}4 \text { items }-25 \% / \text { Total - } \\
53.125 \%\end{array}$ \\
\hline
\end{tabular}




\begin{tabular}{|c|c|c|}
\hline $\begin{array}{c}\text { STATEMENT(S) } \\
\text { FROM LONG-RANGE PLAN }\end{array}$ & $\begin{array}{c}\text { COMPARATIVE } \\
\text { STATEMENT(S) FROM JOB } \\
\text { DESCRIPTION }\end{array}$ & $\begin{array}{c}\text { COMPARATIVE } \\
\text { STATEMENT(S) FROM } \\
\text { EVALUATION } \\
\text { DOCUMENTS } \\
\end{array}$ \\
\hline \multicolumn{3}{|l|}{ SCHOOL \#27 } \\
\hline $\begin{array}{l}\text { - Academic Curriculum and College } \\
\text { Admissions: eight specific goals } \\
\text { including, offer a challenging, } \\
\text { motivating, Biblically strong, } \\
\text { integrated curriculum, articulate } \\
\text { the Christian basis for excellence, } \\
\text { est. a continuing curric. eval. } \\
\text { program, develop quality libraries, } \\
\text { acquire further accreditation, } \\
\text { develop technology school-wide, } \\
\text { expand program for learning } \\
\text { differences, develop college/career } \\
\text { guidance. }\end{array}$ & $\begin{array}{l}\text { Ensure the school maintains } \\
\text { accreditation with those associations, } \\
\text { as proposed by the Board of } \\
\text { Directors. } \\
\text { - Establish and ensure that the school } \\
\text { maintains a superior guidance, } \\
\text { college, and career program. } \\
\text { - Shall annually present the curriculum } \\
\text { for all campuses to the Board of } \\
\text { Directors. He is responsible for } \\
\text { establishing a curriculum that is } \\
\text { carried forth in harmony with the } \\
\text { mission statement and philosophy of } \\
\text { the school. }\end{array}$ & $\begin{array}{l}\text { - Maintains satisfactory } \\
\text { status with accreditation } \\
\text { agencies. } \\
\text { - Maintains a superior } \\
\text { guidance and college } \\
\text { placement program. } \\
\text { - Effectively presents } \\
\text { curriculum program to the } \\
\text { board annually. }\end{array}$ \\
\hline $\begin{array}{l}\text { - Spiritual and Social Formation: six } \\
\text { specific goals including, standards } \\
\text { for teaching Biblical principles in } \\
\text { every subject, est. resources for } \\
\text { spiritual assistance, provide service } \\
\text { and mission opportunities, expand } \\
\text { social programs for students and } \\
\text { families, improve parent } \\
\text { orientation, school wide spiritual } \\
\text { emphasis programs. }\end{array}$ & $\begin{array}{l}\text { Demonstrates spiritual development } \\
\text { in attitude, actions, and speech, } \\
\text { showing a consistent walk with Jesus } \\
\text { Christ. }\end{array}$ & $\begin{array}{l}\text { - Considered a spiritual } \\
\text { leader of the school. }\end{array}$ \\
\hline \multicolumn{3}{|l|}{$\begin{array}{l}\text { Co-Curricular Activities: two } \\
\text { specific goals, encourage all } \\
\text { students to participate in a variety } \\
\text { of co-curricular activities and } \\
\text { review all co-curricular activities to } \\
\text { ensure that they complement and } \\
\text { enhance the school's stated } \\
\text { mission. }\end{array}$} \\
\hline $\begin{array}{l}\text { Admission and Retention of } \\
\text { Students: two specific goals, } \\
\text { identify, attract, and retain a } \\
\text { diverse group of students from } \\
\text { Christian homes and improve } \\
\text { instruments for measuring parent } \\
\text { satisfaction. }\end{array}$ & & \\
\hline
\end{tabular}




\begin{tabular}{|c|c|c|}
\hline $\begin{array}{c}\text { STATEMENT(S) } \\
\text { FROM LONG-RANGE PLAN }\end{array}$ & $\begin{array}{c}\text { COMPARATIVE } \\
\text { STATEMENT(S) FROM JOB } \\
\text { DESCRIPTION }\end{array}$ & $\begin{array}{c}\text { COMPARATIVE } \\
\text { STATEMENT(S) FROM } \\
\text { EVALUATION } \\
\text { DOCUMENTS } \\
\end{array}$ \\
\hline $\begin{array}{l}\text { Faculty and Staff: six specific goals } \\
\text { including, recruit and retain } \\
\text { excellent faculty, improve } \\
\text { professional development, move } \\
\text { toward } 25 \% \text { of faculty holding } \\
\text { advanced degrees, develop } \\
\text { programs for obtaining and } \\
\text { training qualified subs and aides, } \\
\text { improve teacher compensation, } \\
\text { including benefits. }\end{array}$ & $\begin{array}{l}\text { The Headmaster is responsible for } \\
\text { adhering to all policies and } \\
\text { procedures established by the Board } \\
\text { of Directors regarding hiring and } \\
\text { dismissals. }\end{array}$ & $\begin{array}{l}\text { - Recruits and hires good } \\
\text { personnel. }\end{array}$ \\
\hline $\begin{array}{l}\text { Facilities: two specific goals; } \\
\text { develop a master plan for a } \\
\text { permanent campus and expand and } \\
\text { maintain elementary feeder } \\
\text { schools. }\end{array}$ & & \\
\hline $\begin{array}{l}\text { - Finance and Development: three } \\
\text { specific goals including, operate on } \\
\text { a sound financial basis, establish a } \\
\text { comprehensive development } \\
\text { program, seek to form alliances } \\
\text { with other Christian schools. }\end{array}$ & & \\
\hline $\begin{array}{l}\text { Volunteer Service: evaluate and } \\
\text { expand adult volunteer programs. }\end{array}$ & & $\begin{array}{l}\text { Involves parents in school } \\
\text { and encourages } \\
\text { volunteerism. }\end{array}$ \\
\hline \multicolumn{3}{|l|}{ SCHOOL \#27 TOTALS } \\
\hline 8 items & 3 items $-37.5 \%$ & $\begin{array}{l}4 \text { items - 50\% / Totals - } \\
43.75 \%\end{array}$ \\
\hline \multicolumn{3}{|l|}{ SCHOOL \#28 } \\
\hline $\begin{array}{l}\text { Finances: three general categories } \\
\text { of goals including, extended salary } \\
\text { and tuition plan, tuition to equal } \\
90 \% \text { of revenue, fund raising for } \\
\text { debt retirement and special } \\
\text { projects, expansion of donor base. }\end{array}$ & $\begin{array}{l}\text { - To help with fund raising for the } \\
\text { annual budget and for capital } \\
\text { improvements. } \\
\text { - To present an annual } \\
\text { recommendation to the Board for the } \\
\text { improvement of the salary schedule } \\
\text { and fringe benefits for the faculty } \\
\text { and staff. }\end{array}$ & $\begin{array}{l}\text { - No evaluation form } \\
\text { available }\end{array}$ \\
\hline
\end{tabular}




\begin{tabular}{|c|c|c|}
\hline $\begin{array}{c}\text { STATEMENT(S) } \\
\text { FROM LONG-RANGE PLAN }\end{array}$ & $\begin{array}{c}\text { COMPARATIVE } \\
\text { STATEMENT(S) FROM JOB } \\
\text { DESCRIPTION }\end{array}$ & $\begin{array}{c}\text { COMPARATIVE } \\
\text { STATEMENT(S) FROM } \\
\text { EVALUATION } \\
\text { DOCUMENTS } \\
\end{array}$ \\
\hline $\begin{array}{l}\text { Program: six general categories of } \\
\text { goals including, learning support } \\
\text { program, expanded computer use, } \\
\text { expansion and computerization, } \\
\text { curriculum development, } \\
\text { recognition of excellence, } \\
\text { individual needs of high school } \\
\text { students. }\end{array}$ & $\begin{array}{l}\text { - To lead the faculty in continuous } \\
\text { curriculum development and the } \\
\text { refinement of a distinctively } \\
\text { Christian philosophy of education }\end{array}$ & \\
\hline $\begin{array}{l}\text { Personnel: four general categories } \\
\text { of goals including, expansion of } \\
\text { administration, additional faculty, } \\
\text { review of policies and procedures, } \\
\text { improvement of fringe benefits. }\end{array}$ & $\begin{array}{l}\text { To present an annual } \\
\text { recommendation to the Board for the } \\
\text { improvement of the salary schedule } \\
\text { and fringe benefits for the faculty } \\
\text { and staff. } \\
\text { - To lead in the recruiting of a quality } \\
\text { faculty and staff. }\end{array}$ & \\
\hline $\begin{array}{l}\text { - Enrollment: one specific goal to } \\
\text { stabilize k-12 enrollment at } 500 \text {. }\end{array}$ & & \\
\hline $\begin{array}{l}\text { Facilities: one general category of } \\
\text { goals related to maintenance, } \\
\text { repair, and system renovation. } \\
\text { eight specific goals. }\end{array}$ & & \\
\hline \multirow[t]{2}{*}{$\begin{array}{l}\text { Marketing: five general categories } \\
\text { of goals including, retention of } \\
\text { students, church awareness, better } \\
\text { written communication, } \\
\text { overcoming of barriers, overall } \\
\text { promotion. }\end{array}$} & $\begin{array}{l}\text { To maintain a good program for } \\
\text { interpreting the school to its own } \\
\text { constituents, alumni, area churches, } \\
\text { and the general public. }\end{array}$ & \\
\hline & $\begin{array}{l}\text { To assist in formulating a valid five- } \\
\text { year plan for the development of the } \\
\text { school. }\end{array}$ & \\
\hline \multicolumn{3}{|l|}{ SCHOOL \#28 TOTALS } \\
\hline 6 items & $\begin{array}{l}4 \text { items - } 66.667 \% \text { / } 1 \text { planning } \\
\text { statement }\end{array}$ & $\begin{array}{l}0 \text { items }-0 \% / \text { Total - } \\
33.333 \%\end{array}$ \\
\hline \multicolumn{3}{|l|}{ SCHOOL \#29 } \\
\hline $\begin{array}{l}\text { Public Relations: review fund } \\
\text { raising events, create guidelines for } \\
\text { drama productions, spring banquet, } \\
\text { senior trip, calendar development, } \\
\text { designate a PR coordinator. }\end{array}$ & $\begin{array}{l}\text { - Assist the Board and Director of } \\
\text { Development in the implementation } \\
\text { of a sound public relations and fund- } \\
\text { raising program. } \\
\text { - Oversee the school's yearly calendar. }\end{array}$ & $\begin{array}{l}\text { - Facilitates all fund-raising } \\
\text { and development projects. }\end{array}$ \\
\hline
\end{tabular}




\begin{tabular}{|c|c|c|}
\hline $\begin{array}{c}\text { STATEMENT(S) } \\
\text { FROM LONG-RANGE PLAN }\end{array}$ & $\begin{array}{c}\text { COMPARATIVE } \\
\text { STATEMENT(S) FROM JOB } \\
\text { DESCRIPTION }\end{array}$ & $\begin{array}{c}\text { COMPARATIVE } \\
\text { STATEMENT(S) FROM } \\
\text { EVALUATION } \\
\text { DOCUMENTS } \\
\end{array}$ \\
\hline $\begin{array}{l}\text { Personnel: staff mentoring } \\
\text { program, improve staff training, } \\
\text { improve compensation, improve } \\
\text { fringe benefits, investigate merit } \\
\text { pay, establish vision for each } \\
\text { subject area. }\end{array}$ & $\begin{array}{l}\text { Provide along with school } \\
\text { administrators, for the spiritual and } \\
\text { academic in service growth of the } \\
\text { faculty. }\end{array}$ & $\begin{array}{l}\text { - Creates working conditions } \\
\text { and employment practices } \\
\text { to help attract and retain } \\
\text { qualified employees. }\end{array}$ \\
\hline $\begin{array}{l}\text { Spiritual Life: review admissions } \\
\text { policy, improve parent and teacher } \\
\text { orientation/development, institute } \\
\text { service requirement. }\end{array}$ & $\begin{array}{l}\text { Maintain a spiritually and } \\
\text { academically sound instructional } \\
\text { program throughout the school. } \\
\text { - Provide along with school } \\
\text { administrators, for the spiritual and } \\
\text { academic in service growth of the } \\
\text { faculty. } \\
\text { - Supervise student recruitment and } \\
\text { enrollment of new families. }\end{array}$ & $\begin{array}{l}\text { - Ensures the emphasis of } \\
\text { spiritual development with } \\
\text { all staff members. }\end{array}$ \\
\hline $\begin{array}{l}\text { Finance: establish admin. salary } \\
\text { range, begin funding of asset } \\
\text { depreciation, project and } \\
\text { communicate tuition growth. }\end{array}$ & & \\
\hline \multicolumn{3}{|l|}{$\begin{array}{l}\text { Maintenance: replace carpet, } \\
\text { purchase hot water storage tank, } \\
\text { renovate HS office. }\end{array}$} \\
\hline & & $\begin{array}{l}\text { Discerns the needs of the } \\
\text { school. Sets goals and } \\
\text { objectives to meet the } \\
\text { perceived needs. Carries } \\
\text { out short and long range } \\
\text { projects. }\end{array}$ \\
\hline \multicolumn{3}{|l|}{ SCHOOL \#29 TOTALS } \\
\hline 5 items & 3 items $-60 \%$ & $\begin{array}{l}3 \text { items - } 60 \% \text { / } 1 \text { planning } \\
\text { statement / Total }-60 \%\end{array}$ \\
\hline \multicolumn{3}{|l|}{ SCHOOL \#30 } \\
\hline $\begin{array}{l}\text { Affordability: refine financial aid } \\
\text { application and funding process, } \\
\text { enlist churches to help their } \\
\text { congregants. }\end{array}$ & & \\
\hline
\end{tabular}




\begin{tabular}{|c|c|c|}
\hline $\begin{array}{c}\text { STATEMENT(S) } \\
\text { FROM LONG-RANGE PLAN }\end{array}$ & $\begin{array}{c}\text { COMPARATIVE } \\
\text { STATEMENT(S) FROM JOB } \\
\text { DESCRIPTION }\end{array}$ & $\begin{array}{c}\text { COMPARATIVE } \\
\text { STATEMENT(S) FROM } \\
\text { EVALUATION } \\
\text { DOCUMENTS } \\
\end{array}$ \\
\hline $\begin{array}{l}\text { - Communication: increase } \\
\text { communication to Christian } \\
\text { community, develop brochure for } \\
\text { City Hostess, develop civic } \\
\text { presentations, establish a PR video } \\
\text { and radio spots, develop a web site, } \\
\text { offer parent seminars, develop } \\
\text { company relocation packets, } \\
\text { establish church liaisons. }\end{array}$ & $\begin{array}{l}\text { - Works with the public relations } \\
\text { committee and the director of } \\
\text { development and finance to promote } \\
\text { the various ministries of (name of } \\
\text { school). } \\
\text { - Works with the appropriate } \\
\text { administrative staff in the } \\
\text { development of curriculum, } \\
\text { programs, and parent education. }\end{array}$ & $\begin{array}{l}\text { - Communicates effectively } \\
\text { to church constituency and } \\
\text { general public, both } \\
\text { verbally and through } \\
\text { written communication. }\end{array}$ \\
\hline $\begin{array}{l}\text { Demographics: include ethnic } \\
\text { representation on board and staff, } \\
\text { recruit minority students. }\end{array}$ & & \\
\hline $\begin{array}{l}\text { - Student Recruitment: increase } \\
\text { church visits, contact all Christian } \\
\text { school students, jr. high open } \\
\text { house. }\end{array}$ & & \\
\hline $\begin{array}{l}\text { - Funding: develop oversight } \\
\text { committees, establish capital } \\
\text { campaign committee, establish } \\
\text { planned giving program. }\end{array}$ & & \\
\hline $\begin{array}{l}\text { - Public Relations: establish media } \\
\text { contacts, }\end{array}$ & & \\
\hline $\begin{array}{l}\text { - Curriculum: evaluate and } \\
\text { implement college lab } \\
\text { requirements, change history } \\
\text { teaching strategy 6-12, review } \\
\text { math curriculum, expand fine arts, } \\
\text { develop LD program, develop } \\
\text { vocational program, expand } \\
\text { science and math, increase off } \\
\text { campus courses, add general ed. } \\
\text { courses, make campus deaf- } \\
\text { friendly, expand curriculum, } \\
\text { establish a career center, offer a } \\
\text { variety of after school clubs. }\end{array}$ & $\begin{array}{l}\text { Works with the appropriate } \\
\text { administrative staff in the } \\
\text { development of curriculum, } \\
\text { programs, and parent education. }\end{array}$ & $\begin{array}{l}\text { Oversees the academic } \\
\text { program ensuring a quality } \\
\text { educational product. }\end{array}$ \\
\hline $\begin{array}{l}\text { - SCORE: improve study skills, offer } \\
\text { staff training, encourage } \\
\text { mentoring, instruct parents, train jr. } \\
\text { high staff, train adult/ business } \\
\text { mentors. }\end{array}$ & & $\begin{array}{l}\text { Oversees the academic } \\
\text { program ensuring a quality } \\
\text { educational product. }\end{array}$ \\
\hline $\begin{array}{l}\text { Staff: develop compensation for } \\
\text { co-curricular activities, hire full- } \\
\text { time guidance counselor, sign } \\
\text { language teacher. }\end{array}$ & & $\begin{array}{l}\text { - Carefully researches and } \\
\text { interviews, and } \\
\text { recommends candidates. }\end{array}$ \\
\hline
\end{tabular}




\begin{tabular}{|c|c|c|}
\hline $\begin{array}{c}\text { STATEMENT(S) } \\
\text { FROM LONG-RANGE PLAN }\end{array}$ & $\begin{array}{c}\text { COMPARATIVE } \\
\text { STATEMENT(S) FROM JOB } \\
\text { DESCRIPTION }\end{array}$ & $\begin{array}{c}\text { COMPARATIVE } \\
\text { STATEMENT(S) FROM } \\
\text { EVALUATION } \\
\text { DOCUMENTS } \\
\end{array}$ \\
\hline $\begin{array}{l}\text { ISP: improve communication, } \\
\text { participate in grant tech. project, } \\
\text { provide curriculum packages, offer } \\
\text { four educational tracks, lab science } \\
\text { course, parent training. }\end{array}$ & $\begin{array}{l}\text { Works with the public relations } \\
\text { committee and the director of } \\
\text { development and finance to promote } \\
\text { the various ministries of (name of } \\
\text { school). } \\
\text { - Works with the appropriate } \\
\text { administrative staff in the } \\
\text { development of curriculum, } \\
\text { programs, and parent education. }\end{array}$ & $\begin{array}{l}\text { - Oversees the academic } \\
\text { program ensuring a quality } \\
\text { educational product. }\end{array}$ \\
\hline $\begin{array}{l}\text { Technology: apply for available } \\
\text { grants, hold staff in services, issue } \\
\text { desktop computers for faculty. }\end{array}$ & & \\
\hline $\begin{array}{l}\text { - Educational Reputation: Improve } \\
\text { publicity, compete in academic } \\
\text { competitions. }\end{array}$ & & \\
\hline $\begin{array}{l}\text { - Facilities: conduct feasibility study, } \\
\text { identify locations for a new school } \\
\text { site, lay groundwork for capital } \\
\text { campaign, begin expansion } \\
\text { planning. }\end{array}$ & & $\begin{array}{l}\text { Makes recommendations } \\
\text { and helps implement } \\
\text { improvement regarding } \\
\text { facilities. }\end{array}$ \\
\hline \multicolumn{3}{|l|}{ SCHOOL \#30 TOTALS } \\
\hline 13 items & 3 items - $23.077 \%$ & $\begin{array}{l}6 \text { items }-46.154 \% \text { / Total - } \\
34.615 \%\end{array}$ \\
\hline \multicolumn{3}{|l|}{ SCHOOL \#31 } \\
\hline $\begin{array}{l}\text { Strategic Goal \#1: plan, organize, } \\
\text { develop and implement a facility } \\
\text { expansion and renovation plan } \\
\text { which will provide an excellent } \\
\text { learning environment for } 700 \\
\text { students. three phases with } \\
\text { specific goals listed. }\end{array}$ & & \\
\hline $\begin{array}{l}\text { - Strategic Goal \#2: create first class } \\
\text { library research centers which } \\
\text { support the curricular needs of } \\
\text { (name of school). five phases with } \\
\text { specific goals listed. }\end{array}$ & & \\
\hline
\end{tabular}




\begin{tabular}{|c|c|c|}
\hline $\begin{array}{c}\text { STATEMENT(S) } \\
\text { FROM LONG-RANGE PLAN }\end{array}$ & $\begin{array}{c}\text { COMPARATIVE } \\
\text { STATEMENT(S) FROM JOB } \\
\text { DESCRIPTION }\end{array}$ & $\begin{array}{c}\text { COMPARATIVE } \\
\text { STATEMENT(S) FROM } \\
\text { EVALUATION } \\
\text { DOCUMENTS } \\
\end{array}$ \\
\hline $\begin{array}{l}\text { Strategic Goal \#3: enable students, } \\
\text { faculty, and staff to become } \\
\text { technologically literate and } \\
\text { proficient in order to function well } \\
\text { in a technology-based society. five } \\
\text { phases with specific goals listed. }\end{array}$ & $\begin{array}{l}\text { In cooperation with the secondary } \\
\text { and elementary principals, } \\
\text { recommends to the Operations } \\
\text { Committee all courses of study, } \\
\text { curriculum guides and major changes } \\
\text { in texts. }\end{array}$ & $\begin{array}{l}\text { - In cooperation with the } \\
\text { secondary and elementary } \\
\text { principals, recommends to } \\
\text { the Operations Committee } \\
\text { all courses of study, } \\
\text { curriculum guides and } \\
\text { major changes in texts. }\end{array}$ \\
\hline $\begin{array}{l}\text { Strategic Goal \#4: strive to enable } \\
\text { students to build Christian } \\
\text { character through the application } \\
\text { of biblical truth and fulfillment of } \\
\text { the biblical command to be "salt } \\
\text { and light". five phases with specific } \\
\text { goals listed. }\end{array}$ & $\begin{array}{l}\text { Shall be responsible for the oversight } \\
\text { and coordination of the consistent } \\
\text { spiritual development of faculty, staff } \\
\text { and student body. }\end{array}$ & $\begin{array}{l}\text { Shall be responsible for the } \\
\text { oversight and coordination } \\
\text { of the consistent spiritual } \\
\text { development of faculty, } \\
\text { staff and student body. }\end{array}$ \\
\hline $\begin{array}{l}\text { - Strategic Goal \#5: foster student } \\
\text { skills in effective communication } \\
\text { through listening, reading, } \\
\text { speaking and writing. five phases } \\
\text { with specific goals listed. }\end{array}$ & $\begin{array}{l}\text { In cooperation with the secondary } \\
\text { and elementary principals, } \\
\text { recommends to the Operations } \\
\text { Committee all courses of study, } \\
\text { curriculum guides and major changes } \\
\text { in texts. }\end{array}$ & $\begin{array}{l}\text { - In cooperation with the } \\
\text { secondary and elementary } \\
\text { principals, recommends to } \\
\text { the Operations Committee } \\
\text { all courses of study, } \\
\text { curriculum guides and } \\
\text { major changes in texts. }\end{array}$ \\
\hline & $\begin{array}{l}\text { Provides leadership in designing and } \\
\text { implementing short and long range } \\
\text { goals in accordance with the mission } \\
\text { of the school. }\end{array}$ & $\begin{array}{l}\text { Provides leadership in } \\
\text { designing and } \\
\text { implementing short and } \\
\text { long range goals in } \\
\text { accordance with the } \\
\text { mission of the school. }\end{array}$ \\
\hline \multicolumn{3}{|l|}{ SCHOOL \#31 TOTALS } \\
\hline 5 items & 3 items $-60 \%$ / 1 planning statement & $\begin{array}{l}3 \text { items - } 60 \% \text { / } 1 \text { planning } \\
\text { statement / Total }-60 \%\end{array}$ \\
\hline \multicolumn{3}{|l|}{ SCHOOL \#32 } \\
\hline $\begin{array}{l}\text { Academic: nineteen specific goals } \\
\text { including expansion of course } \\
\text { offerings, acquisition of } \\
\text { equipment, upgrade of computers, } \\
\text { expansion of staff, peer evaluation, } \\
\text { admissions policy changes. }\end{array}$ & $\begin{array}{l}\text { Direct the work of } \\
\text { curriculum/textbook evaluation and } \\
\text { make the final decision regarding } \\
\text { textbook adoption or curriculum } \\
\text { change. }\end{array}$ & $\begin{array}{l}\text { - Has a pronounced interest } \\
\text { in improving the } \\
\text { instructional program. }\end{array}$ \\
\hline $\begin{array}{l}\text { - Social/Cultural: six specific goals } \\
\text { including, field trips, student } \\
\text { activities, minority recruitment, } \\
\text { CPR training, sister school } \\
\text { relationship. }\end{array}$ & & \\
\hline
\end{tabular}




\begin{tabular}{|c|c|c|}
\hline $\begin{array}{c}\text { STATEMENT(S) } \\
\text { FROM LONG-RANGE PLAN }\end{array}$ & $\begin{array}{c}\text { COMPARATIVE } \\
\text { STATEMENT(S) FROM JOB } \\
\text { DESCRIPTION }\end{array}$ & $\begin{array}{c}\text { COMPARATIVE } \\
\text { STATEMENT(S) FROM } \\
\text { EVALUATION } \\
\text { DOCUMENTS } \\
\end{array}$ \\
\hline $\begin{array}{l}\text { - Spiritual Life: five specific goals } \\
\text { including, expansion of "stretch } \\
\text { week", service projects, Bible } \\
\text { study opportunities. }\end{array}$ & & \\
\hline $\begin{array}{l}\text { Physical Facilities: seventeen } \\
\text { specific goals including, repairs } \\
\text { and replacements, expansion of } \\
\text { buildings, computer development, } \\
\text { signage, lighting and jr. high lunch } \\
\text { program. }\end{array}$ & $\begin{array}{l}\text { Be alert to building and grounds } \\
\text { maintenance needs and inform maint. } \\
\text { committee of problem areas. }\end{array}$ & \\
\hline $\begin{array}{l}\text { - General: fourteen specific goals } \\
\text { including, improving student } \\
\text { handbook, initiation of several new } \\
\text { policies, research of staff } \\
\text { compensation, expansion of media } \\
\text { center. }\end{array}$ & $\begin{array}{l}\text { Act as advisor to the board on } \\
\text { financial matters such as budget, } \\
\text { salaries, tuition, etc. }\end{array}$ & \\
\hline \multicolumn{3}{|l|}{ SCHOOL \#32 TOTALS } \\
\hline 5 items & 3 items - $60 \%$ & 1 item - $20 \%$ / Total $-40 \%$ \\
\hline \multicolumn{3}{|l|}{ TOTALS: 32 CASES } \\
\hline 219 Items & $\begin{array}{l}107 \text { Items - } 48.858 \% \\
16 \text { Planning Statements }\end{array}$ & $\begin{array}{l}48 \text { Items }-21.918 \% \\
\text { Total } 35.388 \% \\
6 \text { Planning Statements }\end{array}$ \\
\hline
\end{tabular}




\section{Data Chart - Questionnaire/Survey}

\begin{tabular}{|l|l|l|}
\hline NUM=case number & REV=date of last ACSI accred. & ITEMS 1-5 \\
CRT=certification (a=admin, & review & \\
t=teacher, $n=$ none) & MIS=mission statement & SA=strongly agree \\
DEG=degree & PLA=long range plan & A=agree \\
EXP=experience & HLP=how long has it been in place & N=neutral \\
CSA=Christian school admin. & PRE=how often reviewed & D=disagree \\
experience & JOB=elements in job description & SD=strongly disagree \\
PSE=present school experience & PFE=elements in performance eval. & \\
BOD=number of board members & BOC=board or committee evaluates & \\
\hline
\end{tabular}

\begin{tabular}{|c|c|c|c|c|c|c|c|c|c|c|c|c|c|c|c|c|c|c|c|}
\hline $\begin{array}{l}\mathrm{N} \\
\mathrm{U} \\
\mathrm{M}\end{array}$ & $\begin{array}{l}\mathrm{C} \\
\mathrm{R} \\
\mathrm{T}\end{array}$ & $\begin{array}{l}\mathrm{D} \\
\mathrm{E} \\
\mathrm{G}\end{array}$ & $\begin{array}{l}E \\
X \\
P\end{array}$ & $\begin{array}{l}\text { C } \\
\text { S } \\
\text { A }\end{array}$ & $\begin{array}{l}\text { PS } \\
\text { E }\end{array}$ & $\begin{array}{l}\text { B } \\
\text { O } \\
\text { D }\end{array}$ & $\begin{array}{l}\mathrm{R} \\
\mathrm{E} \\
\mathrm{V}\end{array}$ & $\begin{array}{l}\text { M } \\
\text { I } \\
\text { S }\end{array}$ & $\begin{array}{l}\text { P } \\
\text { L } \\
\text { A }\end{array}$ & $\begin{array}{l}\mathrm{H} \\
\mathrm{L} \\
\mathrm{P}\end{array}$ & $\begin{array}{l}\mathrm{P} \\
\mathrm{R} \\
\mathrm{E}\end{array}$ & $\begin{array}{l}\text { JO } \\
\text { B }\end{array}$ & $\begin{array}{l}\mathrm{PF} \\
\mathrm{E}\end{array}$ & $\begin{array}{l}\mathrm{B} \\
\mathrm{O} \\
\mathrm{C}\end{array}$ & 1 & 2 & 3 & 4 & 5 \\
\hline 1 & $\mathrm{a}$ & $\begin{array}{l}\mathrm{m} \\
\mathrm{a}\end{array}$ & 22 & 18 & 7 & 9 & 94 & $\mathrm{y}$ & $\mathrm{y}$ & 5 & $\begin{array}{l}12 \\
+\end{array}$ & $\mathrm{y}$ & $y$ & $\mathrm{y}$ & $\mathrm{sa}$ & $\mathrm{sa}$ & $\mathrm{a}$ & $\mathrm{a}$ & $\mathrm{sd}$ \\
\hline 2 & $\mathrm{a}$ & $\begin{array}{l}\mathrm{m} \\
\mathrm{a}\end{array}$ & 37 & 30 & 17 & 15 & 88 & $\mathrm{y}$ & $\mathrm{y}$ & 4 & 12 & $\mathrm{n}$ & $\mathrm{n}$ & $\mathrm{y}$ & $\mathrm{sa}$ & $\mathrm{sa}$ & $\mathrm{sa}$ & $\mathrm{sa}$ & $\mathrm{sd}$ \\
\hline 3 & $\mathrm{a}$ & $\mathrm{ms}$ & 21 & 12 & 5 & 9 & 95 & $\mathrm{y}$ & $\mathrm{n}$ ? & 3 & $\begin{array}{l}12 \\
+\end{array}$ & $\mathrm{y}$ & $\mathrm{n}$ & $\mathrm{y}$ ? & $\mathrm{a}$ & $\mathrm{a}$ & $\mathrm{n}$ & $\mathrm{n}$ & $\mathrm{d}$ \\
\hline 4 & $\mathrm{a}$ & $\begin{array}{l}\mathrm{m} \\
\mathrm{a}\end{array}$ & 20 & 10 & 10 & 12 & 96 & $\mathrm{y}$ & $\mathrm{y}$ & 1 & $\mathrm{n}$ ? & $\mathrm{n}$ & $\mathrm{n}$ & $\mathrm{y}$ & sa & $\mathrm{sa}$ & $\mathrm{a}$ & $\mathrm{a}$ & $\mathrm{d}$ \\
\hline 5 & $\mathrm{a}$ & $\mathrm{pd}$ & 22 & 21 & 6 & 13 & 87 & $\mathrm{y}$ & $\mathrm{y}$ & 2 & 12 & $\mathrm{n}$ & $\mathrm{n}$ & $\mathrm{y}$ & $\mathrm{sa}$ & $\mathrm{sa}$ & $\mathrm{sa}$ & $\mathrm{sa}$ & $\mathrm{sd}$ \\
\hline 6 & $\mathrm{a}$ & bs & 27 & 4 & $\begin{array}{l}4 \\
22\end{array}$ & 10 & 94 & $\mathrm{y}$ & $\mathrm{y}$ & 4 & 12 & $\mathrm{y}$ & $\mathrm{n}$ & $\mathrm{y}$ & sa & $\mathrm{sa}$ & $\mathrm{a}$ & $\mathrm{a}$ & $\mathrm{d}$ \\
\hline 7 & $\mathrm{a}$ & $\begin{array}{l}\mathrm{m} \\
\mathrm{e}\end{array}$ & 17 & 15 & 15 & 12 & 94 & $\mathrm{y}$ & $\mathrm{y}$ & 3 & $\begin{array}{l}12 \\
+\end{array}$ & $\mathrm{y}$ & $\mathrm{n}$ & $\mathrm{y}$ & $\mathrm{a}$ & $\mathrm{a}$ & $\mathrm{a}$ & $\mathrm{a}$ & $\mathrm{d}$ \\
\hline 8 & \begin{tabular}{|l} 
ps \\
$\mathrm{y}$
\end{tabular} & $\mathrm{pd}$ & 3 & 3 & 3 & 11 & 95 & $\mathrm{y}$ & $\mathrm{y}$ & 2 & 12 & $\mathrm{y}$ & $y$ & $\mathrm{y}$ & sa & $\mathrm{sa}$ & $\mathrm{sa}$ & sa & $\mathrm{d}$ \\
\hline 9 & $\mathrm{a}$ & $\mathrm{pd}$ & 9 & 3 & 1 & 9 & 94 & $\mathrm{y}$ & $\mathrm{y}$ & 4 & 12 & $\mathrm{n}$ & $\mathrm{n}$ & $\mathrm{y}$ & sa & $\mathrm{sa}$ & $\mathrm{sa}$ & sa & $\mathrm{sd}$ \\
\hline 10 & $\mathrm{a}$ & $\begin{array}{l}\mathrm{m} \\
\mathrm{a}\end{array}$ & 18 & 10 & 1 & 9 & 95 & $\mathrm{y}$ & $\mathrm{n}$ ? & & & & & & $\mathrm{sa}$ & $\mathrm{sa}$ & $\mathrm{sa}$ & sa & $\mathrm{n}$ \\
\hline 11 & $\mathrm{a}$ & $\begin{array}{l}\mathrm{m} \\
\mathrm{a}\end{array}$ & 24 & 24 & 19 & 7 & 89 & $\mathrm{y}$ & $\mathrm{y}$ & 1 & 12 & $\mathrm{y}$ & $\mathrm{n}$ & $\mathrm{n}$ & sa & sa & $\mathrm{sa}$ & sa & $\mathrm{d}$ \\
\hline 12 & $\mathrm{a}$ & $\mathrm{mr}$ & 22 & 20 & $\begin{array}{l}22 \\
20\end{array}$ & 5 & 94 & $\mathrm{y}$ & $\mathrm{y}$ & 3 & 6 & $\mathrm{n}$ & $\mathrm{n}$ & $\mathrm{y}$ & sa & $\mathrm{a}$ & $\mathrm{a}$ & $\mathrm{a}$ & $\mathrm{d}$ \\
\hline 13 & $\mathrm{a}$ & $\begin{array}{l}\mathrm{m} \\
\mathrm{a}\end{array}$ & 19 & 6 & $\begin{array}{l}6 \\
15\end{array}$ & & 94 & $\mathrm{y}$ & $\mathrm{y}$ & 3 & 12 & $\mathrm{n}$ & $\mathrm{n}$ & $\mathrm{y}$ & $\mathrm{sa}$ & $\mathrm{sa}$ & $\mathrm{n}$ & $\mathrm{sd}$ & $\mathrm{sd}$ \\
\hline 14 & $\mathrm{a}$ & ed & 38 & 18 & 18 & 12 & 93 & $\mathrm{y}$ & $\mathrm{y}$ & 1 & 12 & $\mathrm{n}$ & $\mathrm{n}$ & $\mathrm{y}$ & $\mathrm{sa}$ & $\mathrm{sa}$ & a & $\mathrm{a}$ & $\mathrm{d}$ \\
\hline
\end{tabular}




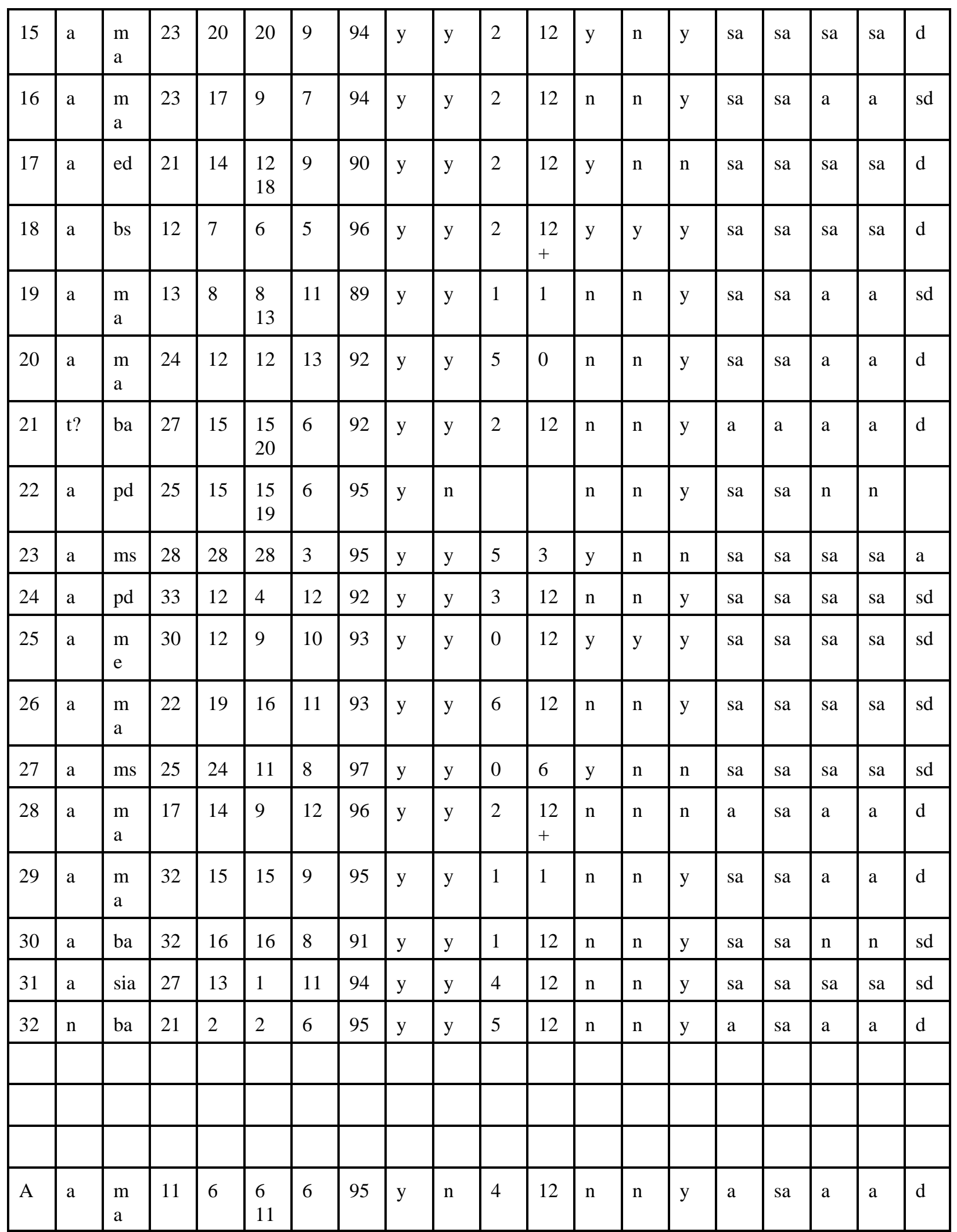




\begin{tabular}{|c|c|c|c|c|c|c|c|c|c|c|c|c|c|c|c|c|c|}
\hline B & $\mathrm{a}$ & $\mathrm{ms}$ & 26 & 20 & 5 & 7 & $?$ & $\mathrm{y}$ & $\mathrm{n}$ & & & & sa & sa & $\mathrm{a}$ & $\mathrm{n}$ & $\mathrm{sd}$ \\
\hline $\mathrm{C}$ & $\mathrm{a}$ & $\begin{array}{l}\mathrm{m} \\
\mathrm{a}\end{array}$ & 14 & 8 & $\begin{array}{l}8 \\
10\end{array}$ & 6 & & $\mathrm{y}$ & $\mathrm{n}$ & & & & $\mathrm{a}$ & $\mathrm{sa}$ & $\mathrm{sa}$ & $\mathrm{a}$ & $\mathrm{d}$ \\
\hline $\mathrm{D}$ & $\mathrm{a}$ & $\begin{array}{l}\mathrm{m} \\
\mathrm{a}\end{array}$ & 11 & 8 & $\begin{array}{l}8 \\
11\end{array}$ & 8 & 93 & $\mathrm{y}$ & $\mathrm{n}$ & & & & $\mathrm{a}$ & sa & $\mathrm{a}$ & $\mathrm{sa}$ & \\
\hline E & $\mathrm{a}$ & $\begin{array}{l}a b \\
d\end{array}$ & 17 & 14 & $\begin{array}{l}13 \\
14\end{array}$ & 9 & 93 & $\mathrm{y}$ & $\mathrm{n}$ & & & & $\mathrm{sa}$ & $\mathrm{sa}$ & sa & $\mathrm{sa}$ & $\mathrm{d}$ \\
\hline $\mathrm{F}$ & $\mathrm{a}$ & $\begin{array}{l}\text { es } \\
\text { a }\end{array}$ & 10 & 1 & 1 & 4 & 96 & $\mathrm{y}$ & $\mathrm{n}$ & 1 & r & $\mathrm{y}$ & sa & $\mathrm{sa}$ & sa & $\mathrm{sa}$ & $\mathrm{d}$ \\
\hline $\mathrm{G}$ & $\mathrm{a}$ & $\begin{array}{l}\mathrm{m} \\
\mathrm{a}\end{array}$ & 24 & 13 & $\begin{array}{l}13 \\
14\end{array}$ & 9 & 95 & $\mathrm{y}$ & $\mathrm{n}$ & & & & $\mathrm{a}$ & $\mathrm{sa}$ & $\mathrm{a}$ & $\mathrm{a}$ & $\mathrm{d}$ \\
\hline $\begin{array}{l}\mathrm{H} \\
*\end{array}$ & $\mathrm{a}$ & $\mathrm{pd}$ & 26 & 25 & 1 & 6 & 94 & $\mathrm{y}$ & $\mathrm{n}$ & 1 & $\mathrm{r}$ & $\mathrm{y}$ & $\mathrm{sa}$ & sa & $\mathrm{sa}$ & $\mathrm{sa}$ & $\mathrm{sd}$ \\
\hline I & $\mathrm{a}$ & $\begin{array}{l}\mathrm{m} \\
\mathrm{e}\end{array}$ & 25 & 10 & 2 & 9 & 95 & $\mathrm{y}$ & $\mathrm{n}$ & 1 & $r$ & $y$ & $\mathrm{sa}$ & sa & $\mathrm{a}$ & $\mathrm{a}$ & $\mathrm{d}$ \\
\hline
\end{tabular}




\section{Statement 1}

Schools should develop a written long-range plan.

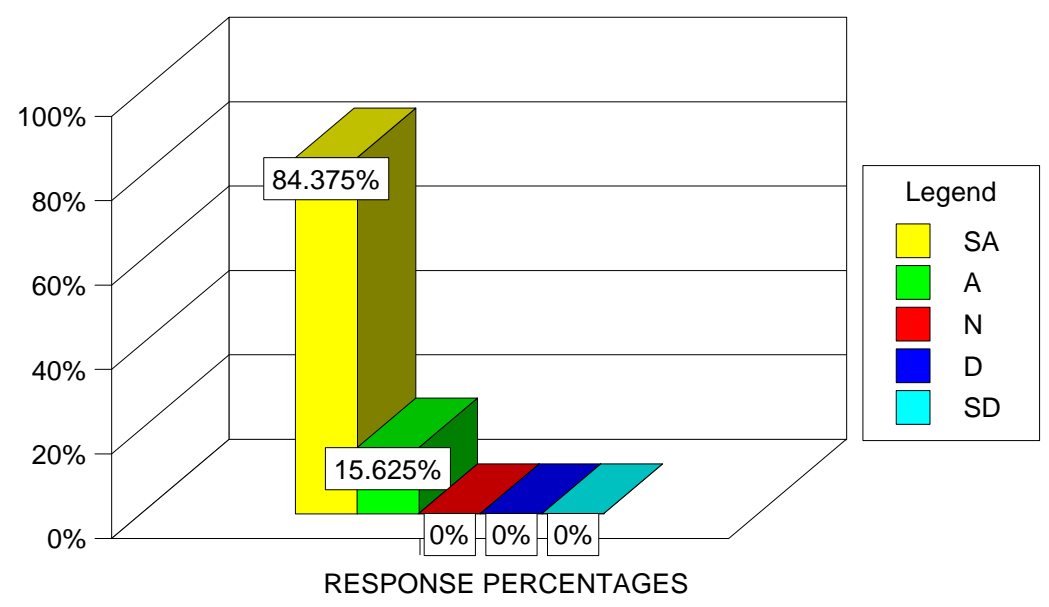

\section{Statement 2}

Long-range plans should reflect the mission of the school.

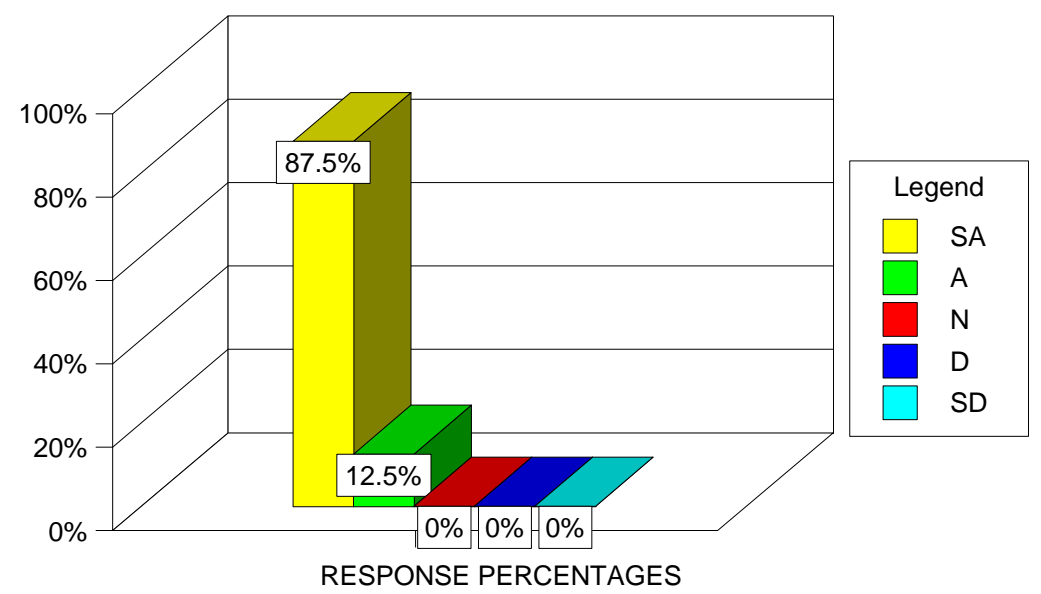




\section{Statement 3}

Implementation of the long-range plan is a major responsibility of the administration.

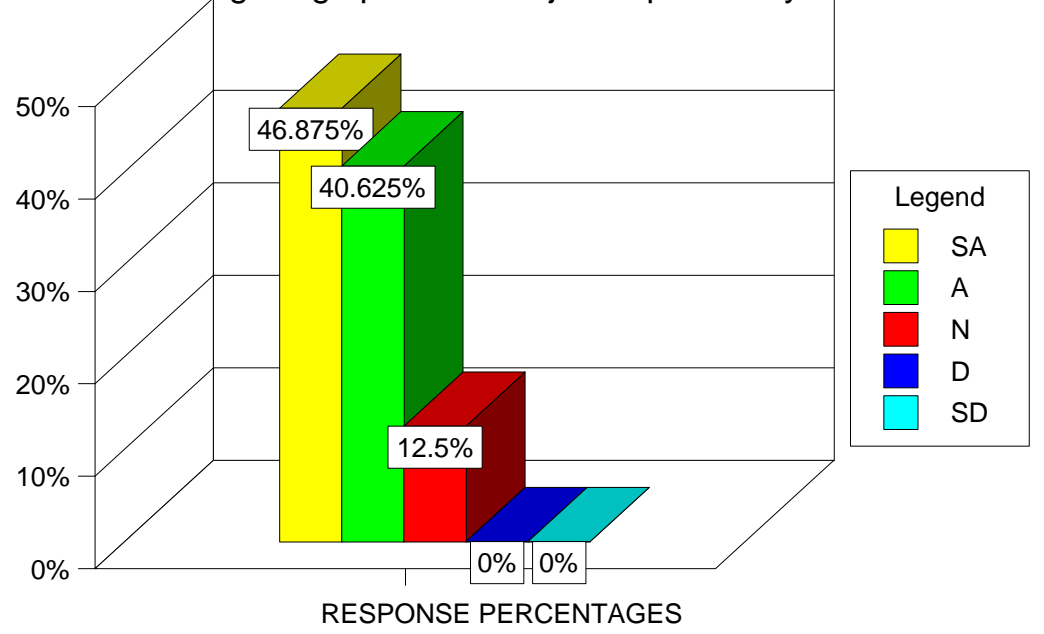

\section{Statement 4}

The administration should be held accountable for the implementation of the long-range plan.

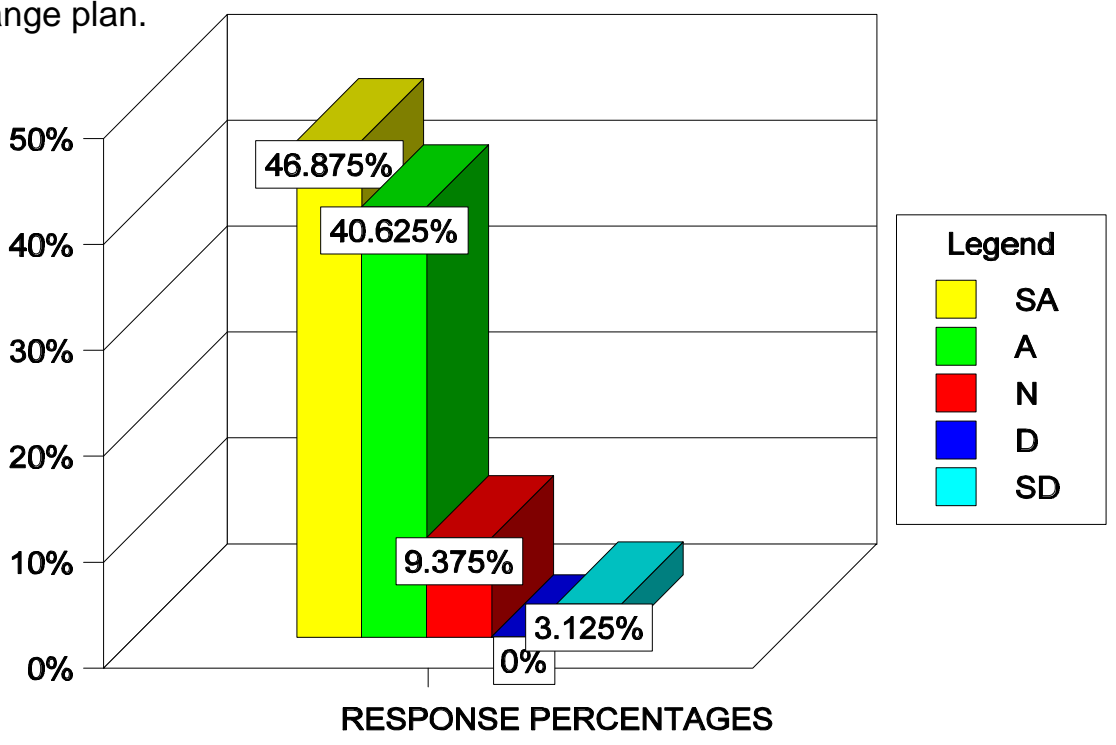


Statement 5

The exercise of planning helps to clarify the school's mission, but formal implementation is not really necessary.

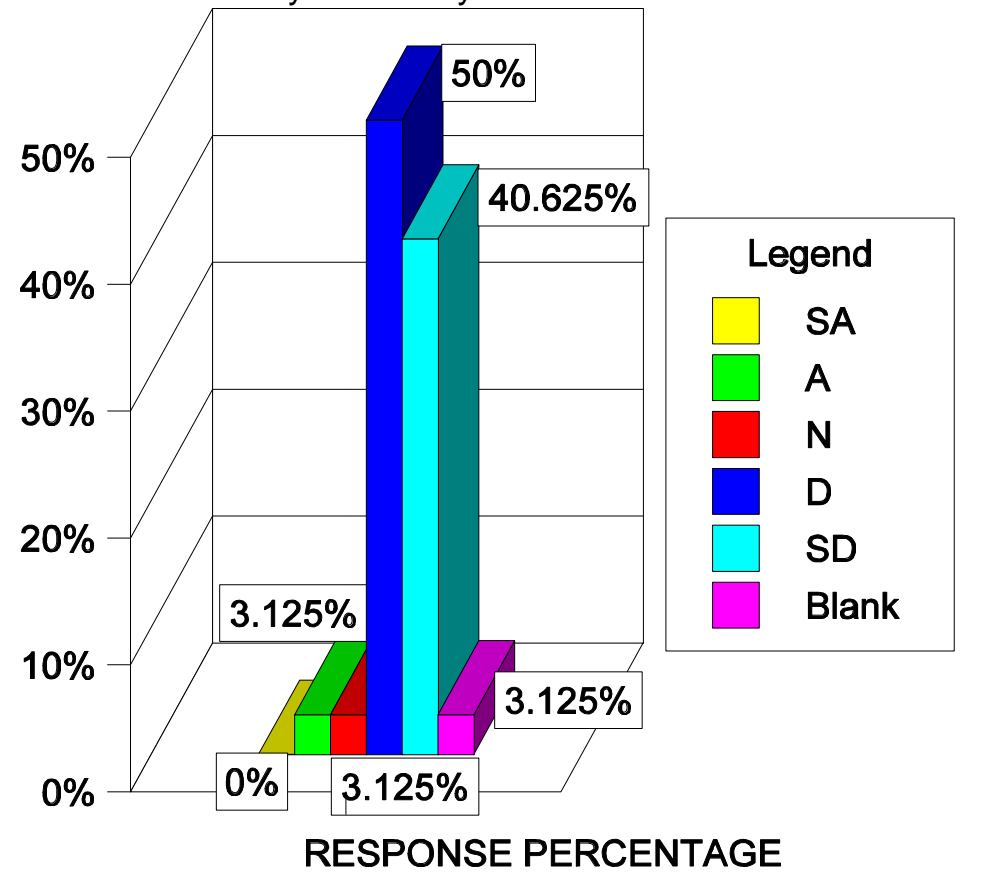




\section{BIBLIOGRAPHY}

Al-Khalaf, Abdullah M. (1994). Factors That Affect the Success and Failure of TQM Implementation in Small United States Cities. Dissertation Abstracts International 56 (01A). (AAI 9521458 FirstSearch).

Allmon, Nancy Gehret. (1996). The Perceived Impact of Strategic Planning on Pennsylvania Public Schools. Dissertation Abstracts International 57 (10A). (AAG 9709171 FirstSearch).

Ansoff, H.I. (1988). The New Corporate Strategy. New York: Wiley.

Baldwin, Mark D. (1994). Implementation of Strategic Planning in a Public School Setting: A Case Study. Dissertation Abstracts International 55 (04). (AAC 9424718 ProQuest).

Barnard, Chester I. (1968). The Functions of the Executive. Cambridge: Howard University Press.

Bashan, Vickie P. (1989). A Study of the Status of Strategic Planning in Kentucky School Districts. Dissertation Abstracts International 50 (04). (ACC 8914132 ProQuest).

Bastin, Mark Fletcher. (1996). The Effects of Status, Participation, Coercion, Knowledge and Time on Maintaining Consensus-Based Agreement in Planning Groups (Strategic Planning). Dissertation Abstracts International 57 (09A). (AAG 9704744 FirstSearch).

Bertot, John Carlo. (1996). The Impact of Information Resources Management on Federal Agency Strategic Objective Attainment: An Empirical Analysis. Dissertation Abstracts International 58 (07A). (AAG 9737834 FirstSearch).

The Bible. New American Standard Version.

Bingham, Wayne Douglas. (1996). Strategic Planning: A Process for Restructuring the Public Schools and Improving Community Support. Dissertation Abstracts International 57 (04A). (AAG 9627527 FirstSearch).

Brackett, Vivian Sherill Snelling. (1997). The South Carolina District Strategic and School Renewal Planning Process in Selected Districts and Schools (Restructuring, School Districts, Site-Based Management). Dissertation Abstracts International 58 (06A). (AAG 9738218 FirstSearch). 
Brews, Peter John. (1996). Strategic Ends and Means Specificity, Firm Performance, and Environments (Business Environment, Logical Incrementalism). Dissertation Abstracts International 57 (10A). (AAG 9709422 FirstSearch).

Brumfield, Jennifer S. (1996). Community Members' Perceptions of the Role of a Deliberative Planning Process in Their School-Community (Strategic Planning). Dissertation Abstracts International 57 (09A). (AAG 9704746 FirstSearch).

Burgess, Donald Dean. (1997). A Strategic Ministry Plan for Church Dynamics International (Strategic Planning). Dissertation Abstracts International 58 (03A). (AAG 9727155 FirstSearch).

Busler, Brian Scott. (1992). The Role of Strategic Planning and Its Effect on DecisionMaking in Wisconsin Public Schools. Dissertation Abstracts International 53 (07). (AAC 9223867 ProQuest).

Caplow, Theodore, (1983). Managing An Organization. Hold, Rinehart, and Winston. U.S.: The Dryden Press Saunders College Publishing.

Caradonio, James Anthony. (1991). An Evaluation of Key Results Planning in the Cambridge Public Schools (Massachusetts, Planning Processes). Dissertation Abstracts International 52 (06). (ACC 9132333 ProQuest).

Chandler, A., Jr. (1977). The Visible Hand: The Managerial Revolution in America. Cambridge: Belknap Press.

Chandler, Patricia Elaine. (1990). The Role of Strategic Planning in the Accreditation Process of Texas Public Schools. Dissertation Abstracts International 51 (10). (AAC 9107342 ProQuest).

Chaskin, Robert J. (1996). Grassroots Development From the Top Down: Democratic Principles and Organizational Dynamics in a Community Development Initiative. Dissertation Abstracts International 57 (11A). (AAG 9711169 FirstSearch).

Chieuw, Juliet Sue Fun. (1991). An Alternative Approach to Educational Planning Based on a Conceptual Framework of the Educational System as Dynamic: A Theoretical Study (System Dynamics). Dissertation Abstracts International 52 (10). (AAC 9209109 ProQuest).

Cissell, Homer Leo, Jr. (1993, February). The Relationship of Locus-of-Control to Strategic Planning Behaviors of Administrators of Post Secondary Occupational Programs in Illinois Community Colleges. Dissertation Abstracts International 53 (08). (AAC 9239708 ProQuest). 
Cleland, David I. and King, William R. (1974, June). Developing a Planning Culture for More Effective Strategic Planning. Long Range Planning, Vol. 7, No. 7.

Corrigan, Gregory M. (1995). Action Research in a Parochial School: A Study of School Culture. Dissertation Abstracts International 58 (06A). (AAG 9737497 FirstSearch).

Cowles, James Arthur. (1991). Factors Affecting Board of Education Selection of and Satisfaction with a Superintendent. Dissertation Abstracts International 52 (06). (AAC 9134247 ProQuest).

Cusack, Thomas Francis. (1996). An Analysis of Components and Characteristics Developed in Selected School District Strategic Plans. Dissertation Abstracts International 57 (07A). (AAG 9638283 FirstSearch).

Cuthbert, Ronald Hugh. (1996). The Strategic Planning Process of Agricultural Niche Marketers: A Case Study Approach.

Daake, Donald Dean. (1995). An Investigation of the Utilization of Information in Strategic Planning Within a Loosely Coupled Organization. Dissertation Abstracts International 56 (11A). (AAI 9609138 FirstSearch).

Daniel, James Thomas. (1995). A Case Study of Implementing Technology Within a School District's Five-Year Strategic Plan. Dissertation Abstracts International 56 (09A). (AAI 9600832 FirstSearch).

Daw, Curtis David. (1996). Creating A Transformational Environment in a Public Senior College (Leadership). Dissertation Abstracts International 57 (03A). (AAI 9620939 FirstSearch).

Desloriers, Vicki Russell. (1993). An Examination of the Strategic Planning Process at Endicott College: A Case Study of Decision-Making to Cope with Change (Massachusetts). Dissertation Abstracts International 54 (01). (AAC 9314613 ProQuest).

Dievler, Anne. (1996). The Politics of Public Health Policy in an Urban Bureaucracy: HIV Prevention, Tuberculosis Control, and Immunization Programs in Washington, D.C. (Immune Deficiency). Dissertation Abstracts International 57 (01B). (AAI 9617505 FirstSearch).

Donsky, Aaron P. (1994). IPEM: An Integrated Planning Effectiveness Model. (Reports - Descriptive No. 141). Florida: Author. 
Dottin, Erskine S. (1994, February). Help Wanted; Philosophers of Education for National Accreditation. Paper presented at the Annual Meeting of the Southeast Philosophy of Education Society, Gainesville, Fl.

Dougherty, Michael John. (1995). The Strategic Planning Role Perceptions of Virginia Local Government Chief Executive Officers. Dissertation Abstracts International 56 (07A). (AAI 9538598 FirstSearch).

Drucker, Peter F. (1974). Management: Tasks, Responsibilities, Practices. New York: Harper and Row.

Falsey, Thomas A., (1989). Corporate Philosophies \& Mission Statements: a Survey Guide for Corporate Communications \& Management. Quorum Books, U.S.: Greenwood Publishing Group, Incorporated.

Ferguson, George A. and Takane, Yoshio. (1989). Statistical Analysis in Psychology and Education. New York: McGraw Hill Publishing Co.

Franicola, Janet Louise. (1996). A Study of the impact of Strategic Management as it is Used by Local Education Association Leaders in Pennsylvania to Prepare Their Members for the Educational Challenges of the Twenty-First Century. Dissertation Abstracts International 57 (07A). (AAG 9637863 FirstSearch).

Freericks, Catherine Marie. (1991). An Analytical Case Study of Strategic Planning Models in Selected Maricopa County School Districts. Dissertation Abstracts International 52 (06). (AAC 9134859 ProQuest).

Garansuay, Ruben. (1997). Comparison of Total Quality Management Practices in Selected Organizations (Leadership). Dissertation Abstracts International 58 (07A). (AAG 9800674 FirstSearch).

Gabrielson, Marie Roseann. (1989). How School District Superintendents Use Power Strategies to Implement Planned Change. Dissertation Abstracts International 50 (05). (ACC 8917609 ProQuest).

Geddes, Lindsay, ed. (1991). Strategic Planning for Action and Results. New York: The Conference Board, Inc.

Gee, Jacqueline Arleah. (1994). Planning for Education in Alberta: A Case Study (Strategic Planning). Dissertation Abstracts International, 56 (03). (AAC NN95298 ProQuest). 
Gilbert, Daniel R. (1992). The Twilight of Corporate Strategy. New York: Oxford University Press.

Goldberg, Beverly, and Sifonis, John G. (1994). Dynamic Planning: The Art of Managing Beyond Tomorrow. New York: Oxford University Press.

Grab, Friedrich Otto Rudi. (1993). The Status of the Strategic-Planning Process and Its Impact on the Quality of Planning Practices Used in Alberta School Systems (Strategic Planning). Dissertation Abstracts International 54 (04). (AAC 9324834 ProQuest).

Graham, John W. and Wendy C. Havlick. (1994). Mission Statements: A Guide to the Corporate \& Nonprofit Sectors. (Vol. 900, p. 576). Reference Library of Social Science. New York: Garland Publishing, Incorporated.

Granger, Christine Louise. (1996). Strategic Economic Development Planning in a Rural Community: Probems and Possibilities for Collaborative Planning Within Fresno County, California.

Gullick, Thomas Harold. (1995, July). An Analysis of the Knowledge, Preparedness and Perceptions of Superintendents Toward Site-Based Management. Dissertation Abstracts International 56 (01). (AAC 9517928 ProQuest).

Hall, Gregory James. (1994). Strategic Planning: A Case Study of Behavioral Influences in the Administrative Decisions of Middle Managers In Small Independent Colleges. Dissertation Abstracts International 55 (11). (AAC 9510480 ProQuest).

Hamilton, Douglas N. (1991). The Meaning in Planning: An Interpretive Study of Organizational Planning in a School Board. Dissertation Abstracts International 53 (02). (AAC NN66001 ProQuest).

Harvey, Bryan Curtis. (1997). Starting Right: Diagnosing Institutional Readiness to Engage in Successful Strategic Planning. Dissertation Abstracts International 58 (06A). (AAG 9737532 FirstSearch).

Haskins, Susan Alice. (1992, December). The Impact of the Strategic Planning Process on the Daily Operations of the Schools Within the Tumwater School District (Washington). Dissertation Abstracts International 53 (06). (AAC 9231337 ProQuest).

Hennon, John G. (1994). Use of Information in Strategic Planning by Pennsylvania School Districts. Dissertation Abstracts International, 56 (01). (AAC 9521408 ProQuest). 
Higgins, J. C. (1980). Strategic and Operational Planning Systems: Principals and Practice. Englewood Cliffs, N.J: Prentice Hall International.

Hightower, Len. (1992). An Analysis of the Strategic Planning Literature and Its Relationship to Planning Practices at Small Independent Colleges and Universities. Dissertation Abstracts International 52 (10). (AAC 9207263 ProQuest).

Hippert, Linda Buchek. (1997). Perceptions of Superintendents in Pennsylvania Relative to the Strategic Planning Process. Dissertation Abstracts International 58 (03A). (AAG 9725222 FirstSearch).

Hoehner, Patricia Louise. (1997). Restructuring in a Rural Nebraska School (Rural Education). Dissertation Abstracts International 58 (06A). (AAG 9737497 First Search).

Hofer, Charles W., and Schendel, Dan; (1978). Strategy Formulation: Analytical Concepts. St. Paul.

Hoffman, Thomas Alan. (1996). Strategic Planning in Education: A Study of Intermediate Agencies (Education Agencies, Iowa). Dissertation Abstracts International 57 (09A). (AAG 9704256 FirstSearch).

Hoy, Wayne K. and Miskel, Cecil G. (1987). Educational Administration: Theory Research and Practice. New York: Random House.

Hrebiniak, Lawrence G. and Joyce, William F. (1981). Implementing Strategy. New York: MacMillan.

Huang, Chaomeng. (1997). The Effects of Strategic Planning: Perceptions of the Florida State Managers. Dissertation Abstracts International 58 (08A). (AAG 9806040 FirstSearch).

Ingle, Alan Lee. (1991). The Relationship of Strategic Planning Models to Organizational Effectiveness. Dissertation, West Virginia University.

Jaconette, Joseph Michael. (1995). A Case Study of a School District: Integrating Strategies for Organizational Change, Utilizing Collaborative Bargaining and LongRange Strategic Planning. Dissertation Abstracts International 56 (09A). (AAI 9602452 FirstSearch).

Jansante, Zeb R. (1996). A Descriptive Study of the Customers' Perceptions of the Degree of the Implementation of Quality Management Practices in Selected Pennsylvania Blue Ribbon School Districts (W. Edwards Deming, Students, Parents, 
School Boards). Dissertation Abstracts International 57 (12A). (AAG 9715497 FirstSearch).

Johnson, Kay Eileen. (1990). A Case Study of the Role of a School-Based Management Team in Changing a School Culture. Dissertation Abstracts International 51 (05). (AAC 9031024 ProQuest).

Kallman, Ernest A., Reinhorth, Leon, and Shapiro, Jack H. (1981). The Practice of Planning: Strategic, Administrative and Operational. Van Nostrand Reinhold Co.

Keller, George. (1983). Academic Strategy. Baltimore: The Johns Hopkins University Press.

Kemm, Elizabeth. (1997). The Effects of Using Information Technology to Support Evaluation of Feedback and Implementation of Adjustments in an Organization's Strategic Planning Process. Dissertation Abstracts International 58 (03A). (AAG 9727788 FirstSearch).

Keinel, Paul A. (1978). The Philosophy of Christian School Education. Whittier, CA: ACSI Publications.

Kimball, David C. (1992). An Examination of the Distinction Between a Company Mission and a Written Mission Statement Within the Strategic Management Process: A Survey of Planning Forum Executives in the New York Area. Dissertation Abstracts International 57 (10A). (AAG 9707523 FirstSearch).

Krejcie, Robert V. and Morgan, Daryle W. (1970). "Determining Sample Size for Research Activities". Educational and Psychological Measurement. Vol. 30, pp. 607610.

Lawson, Philip Andrew. (1996). Managing Strategic Change: The ABCs of the "Whys" and "Hows" (Planning). Dissertation Abstracts International 57 (11A). (AAG 9712960 FirstSearch).

Liburd, Vincent Roy. (1996). A Study of Organizational Change in a Large Religious Organization (United Methodist Church). Dissertation Abstracts International 58 (01A). (AAG 9719776 FirstSearch).

Link, William James, Jr. (1995). Strategic Planning: Administrators' Expectations, Perceptions and Efforts in One Delaware School District. Dissertation Abstracts International 57 (02A). (AAI 9619077 FirstSearch). 
Livesey, Jerald William. (1990). A Description of Strategic Planning Practices Among Selected California Public School Districts. Dissertation Abstracts International 52 (02). (AAC 9120333 ProQuest).

Lorange, Peter. (1981). Implementation of Strategic Planning. Englewood Cliffs, New Jersey: Prentice Hall.

Lorange, Peter. (1980). Corporate Planning: An Executive Viewpoint, Englewood Cliffs, N.J.: Prentice Hall.

Lovinguth, Sandra J. (1996). Strategic Planning Outcomes at Four-Year Private Colleges and Universities (Organizational Effectiveness). Dissertation Abstracts International 57 (10A). (AAG 9710957 FirstSearch).

Martinek, Cynthia Leonard. (1996). The Superintendency: An Analysis of Leadership Roles and Gender Differences (Transformational Leadership). Dissertation Abstracts International 57 (09A). (AAG 9704259 FirstSearch).

McCray, Nelson Grant. (1997). The Identification of Critical Success Factors and Commitment to Goals: Does Strategic Planning Make a Difference in Selected Ohio School Districts. Dissertation Abstracts International 58 (05A). (AAG 9732658 FirstSearch).

McDaniel, Dayna Marlene. (1997). Effective total Quality Management Implementation by Capital City Governments (Local Government). Dissertation Abstracts International $\underline{58}$ (06A). (AAG 9735731 FirstSearch).

McDonald, Dennis J. (1996). Total Quality Management: A Case Study of the Cherry Hill Public Schools, Cherry Hill, New Jersey. Dissertation Abstracts International 57 (11A). (AAG 9713885 FirstSearch).

McQueen, William Bryant. (1996). An Identification of Strategic Planning Components and Processes Among Newly Formed Nonprofit Organizations in the Greater Cincinnati Area (Ohio). Dissertation Abstracts International 57 (03A). (AAI 9620947 FirstSearch).

Mecca, Thomas Vincent. (1993). A Case Study of the Application of the Ed Quest Strategic Planning Model in a Public Two-Year College. (Volumes I and II). Dissertation Abstracts International 54 (11). (AAC 9410029 ProQuest).

Miles, Bruce H. (1993, April). Performance Based Supervision And Employee Review Techniques for Special Education Supervisors \& Administrators. Paper presented at the Annual Meeting of the Council for Exceptional Children, San Antonio, TX. 
Mintzberg, Henry. (1994). The Rise and Fall of Strategic Planning. New York: The Free Press.

Modica, Cheryl Anne. (1997). Models of Effectiveness as Decision-Making Tools: A Study of Primary Care Association Networks. Dissertation Abstracts International 58 (01B). (AAG 9717733 FirstSearch).

Moo, G. Gregory. (1991). Toward a Synthesis of Strategic Planning and Organization Development (Planned Change). Dissertation Abstracts International 52 (12). (AAC 921496 ProQuest).

Moore, J. I. (1992). Writers on Strategy and Strategic Management. New York: Penguin Books.

Moore, Sue Hodges. (1995, January). Strategic Planning, Total Quality Management, and Quality Conceptions in Institutions of Higher Education: An Exploratory Analysis. Dissertation Abstracts International 55 (07). (AAC 9433309 ProQuest).

Mosley, Dwight Eugene. (1994). A Case Study of Strategic Planning in the School of Education at a Midwestern University. Dissertation Abstracts International, 56 (03). (AAI 9525767 ProQuest).

Naylor, Thomas H. (ed.) (1979). Corporate Planning Models. Reading, Mass: AddisonWesley Publishing Co.

Naylor, Thomas H. and Celia Thomas (ed.). (1984). Optimization Models for Strategic Planning. Amsterdam: Elsevier Science Publishers B.V. (North-Holland).

Nerone, Frederick A. (1997). Applying the Strategic Planning Process to Small Business Enterprises. Dissertation Abstracts International 58 (01A). (AAG 9720502 FirstSearch).

Nessmith, Paula F. (1992). An Analysis of the Strategic Planning Process as Applied to the School Board of Palm Beach County (Florida). Dissertation Abstracts International $\underline{53}$ (04). (AAC 9221584 ProQuest).

North Carolina University, Greensboro, School of Education: SERVE: Southeastern Regional Vision for Education. (1993, October). Leadership for Collaboration: Participants Workbook. Washington, D.C.: Office of Educational Research and Improvement (ED).

O' Connor, Rochelle. (1983). Tracking the Strategic Plan: A Research Report from the Conference Board. New York: The Conference Board, Inc. 
Ozembloski, Lloyd William. (1994). The Process of Educational Change: A SchoolBased Management Initiative in Two Western Canadian Public School Districts. Dissertation Abstracts International 56 (08A). (AAI NN98384 FirstSearch).

Papke-Shields, Karen Elizabeth. (1997). Strategic Manufacturing Planning: Examining the Relationship Between Planning System Design, Manufacturing Context, and Planning Effectiveness. Dissertation Abstracts International 58 (03A). (AAG 9726777 FirstSearch)

Park, John Ellis. (1997). A Case Study Analysis of Strategic Planning in a Continuing Higher Education Organization (Continuing Education). Dissertation Abstracts International 58 (05A). (AAG 9732347 FirstSearch).

Peterson, Mark. (1995). Harnessing the Power of Vision, Ten Steps to Creating a Strategic Vision and Action Plan for Your Community. Preparing Your Community for the 21st Century Series.

Raney, David Livingston. (1995). Educating National Guard Leaders in Planning for Alternative Futures: From the Fall of the Wall Through the Desert Storm and Its Aftermath (Berlin Wall, Persian Gulf War). Dissertation Abstracts International 57 (02A). (AAI 9616225 FirstSearch).

Roberts, Carolyn Shannon. (1997). Leading Change to Create the Future: A Comparative Case Study of NASA and Xerox (National Aeronautics and Space Administration, Xerox Corporation, Leadership, Management). Dissertation Abstracts International 58 (05A). (AAG 9733127 FirstSearch).

Rusch, Edith A. (1992). Strategic Planning: Looking through the Lens of Foucault.

Schrader, David Alan. (1995). Toward the Environmentally Sustainable Corporation: The Challenges of Implementing Change. Dissertation Abstracts International 56 (06A). (AAI 9534542 FirstSearch).

Simon, Herbert A. (1965). Administrative Behavior. New York: The Free Press.

Singer, Alan E. (1996). Strategy as Rationality. Aldershot, England: Avebury, Ashgate Publishing Ltd.

Sloma, Richard S. (1984). No-Nonsense Planning. New York: The Free Press.

Snodgrass, Billy Bioten. (1993, May). The Degree of Usage of Strategic Planning in Tennessee School Systems. Dissertation Abstracts International 53 (11). (AAC 9308917 ProQuest). 
Snyder, Lois Bruner. (1997). The Impact of Strategic Planning on Student Assessment and Related Staff Development in Phase I School Districts in Pennsylvania. Dissertation Abstracts International 58 (04A). (AAG 9730851 FirstSearch).

Spivey, Norma Green. (1993, June). Administrative Readiness for and Engagement in Strategic Planning for Georgia's Technical Institutes. Dissertation Abstracts International 53 (12). (AAC 9312164 ProQuest).

Steele, Jay Francis, Jr. (1995, July). Strategic Plan Implementation for Small Denominational Colleges: A Case Study. Dissertation Abstracts International 56 (01). (AAC 9512721 ProQuest).

Steiner, George A. (1979). Strategic Planning: What Every Manager Must Know. New York: The Free Press, MacMillan.

Stone, Susan C. (1993). Shaping Strategy: Independent School Planning in the '90's.

Stone, Susan C. (1987). Strategic Planning for Independent Schools. Boston, Mass: N.A.I.S.

Summerbridge National Project. (1994). Teaching At Summerbridge. 1994 Handbook. San Francisco, CA: Author.

Talbot, Sue H. (1992). Strategic Planning: A Case Study (Lead Project, Indiana, School Reform). Dissertation Abstracts International 53 (05). (AAC 9228013 ProQuest).

Teran, Ralph. (1997). A Case Study of Strategic Planning in a Large Urban School District (Urban Education). Dissertation Abstracts International 58 (04A). (AAG 9730264 FirstSearch).

Thulare, Senyane Moses. (1992). Strategic Planning as a Part of the Managerial Task of a School Principal. Dissertation Abstracts International 54 (05). (NA).

Tse, Lettice Hung. (1996). A Responsive Corporate Information Model (Strategic Managment). Dissertation Abstracts International 58 (05A). (AAGNN18121 FirstSearch).

Valadez-Ortiz, Gustavo Rosenber. (1994). Administrative Perceptions of Effective Strategic Planning at Two California Community Colleges. Dissertation Abstracts International, 55 (05). (AAC 9426934 ProQuest).

VanDenAssem, David John. (1997). Gaetz Lakes Sanctuary Management Plan (Alberta). 
Vincent, Troy Jude. (1993, May). School District Improvement Through Strategic Planning; A Case Study (Des Moines Public Schools, Iowa). Dissertation Abstracts International 53 (11). (AAC 9234859 ProQuest).

Williams, Dennis Richard. (1992). Perspectives on Strategic Planning in Durham County Schools (Planning Process, North Carolina). Dissertation Abstracts International 53 (07). (AAC 9234929 ProQuest).

Wishnia, Gracie Spitzer. (1996). Adult Day Cares and Public Policy: A Strategic Plan for the Louisville Metropolitan Area (Kentucky). Dissertation Abstracts International 57 (10A). (AAG 9709457 FirstSearch). 
TITLE: $\quad$ Do Christian Schools Implement Long-Range Plans?

AUTHOR: DeGeorge, Steven L.

INSTITUTION: West Virginia University

ADVISER: Chair: Ernest R. Goeres

DESCRIPTORS: Education, Administration, Christian School, Planning

ABSTRACT: The purpose of this study was to examine long-range plans of schools accredited by the Association of Christian Schools International (ACSI) to determine whether evidence of implementation is present in administrators' job descriptions and evaluation documents.

Data were gathered through the use of a survey and by the collection and comparison of long-range plans, administrators' job descriptions, and evaluation documents. A second survey of board chairs was taken to determine the acceptance of the rational planning model presented and their attitudes toward implementation.

Thirty-two schools participated in the study, in which major points of the long-range plans were listed on a chart. Comparative statements from both administrators' job descriptions and evaluation documents were listed in parallel columns in order to show potential relationships between planning and implementation.

Eighty-seven percent of the documents studied contained comparative language indicating a positive correlation between planning and implementation. However, the comparative language tended to be more general than specific.

One case allowed for direct comparison by leaving blanks on the evaluation document to be filled in by the evaluator.

The conclusion of this study is that based on the comparative language in the documents, there is a clear acceptance of the rational planning model and a clear intention to have the plan implemented. However, further studies should explore the actual results of that intention to implement. 